KERESZTÚRI JUDIT LILLA

HÁLÓZATOK AZ EGÉSZSÉGÜGYBEN 
Befektetések és Vállalati Pénzügy Tanszék

Témavezető: Lublóy Ágnes Ph. D., egyetemi docens

Copyright ${ }^{\circledR}$ Keresztúri Judit Lilla 
BUDAPESTI CORVINUS EGYETEM

GAZDÁLKODÁSTANI DOKTORI ISKOLA

\section{HÁLÓZATOK AZ EGÉSZSÉGÜGYBEN}

DOKTORI ÉRTEKEZÉS

Keresztúri Judit Lilla

Budapest, 2016 



\section{TARTALOMJEGYZÉK}

KÖSZÖNETNYILVÁNÍTÁS 9

BEVEZETÉS. 10

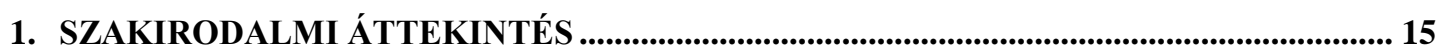

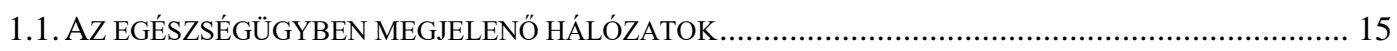

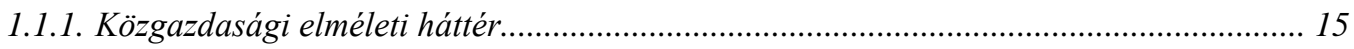

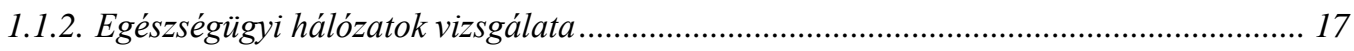

1.1.3. Transzmissziós hálózatok ........................................................................................... 19

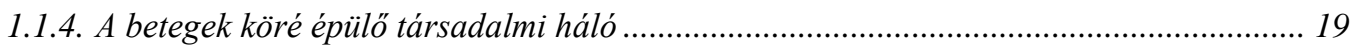

1.1.5. Az egészségügyi rendszeren belüli hálózatok .............................................................. 21

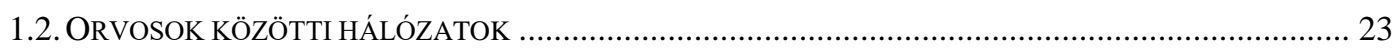

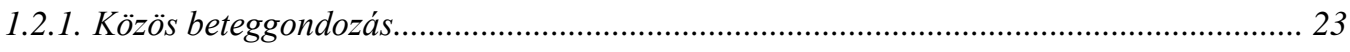

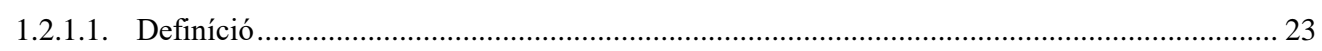

1.2.1.2. A közös beteggondozás megjelenési formái ..................................................................... 24

1.2.1.3. Közös beteggondozás a szakellátásban Magyarországon .................................................. 26

1.2.1.4. A közös beteggondozás előnyei és kihívásai .................................................................. 28

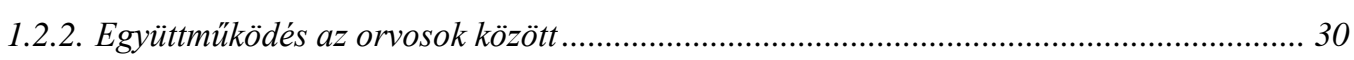

1.2.2.1. Kvalitatív módszertant alkalmazó kutatások az együttmüködések vizsgálatára .................... 31

1.2.2.2. Kvantitatív módszertant alkalmazó kutatások az együttmüködések vizsgálatára ................... 32

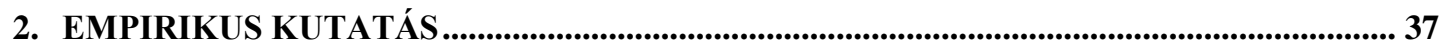

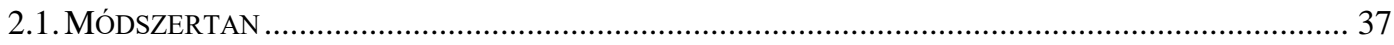

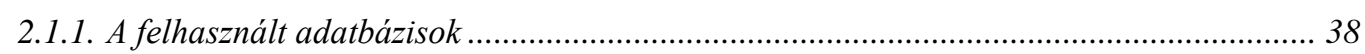

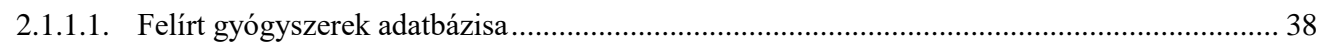

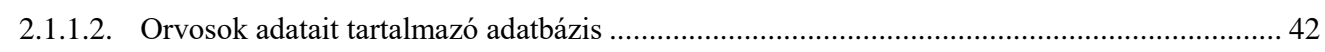

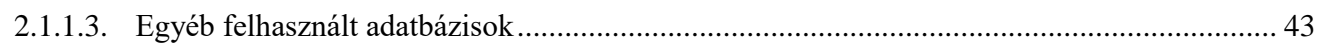

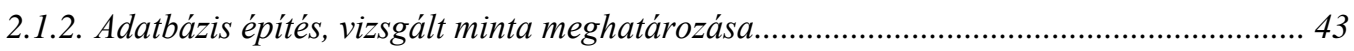

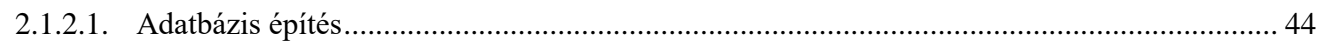

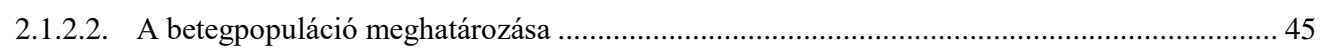

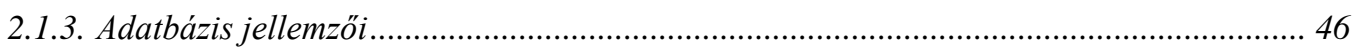

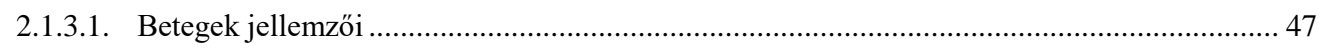

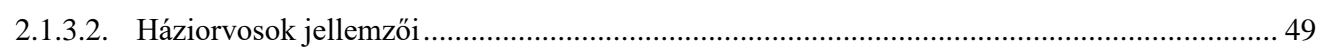

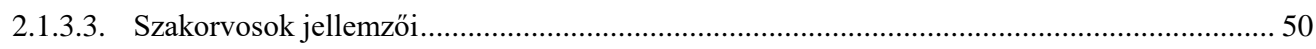

2.1.4. Háziorvosok és szakorvosok együttmüködési struktúrájának jellemzése......................... 52

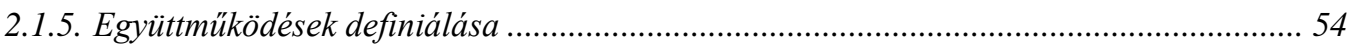

2.1.5.1. A szoros és gyenge kapcsolatok definíciója ........................................................................ 55

2.1.5.2. Koncentrált és nem koncentrált beutalási struktúrával rendelkező háziorvosok definíciója ... 57

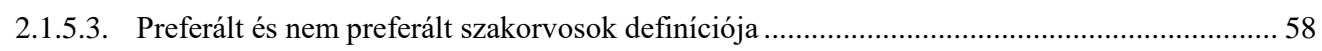

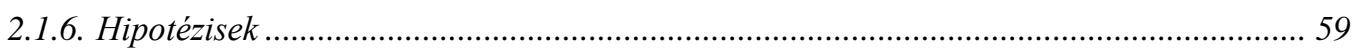

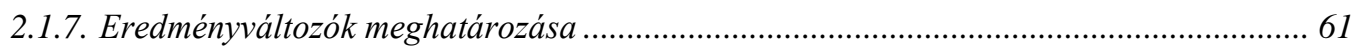




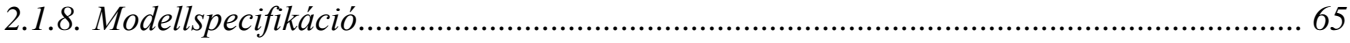

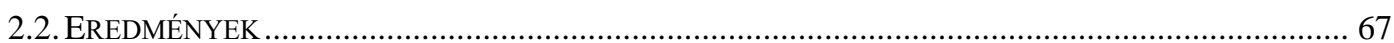

2.2.1. Betegek egészségi állapota és gyógyszerköltsége meghatározása szoros és gyenge

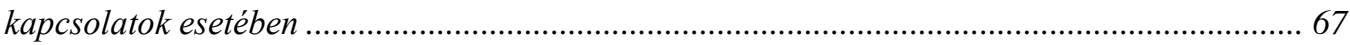

2.2.2. Szoros és gyenge kapcsolatok jellemzői ....................................................................... 74

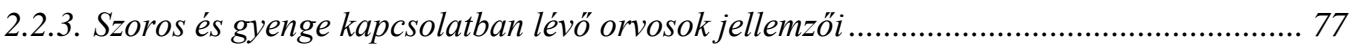

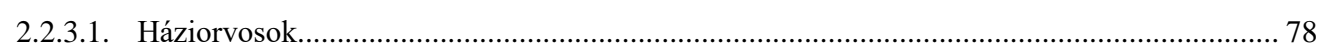

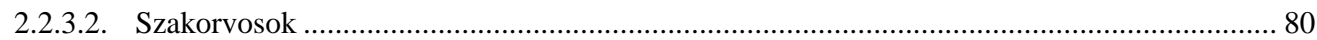

2.2.4. Kis és közepes méretü települések vizsgálata ............................................................. 82

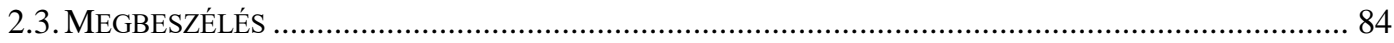

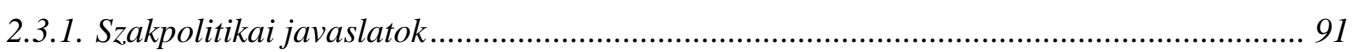

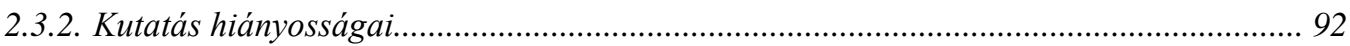

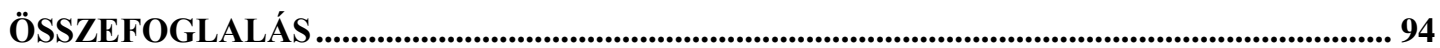

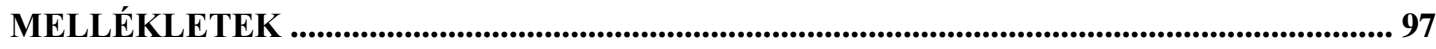

HIVATKOZÁSOK JEGYZÉKE ............................................................................................. 101

A TÉMAKÖRREL KAPCSOLATOS SAJÁT PUBLIKÁCIÓK JEGYZÉKE............................ 115 


\section{ÁBRÁK JEGYZÉKE}

1. ÁBRA - EGÉSZSÉGÜGYBEN FELFEDEZHETŐ HÁLÓZATOK CSOPORTOSÍTÁSA ........................................ 18

2. ÁBRA - SZOCIÁLIS HÁLÓZATOK MEGJELENÉSE AZ EGÉSZSÉGÜGYBEN …………………………..... 20

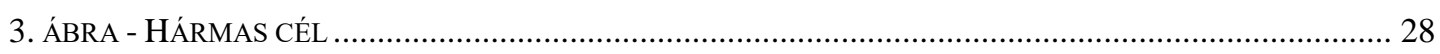

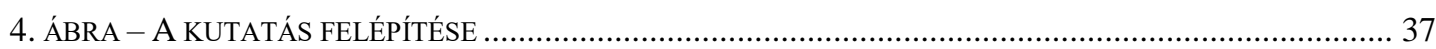

5. ÁBRA - HÁZIORVOSOK NEMEK SZERINT ÖSSZETÉTELÉNEK ÖSSZEHASONLÍTÁSA A DOKTORINFO KFT.

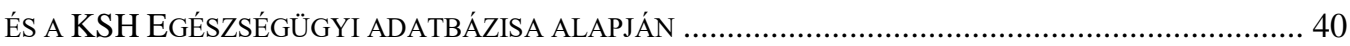

6. ÁBRA - HÁZIORVOSOK RÉGIÓK SZERINTI ÖSSZETÉTELÉNEK ÖSSZEHASONLÍTÁSA A DOKTORINFO KFT.

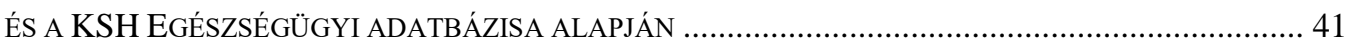

7. ÁBRA - HÁZIORVOSOK TELEPÜLÉS TÍPUS SZERINTI ÖSSZETÉTELÉNEK ÖSSZEHASONLÍTÁSA A DOKTORINFO KFT. ÉS A KSH EGÉSZSÉGÜGYI ADATBÁZISA ALAPJÁN ……………………......... 41

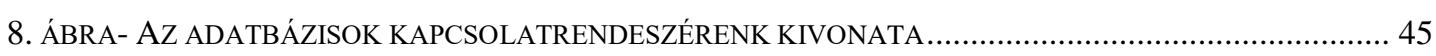

9. ÁBRA - A HÁZIORVOSOK ÉS A SZAKORVOSOK HÁLÓZATI STRUKTÚRÁJA …………………………........ 53

10. ÁBRA - EGY HÁZIORVOSRA JUTÓ SZAKORVOSOK SZÁMA............................................................ 53

11. ÁBRA - A HÁZIORVOSI-SZAKORVOSI KAPCSOLATOK KÖZÖSEN GONDOZOTT BETEGEK SZÁMA SZERINTI ELOSZLÁSA …………………………………….............................................. 54

12. ÁBRA - SZOROS ÉS GYENGE KAPCSOLATOK HÁROM HÁZIORVOS PÉLDÁJÁN KERESZTÜL ................... 57 


\section{TÁBLÁZATOK JEGYZÉKE}

1. TÁBLÁZAT - KÖZÖS BETEGGONDOZÁS ELŐNYEI ÉS KIHIVAÁSAI . 29

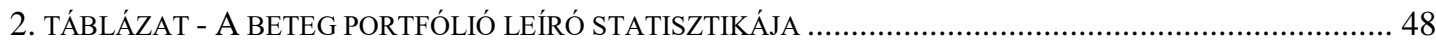

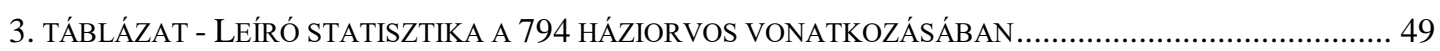

4. TÁBLÁZAT - LEÍRÓ STATISZTIKA A 318 SZAKORVOS VONATKOZÁSÁBAN …………………………..... 51

5. TÁBLÁZAT - SZOROS ÉS GYENGE KAPCSOLAT MEGHATÁROZÁSÁNAK SZEMLÉLTETÉSE ....................... 56

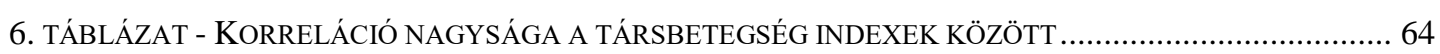

7. TÁBLÁZAT - A BETEGEK JELLEMZÖI A SZOROS ILLETVE A GYENGE HÁZIORVOSI-SZAKORVOSI

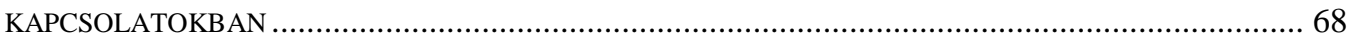

8. TÁBLÁZAT - A SZOROS ÉS GYENGE HÁZIORVOSI-SZAKORVOSI KAPCSOLATOK EREDMÉNYVÁLTOZÓK MENTÉN TÖRTÉNŐ JELLEMZÉSE 69

9. TÁBLÁZAT - ÉRZÉKENYSÉG VIZSGÁLAT A SZOROS ÉS GYENGE HÁZIORVOSI-SZAKORVOSI KAPCSOLATOK EGÉSZSÉGI ÁLLAPOT MENTÉN TÖRTÉNŐ JELLEMZÉSÉRE 70

10. TÁBLÁZAT- ÉRZÉKENYSÉG ÉS ROBOSSZTUSSÁG VIZSGÁLAT A SZOROS ÉS GYENGE HÁZIORVOSISZAKORVOSI KAPCSOLATOK GYÓGYSZERKÖLTSÉG MENTÉN TÖRTÉNŐ JELLEMZÉSÉRE ................. 71

11. TÁBLÁZAT - TÖBBVÁLTOZÓS REGRESSZIÓ A BETEGEK GYÓGYSZERKÖLTSÉGÉRE . .73

12. TÁBLÁZAT - SZOROS ÉS GYENGE HÁZIORVOSI-SZAKORVOSI KAPCSOLATBAN LÉVÖ ORVOSOK AZONOSSÁGA/KÜLÖNBÖZÖSÉGE .76

13. TÁBLÁZAT - A KONCENTRÁLT ÉS NEM KONCENTRÁLT BEUTALÁSI STRUKTÚRÁVAL RENDELKEZŐ HÁZIORVOSOK ÖSSZEHASONLÍTÁSA

14. TÁBLÁZAT - A PREFERÁLT ÉS A NEM PREFERÁLT SZAKORVOSOK JELLEMZÖINEK ÖSSZEHASONLÍTÁSA

15. TÁBLÁZAT - KIS ÉS KÖZEPES MÉRETỦ TELEPÜLÉSEN DOLGOZÓ HÁZIORVOSOK BETEGEIRE VONATKOZÓ EGÉSZSÉGI ÁLLAPOT ÉS GYÓGYSZERKÖLTSÉG ÖSSZEHASONLÍTÁSA 


\section{KÖSZÖNETNYILVÁNÍTÁS}

A köszönetnyilvánítás megírása az egyik legnehezebb részévé vált a dolgozatomnak, mert pontosan az az ember nem fogja tudni elolvasni a disszertációmat, akinek a legtöbbet köszönhetek: édesapám.

Nagyon köszönöm témavezetőmnek, Dr. Lublóy Ágnesnek, azt a sok segítséget, amit nyújtott és a közös munkát, amelyben részt vehettem az utóbbi években. Együttmüködésünk során személyében egy olyan embert ismerhettem meg, aki mind a szakmai, mind a magánéletben pozitív példa számomra.

Köszönettel tartozom a Befektetések és Vállalati Pénzügy Tanszéknek, ahol egy remek csapat tagja lehetek. Az inspiráló közösség és a kitünő hangulat jelentősen hozzájárult ahhoz, hogy ez a disszertáció megszülethessen. Különösen hálás vagyok Dr. Berlinger Edinának és Dr. Száz Jánosnak a témaválasztáshoz vezető rögös úton nyújtott segítségéért, és azért, hogy részese lehetek az általuk kialakított szakmai közösségnek. Köszönet tanszéki szobatársaimnak, akik mindig segítettek, bíztattak, ha elakadtam, és saját kutatásaikkal inspiráltak.

Köszönöm édesanyámnak, valamint Sári Tamásnak, Sáriné dr. Simkó Ágnesnek, Török Szilárdnak, Bodák Zoltánnak, és Baji Petrának a Ph.D. tanulmányaim alatt nyújtott folyamatos támogatást, segítséget. 


\section{Bevezetés ${ }^{1}$}

„People are interconnected,

and so their health is interconnected."

(Smith-Christakis [2008], pp. 405.)

Világunk hálózatok komplex rendszeréből tevődik össze, mely rendszer egyaránt megtalálható az emberi test elemi sejtjein belül, vagy éppen az általunk építetett univerzumban is. Léteznek olyan elméletek is, amelyek az emberek közötti kapcsolatokat is egy nagy társadalmi hálózat részeként értelmezik. Így a magánéletünkben, a szakmai életünkben is kialakulnak körülöttünk társadalmi hálózatok. Az ember kezdeti felismerése, miszerint együtt hatékonyabban képes megvalósítani céljait, létrehozta az együttmüködés intézményét, mely jelenség kibontakozása óhatatlanul személyek közötti hálózatokat hozott létre. Így társadalmi hálózatok rendszere megtalálható a közigazgatás egészében és részegységeiben, a gazdasági szervezetek és azok munkavállalóinak kapcsolataiban egyaránt. De hálózatok alkotják például az egészségügyben tevékenykedő szakemberek együttműködésének rendszerét és a betegekkel, valamint azok hozzátartozóival való érintkezésüket is. Disszertációmban olyan kapcsolatrendszerekkel foglalkozom, amelyek az orvosok közötti hálózatban meghatározóak.

$\mathrm{Az}$ egészségügyben müködő kapcsolatok egy rendkívül összetett és szerteágazó hálózatot alkotnak. Mind a betegek, mind a szakemberek, mind az egészségügyi intézmények között számos kapcsolódás alakulhat ki, amelyek a rendszer mélységét és integritását fokozzák. Annak érdekében, hogy alaposabban el tudjak mélyülni egy adott hálózat vizsgálatában, disszertációmban a kutatási irányt le kellett szúkíteni egy részterületre, mivel a teljes rendszer átfogó tanulmányozása e dolgozat terjedelmi kereteit meghaladná.

\footnotetext{
${ }^{1}$ Jelen disszertáció Keresztúri [2016], Lublóy és szerzőtársai [2016a], Lublóy és szerzőtársai [2016b], Lublóy és szerzőtársai [2016c] publikációkra épül.
} 
Disszertációmban a háziorvosok és szakorvosok közötti azon szakmai hálózatok müködését elemzem, melyben az orvosok közötti kapcsolat a közös beteggondozás során alakul ki. Vizsgálatom tárgya az, hogy vajon milyen hatással van ez a hálózat a betegek egészségi állapotára és gyógyszerköltségére.

A kutatási kérdés erőssége a felhasznált adatokban rejlik. A közös beteggondozás során azonosítottam azon formális együttmüködéseket a háziorvosok és a szakorvosok között, amelyek a beteg szakorvoshoz történő beutalásán, illetve a gyógyszerek utánírása ${ }^{2}$ révén valósulnak meg. Az orvosok közötti kapcsolat szorosságát a közösen gondozott betegek száma mentén határozom meg, ezeket a szakmai kapcsolatokat receptadatok alapján azonosítottam. Az adatbázisnak köszönhetően az adatbázisban szereplő orvosok közötti valamennyi kapcsolat feltérképezhető.

A háziorvosok receptadatainak segítségével lehetőség adódik a háziorvosok és a szakorvosok közötti formális hálózatok feltárására, elemzésére. Kutatásom során arra a kérdésre keresem a választ, hogy vajon az orvosok közötti kapcsolat minőségének a hatékony együttmüködésen és kommunikáción keresztül - van-e hatása az ellátásra.

A kutatásom során először azt vizsgálom, hogy vajon az egymással szorosan együttmüködő háziorvosok és szakorvosok - a betegek egészségi állapotának legalább azonos szintje mellett - képesek-e a gyógyszerköltséget csökkenteni, ezáltal a gyógyszerkasszát mérsékelni. Ha a betegenkénti gyógyszerkiadás - legalább azonos betegállapot feltételezése mellett - szoros háziorvosi-szakorvosi kapcsolatokban alacsonyabbnak bizonyul, akkor a szoros kapcsolatok létrejöttének támogatása valamennyi érintett érdekében áll. A fent leírtaknak megfelelően az első két következőkben megfogalmazott - hipotézisem együttes vizsgálata szükséges:

\footnotetext{
2 A közös beteggondozás keretében a háziorvos a szakorvoshoz beutalja a beteget; a szakorvos azonosítja a beteg számára a megfelelő terápiás készítményeket, amelyeket azt követően a háziorvos a szakorvosi javaslat szerint rendszeresen felír a beteg számára. A folyamatnak ez a része a gyógyszer utánírás.
} 


\section{H1: A szoros háziorvosi-szakorvosi kapcsolatban kezelt betegek egészségi állapota jobb.}

\section{H2: A szoros háziorvosi-szakorvosi kapcsolatban kezelt betegek gyógyszerkiadása alacsonyabb.}

A kutatásom újdonságtartalma nemcsak abban nyilvánul meg, hogy Európában ezen kérdések vizsgálatára ez idáig még nem került sor kvantitatív módszertan alkalmazásával, hanem abban is, hogy a nemzetközi szakirodalomban a két kérdés együttes megválaszolása sem fordult még elő.

Az első hipotézisre vonatkozóan korábban már végeztek kutatásokat, így az Amerikai Egyesült Államok vonatkozásában Barnett és szerzőtársai [2012], valamint Pollack és szerzőtársai [2013] tanulmányukban bebizonyították, hogy amennyiben egy adott orvos kevés másik orvossal gondoz közösen egy beteget, úgy az a beteg jobb egészségi állapotát eredményezi, vélhetően a szakmai jellegü információk hatékonyabb kezelése és a beteggondozás folyamatának könnyebb menedzselése miatt. Ezt a nézőpontot támasztja alá Lemieux és szerzőtársainak [2006] valamint Bosch és szerzőtársainak [2009] szisztematikus irodalom feldolgozása is, amelyben a szerzők megállapítják, hogy az orvosok közötti jó csapatmunka kedvezőbb klinikai teljesítménnyel és a betegek jobb egészségi állapotával jár együtt. Összességében elmondható, hogy csak Európán kívül készült még csak hasonló kutatás, de más országra/egészségügyi rendszerre még nem. Az én kutatási kérdésem megválaszolásához Pollack és szerzőtársai [2013] kutatása áll a legközelebb. Fontos megjegyezni, hogy az Európán kívül elvégzett kutatások eredményei nem transzferálhatóak át hazánkra az egészségügyi rendszerek különbözőségei miatt, de ezen kutatások által alkalmazott módszertan jó kiindulási pontot jelenthet az európai kutatásoknak.

A második hipotézisem alapját azon feltételezés képezi, miszerint ha az orvosok több beteget gondoznak közösen, úgy az alacsonyabb felmerülő gyógyszerköltséget eredményez. A cukorbetegség kezelését vizsgálva Walraven és szerzőtársai [2010] szisztematikus irodalom feldolgozásukban kimutatták, hogy az egészségügyi ellátás jobb koordinációja az egészségügyi szolgáltatások igénybevételének alacsonyabb szintjét eredményezi, különös tekintettel a kórházi és sürgősségi ellátásra. Barnett és szerzőtársai [2012], valamint Pollack és szerzőtársai [2013] azt igazolták, hogy azon 
betegek ellátási költsége alacsonyabb, akiknek orvosai egyszerre több beteget gondoznak közösen, vélhetően az orvosok közötti hatékonyabb együttmüködés miatt. Az ellátási költségek mérséklése fontos tényező, hiszen az egészségügyi kiadásokon belül a gyógyszerkiadás meghatározó szerepet játszik, például a cukorbetegség esetén az ellátás teljes költségének több mint 20\%-át teszi ki (Pollack és szerzőtársai [2013]).

Ha a szoros kapcsolatban kezelt betegek egészségi állapota alacsonyabb gyógyszerköltség mellett jobb vagy legalább azonos, akkor fontos megérteni, hogy milyen tényezők, orvos jellemzők állnak a kedvező hatások mögött. Megértésük ugyanis elősegítheti az egészségpolitikai stratégiát formálók számára olyan ajánlások megfogalmazását, amelyek ezeknek az összefüggéseknek, hálózatoknak az erősödését, kialakulását segítik elő.

Az együttmüködő orvosok közötti kapcsolat jobb megértése céljából indokolt azt megvizsgálni, hogy a közös beteggondozás hasonló jellemzőkkel rendelkező háziorvosok és szakorvosok között jön-e létre. Emellett szükséges annak felmérése is, hogy mennyiben térnek el a koncentrált beutalási struktúrával rendelkező háziorvosok jellemzői a nem koncentrált beutalási struktúrával rendelkező háziorvosokétól, és a preferált szakorvosok jellemzői a nem preferált szakorvosok jellemzőitől. Előzetesen azt az eredményt várom ezektől a vizsgálatoktól, hogy jelentős eltéréseket mutatnak a háziorvosok és a szakorvosok közötti kapcsolatok, és ez alapján lehet olyan szakpolitikai ajánlásokat adni, amelyek révén a jobb háziorvosi-szakorvosi együttmüködés következtében alacsonyabb gyógyszerköltségü ellátás tud megvalósulni. Az említett gondolatmenet nyomán a következő hipotézisek felállítása és vizsgálata szükséges:

\section{H3: A szoros kapcsolatban álló orvosok hasonlítanak egymásra (homofília).}

H4a: A koncentrált beutalási struktúrával rendelkező háziorvosok jellemzőik alapján elkülöníthetőek a nem koncentrált beutalási struktúrával rendelkező háziorvosoktól.

H4b: A preferált szakorvosok jellemzőik alapján elkülöníthetőek a nem preferált kapcsolatban álló szakorvosoktól. 
Kutatásom során arra a kérdésre keresem a választ, hogy vajon a háziorvosok és a szakorvosok közötti közös beteggondozás révén kialakuló kapcsolatok szorosságának milyen hatása van a beteg egészségi állapotára és a gyógyszerköltségre. Annak érdekében, hogy a betegek egészségi állapota kedvezően alakuljon és emellett a szükséges gyógyszerek összköltsége csökkenjen, indokolt annak elemzése, hogy vajon milyen háziorvosi-szakorvosi hálózat, illetve együttmúködés létrehozása hat ebbe az irányba. A kutatás gazdaságpolitikai jelentősége az, hogy ha megértjük háziorvosok és a szakorvosok közötti szakmai hálózatok müködését, akkor elősegíthetjük, támogathatjuk ezeket az orvos kapcsolatokat, és ez nagy valószínüséggel a betegek alacsonyabb gyógyszerköltséget eredményező ellátásához vezethet jobb vagy azonos minőség mellett, így ezeknek a kapcsolatoknak a megismerése az egész társadalom érdeke. 


\section{Szakirodalmi áttekintés}

A jelen fejezettel célom az, hogy bemutassam, hogyan kapcsolódik a kutatásom az eddigi szakirodalomhoz. A fejezet két részre tagolódik: az első alfejezetben ismertetem az egészségügyben megjelenő hálózatok típusait, és ezen belül kijelölöm disszertációm kutatási kérdésének irányát az egészségügyben megjelenő hálózatok vonatkozásában. A második alfejezetben a kutatási kérdésemhez kapcsolódóan az egészségügyi szervezetekben megjelenő hálózatok közül az orvosok közötti közös beteggondozás során kialakuló hálózatok témakörében megjelent kutatásokat ismertetem. A kapcsolódó szakirodalmat nem szisztematikus irodalom feldolgozás keretében mutatom be, hanem azt a módszert követtem, hogy a releváns cikkek hivatkozásjegyzékében szereplő publikációk mentén kerestem disszertációmba a szakirodalmat.

\subsection{Az egészségügyben megjelenő hálózatok}

Az egészségügyben számos hálózattal találkozhatunk: az orvosok, a betegek, a hozzátartozók, az egészségügyi intézmények, az állam, a gyógyszergyártók és az egészségügyi eszközöket előállító vállalatok között gyakorlatilag végleten számú hálózat létezik. Disszertációm jelen alfejezetének célja a kapcsolódó szakirodalom áttekintése: az egészségügyben megjelenő hálózatok kategorizálása, illetve az egyes kategóriákon belüli hálózattípusok bemutatása.

\subsubsection{Közgazdasági elméleti háttér}

Disszertációm közgazdasági elméleti hátterét egyrészt a szervezetközi kapcsolatok elmélete, másrészt a hálózatelmélet jelenti. A szervezetek közötti kapcsolatokat (interorganizational relations) középpontba állító írások fő célja az egyes gazdasági szereplők közötti együttműködések karakterisztikájának, mintázatának, eredetének, értelmének és következményeinek a megértése (Cropper és szerzőtársai [2008]). Az együttmüködés egy olyan folyamat, amelyben a szereplők közös célok elérésének érdekében együtt dolgoznak (Mattesich - Monsey [1992]). A folyamat eredményeképpen az együttműködő felek olyan eredményre jutnak, amelyet az egyes szereplők egyedül nem érhettek volna el; az együttműködés ezen pozitív hozadékát 
számos szakcikk igazolta (például, (Balakrishnan - Geunes [2004], Cropper és szerzőtársai [2008], Peng és szerzőtársai [2014], San Martín-Rodríguez és szerzőtársai [2005]). Disszertációmban a szervezeteket a háziorvosi illetve a szakorvosi ellátást biztosító egészségügyi intézmények jelentik, a szervezetek közötti kapcsolatok pedig a háziorvosok és a szakorvosok közötti szakmai együttmüködés lévén jönnek létre, ahol az együttmüködés célja a betegek gyógyítása.

A hálózatelmélet a szervezeti kutatásokban régóta fontos szerepet játszik. Borgatti és Foster [2003] részletesen áttekinti, hogy milyen elemzési irányok és konkrétan milyen kutatási területek köthetők a kapcsolathálózat-elemzés módszertanára építő szervezetkutatáshoz, amelyet magyarul Csizmadia és Grosz [2011] átfogó tanulmányában röviden ismertet. Borgatti és Foster [2003] nyolc olyan szervezetkutatási területet azonosít, ahol a hálózati paradigma érvényesítésre került: társadalmi tőke, csoportfolyamatok, kapcsolatok észlelése, tudás-menedzsment, vállalatok közti szövetségek, igazgatósági átfedések, szervezeti hálózatok, beágyazottság. A jelen - inkább mikro-orientációjú - kutatás tágabb kontextusát a beágyazottság és a kapcsolati tőke jelenti, hiszen azt vizsgálom, hogy az orvosok közötti együttműködés szorossága (beágyazottság) hatással van-e a gyógyszerkiadásra és a betegek egészségi állapotára (teljesítményben manifesztálódó kapcsolati tőke). A gazdaságszociológusokat régóta foglalkoztatja az összekapcsoltság gazdasági következménye, köztük a teljesítményre gyakorolt hatása. Smith-Doerr és Powell [2005] irodalom feldolgozása rávilágít arra, hogy a szervezetek közötti kapcsolatok egyszerre befolyásolják a gazdasági tevékenységek teljesítményét, a különböző elosztási mechanizmusokat és az információ terjedésének folyamatát. Smith-Doerr és Powell [2005] tipológiáját alkalmazva a disszertációmban vizsgált kutatási kérdés a kapcsolatok teljesítményre gyakorolt hatásának vizsgálatával foglalkozik. Csizmadia és Grosz [2011] kiemeli, hogy az empirikus kutatások többsége a kapcsolatok teljesítményre gyakorolt pozitív és negatív hatásait térképezi fel, ahogy azt a kutatásomban most én is teszem. 


\subsubsection{Egészségügyi hálózatok vizsgálata}

A hálózatelemzés egy olyan megközelítés mód, amely sajátos eszköztárával alkalmas arra, hogy feltárja, leírja, és megmagyarázza az egészségügyben kialakuló hálózatok struktúráját és folyamatait (Luke - Harris [2007]).

Varda és szerzőtársai [2012] szisztematikus irodalom feldolgozásukban arra jutottak, hogy az egészségügyi hálózatokat taglaló tanulmányok döntő többsége a hálózatok feltérképezése révén az együttmüködési struktúrákat elemzi. Az együttmüködések eredményének fényében a szerzők jellemzően ajánlásokat tudtak adni olyan egészségpolitikai stratégia alkotására, amelyek a társadalom számára pozitív hozadékkal járnak.

Luke - Harris [2007] a hálózatelemzés négy legfontosabb jellemzőjét az alábbi módon fogalmazták meg:

- $\quad$ ez egy olyan strukturális megközelités, amelynek középpontjában a szereplök közötti kapcsolatok állnak,

- empirikus adatokon alapszik,

- jellemzően matematikai és számítógépes modellek használatán alapul, és

- $\quad$ grafikus megjelenítésre ad lehetőséget.

Az egészségügyi hálózatok vizsgálatának újszerüsége a megközelítés módjában rejlik, nevezetesen abban, hogy az emberek egymás közötti kapcsolatait veszi górcső alá. A módszernek köszönhetően olyan összefüggéseket ismerhetünk meg, amelyek egyéb alkalmazások segítségével nem mutathatóak ki; néhány esetben már maga a hálózat topológiája is újdonságokat rejt. Ez a kutatási irány napjainkban nagyon kedvelt, és véleményem szerint még sok kutatási kérdés megválaszolásában fogják ezt a módszert alkalmazni a kutatók.

Disszertációmban Luke - Harris [2007] publikációja mentén mutatom be az egészségügyben megjelenő hálózatok csoportosítását. A szerzőpáros szerint három fö alhálózatot különböztethetünk meg: a transzmissziós hálózatokat, a betegek köré épülő társadalmi hálót és az egészségügyi rendszeren belüli hálózatokat (1. ábra). A transzmissziós hálózat két fő részre különíthető el: a betegségek terjedésére illetve az információ terjedésére. A betegek köré épülő társadalmi háló magában foglalja, hogy 
a betegek a kapcsolati tőkéjük által támogatást, segítséget kapnak a rokonaiktól és ismerőseiktől. Az egészségügyi rendszeren belüli hálózatok alatt az egészségügyi rendszer révén létrejövő hálózatokat kell érteni. Az egészségügyi rendszeren belüli hálózatok két fő csoportra oszthatók: az egészségügyi intézmények és a szakemberek közötti alhálózatokra (Luke - Harris [2007]) (1. ábra).

A három hálózat típus a kapcsolatok irányítottsága és a létrejövő kapcsolatok mentén jól elkülöníthető egymástól. A transzmissziós hálózatban egyértelmüen meghatározható az átadó és az átvevő, akik között rendszerint egyszeri alkalommal áramlik egy betegség vagy valamilyen információ, azaz egyirányú és egyszeri esemény hatására alakul ki ez a hálózat. A betegek köré épülö társadalmi hálóban ez nem határozható meg ilyen egyértelmủen, folyamatos gyakoriságú, változó irányú összetett kapcsolatrendszerről van itt szó; egyidőben egy résztvevő lehet átadó és átvevő is. Az egészségügyi rendszeren belüli hálózatok jellemzően felülről kialakított kapcsolatokat rejtenek; az egyének közötti kapcsolatok számos esetben nem az egyén választásának hatására jönnek létre.

\section{1. ábra - Egészségügyben felfedezhető hálózatok csoportosítása}
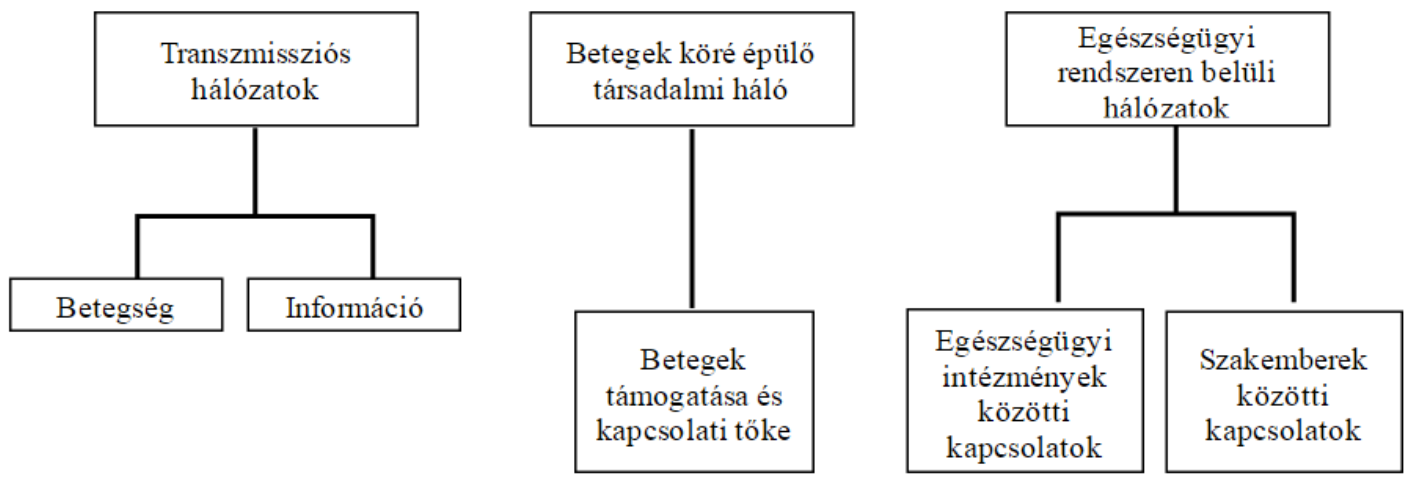

Forrás: Luke - Harris [2007] 5. ábrájának magyar nyelvü adaptációja alapján.

A következő alfejezetekben részletesen ismertetem az 1. ábrán látható alhálózatokat, azzal a céllal, hogy a saját kutatásomat el tudjam helyezni az egészségügyben fellelhető hálózatok között. 


\subsubsection{Transzmissziós hálózatok}

A transzmissziós hálózatok két részre különíthetőek el a korábban leírtaknak megfelelően: a betegségek illetve az információ terjedését felölelő hálózatokra. Az egészséggazdaságtanban megjelenő kutatások jellemzően a betegségek terjedése során kialakuló hálózatok vizsgálatával foglalkoznak.

A betegségek terjedését vizsgáló transzmissziós hálózatokra jellemző, hogy a kötés két ember között az a kórokozó, amellyel a fertőzés át tud terjedni a másik emberre (Friedman - Aral [2001]). A szakirodalomban számos kutatás, szisztematikus irodalom feldolgozás jelent meg a fertőző betegségek révén kialakuló hálózatok vizsgálatára, előrejelzésére (például Klovdahl és szerzőtársai [1994], Hufnagel és szerzőtársai [2004]).

A WHO [2007] a világ egészségügyi helyzetéröl készített 2007. évi jelentésével is felhívta a figyelmet a XXI. század globális közegészségügyi fenyegetéseire. Járvánnyal fenyegető betegségek az emberek felgyorsult mobilitásának köszönhetően rendkívül gyorsan tudnak kontinenseken át terjedni (WHO [2007]). Ha az elmúlt évekre tekintünk vissza, eszünkbe juthat az ebola, vagy a madárinfluenza fenyegetése, de ugyanilyen súlyos a helyzet a szexuális úton terjedő betegségek esetében is. Ezeknek a hálózatoknak a feltérképezése, előrejelzése az egész társadalom érdeke.

A disszertációmban én a transzmissziós hálózatok betegségekhez és információ terjedéshez kapcsolódó hatásával nem foglalkozom.

\subsubsection{A betegek köré épülő társadalmi háló}

Jelen alfejezetben a betegek köré épülő társadalmi hálót mutatom be, amely nélkül számos beteg esetében az egészségügyi rendszer nem, vagy csak igen magas ráfordítással, illetve jóval kisebb hatékonysággal tudna müködni.

Christakis [2004] kutatásában rávilágít arra, hogy ugyan a hálózati megközelítés fokozott figyelmet kap például a mérnökök, a biológusok, a szociológusok kutatásaiban, de az egészségügy és gyógyszertudományok területén még kevésbé épült be ez a szemléletmód. Az egészségügyi ellátásnak azonban nemcsak az egyénekre 
kellene fókuszálnia, hanem figyelembe kellene vennie az egyén társadalmi hálózatrendszerét is (Smith - Christakis [2008]).

A beteg társadalmi kapcsolatainak pozitív hatása van az egészségügyi rendszerre és a beteg állapotára is (2. ábra). A tradicionális megközelítésben az orvos a beteghez az egészségügyi rendszeren keresztül kapcsolódik, és a kezelés hatására közvetlen eredmények érhetők el a beteg egészségi állapotában, amelynek természetesen költség vonzata is van. A kiterjesztett modellben az orvos nemcsak a beteggel áll kapcsolatban, hanem közvetett módon a beteg szociális kapcsolatrendszerével is, azaz megjelenik a betegek köré épülö társadalmi háló és ennek jótékony hatása (Christakis [2004]). A beteg ismerősei köréből sokan tudnak segíteni az ellátásában, például a gyógyszerek kiváltásába illetve beszedésének ellenőrzésébe bármelyik családtag aktívan be tud kapcsolódni. A szomszéddal folytatott beszélgetések, közös séták is jótékony hatással lehetnek. Fontos kiemelni, hogy itt nemcsak egy krónikus idős betegre kell asszociálnunk, egy fiatal fekvőgipsszel rendelkezö betegnek is sokat tud segíteni a környezete a mindennapi boldogulásban.

\section{2. ábra - Szociális hálózatok megjelenése az egészségügyben}

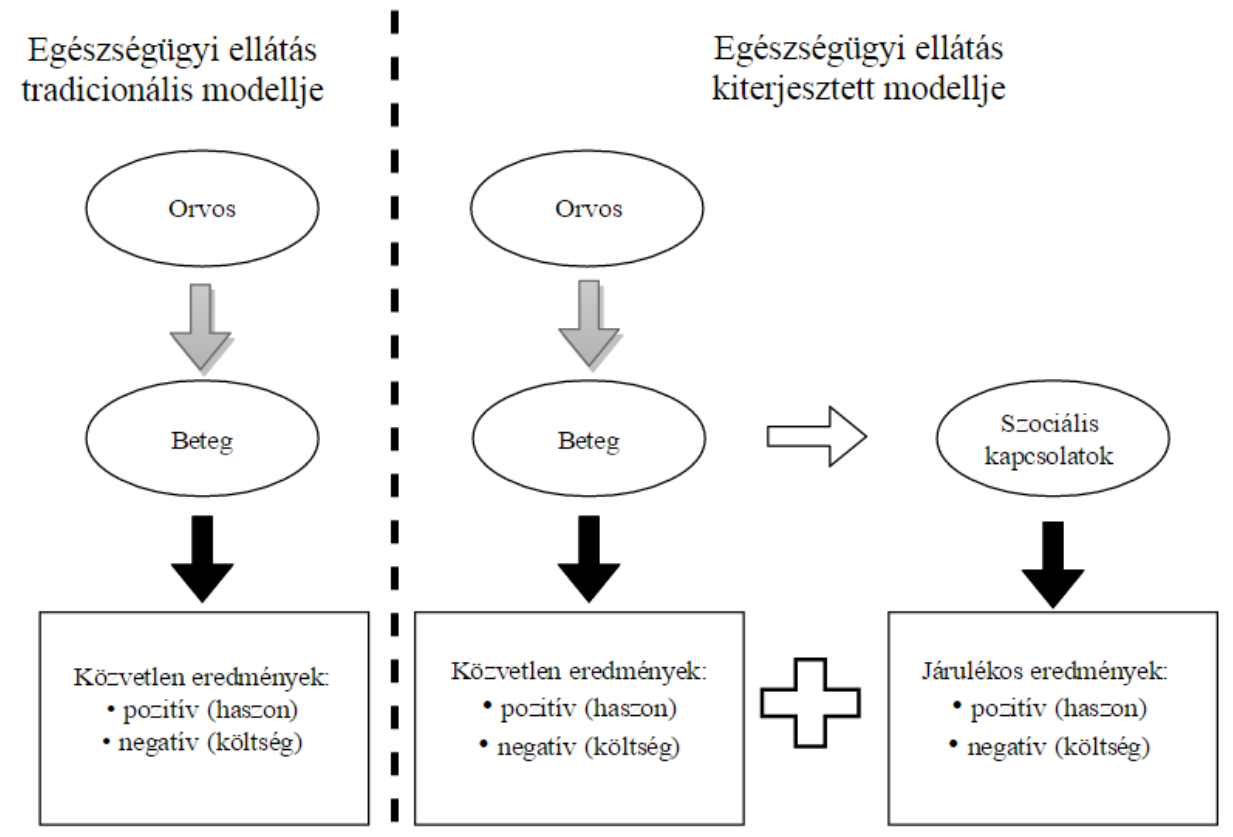

Forrás: Christakis [2004] 184. oldalon található ábrájának magyar nyelvü adaptációja.

Cammack - Byrne [2012] kutatásukban továbbgondolták a betegek köré épülő társadalmi háló szerepét a beteg ellátásban. Olyan ellátási modellt vázoltak fel, 
amelyben már az új technológiai innovációk is helyett kapnak. Christakis [2004] modelljéből kiindulva, véleményük szerint fontosak az olyan alkalmazások, amelyek képesek a betegek ellátása érdekében kezelni az egyén társadalmi kapcsolatait. Cammack - Byrne [2012] példaként bemutatnak egy szoftvert, amelyet úgy kell elképzelni, mintha egy közösségi oldal, egy dokumentumkezelő és egy napirend tervező közös metszete lenne. A szoftver úgy müködik, hogy például a program napirend tervező része jelez a nagymamának, hogy holnap orvoshoz kell mennie. Ezzel párhuzamosan a szoftver a hozzátartozók tudtára adja, hogy a nagymamát holnap orvoshoz kell vinni, akik látják az üzenetet, és tudnak rá reagálni. A szoftver dokumentumkezelő része pedig a legfrissebb leleteket, az otthoni tesztek eredményeit tudja kezelni és tárolni, illetve a megadott hozzátartozóknak akár betekintést is képes biztosítani.

Disszertációmban a betegek köré épülő társadalmi háló elemzésével nem foglalkozom.

\subsubsection{Az egészségügyi rendszeren belüli hálózatok}

Az egészségügyi rendszeren belül az intézmények között számos hálózat jön létre, nagyrészt a központosított betegáramlásnak köszönhetően. Kutatásomban én nem az intézmények közötti hálózatokkal foglalkozom, hanem az egyes egészségügyi intézményekben dolgozó szakemberek közötti kapcsolatokkal (1. ábra). A disszertációmban a közös beteggondozás révén a háziorvosok és a szakorvosok között kialakuló hálózatokat vizsgálom.

A szakirodalomban az egészségügyi rendszeren belüli hálózatok számos csoportosításával találkozhatunk. Chambers és szerzőtársai [2012] szisztematikus irodalom feldolgozásukban megkülönböztették az alapellátás, a járóbeteg ellátás, a fekvőbeteg ellátás, illetve az egyéb és vegyes ellátásban megjelenő hálózatokat. Kutatásukban arra jutottak, hogy az orvosok közötti társadalmi kapcsolatok kevésbé jelentek meg korábban az egészségügyi kutatásokban, mint az egyéb tényezők. A kutatók jellemzően leíró jellegűen mutatják be a különböző résztvevők közötti hálózatokat. Véleményem szerint a mélyebb tartalmi elemzés és a szakpolitikai javaslatok hiányának az lehet az oka, hogy ezeknek a hálózatoknak a kutatók korábban nem tulajdonítottak nagyobb jelentőséget. 
Ranmuthugala és szerzőtársai [2011] szisztematikus irodalom feldolgozásukban azt vizsgálták, hogy hogyan kommunikálnak egymással a különböző pozíciókban lévő szakemberek. A kutatók annak a vizsgálatára helyezték a hangsúlyt, hogy vajon a szakemberek hogyan osztják meg egymással a közös tudást, és ez a tudásmegosztás hogyan szolgálja a szervezet javát. Arra a megállapításra jutottak, hogy az egészségügyben a szakemberek közötti kommunikáció jelentősen eltér a különböző ellátási szinteken. A kutatók hangsúlyozták, hogy a jelenlegi egészségügyi rendszer fejlesztése érdekében fontos ezeknek a hálózatoknak, illetve a hálózatokban zajló folyamatoknak a jobb megértése és a hatékony hálózatok létrejöttének támogatása.

Cunningham és szerzőtársai [2012] egészségügyi hálózatokat taglaló szisztematikus irodalom feldolgozásukban három fö következtetést vontak le: egyrészt létfontosságú a szakmai hálózatok szerkezetének és jellemzőinek a megértése; másrészt fontos ezen hálózatok müködésének megismerése; harmadrészt pedig érdemes időt fektetni a szakmai kapcsolatok ápolásába, hiszen ez a befektetett idő megtérül majd az ellátásban. A kutatásuk rámutatott arra, hogy a hálózatok jobb megismerése elősegítheti a jobb ellátást.

Az előzőekben bemutatott három irodalom feldolgozás számos hasonlóságot mutat:

A kutatók egyrészt megállapítják, hogy az egészségügyi rendszerben annak összetettsége miatt számos szakmai hálózat alakul ki a szakemberek között. A különböző ellátási területeken ugyanakkor nagymértékben eltérnek ezek a hálózatok. Másrészt a kutatók egybehangzóan kimondták, hogy ezeknek a hálózatoknak pozitív hozadéka van az egészségügyi ellátás vonatkozásában. Harmadrészt a kutatók megállapították, hogy a korábbi szakirodalmi írások többsége jellemzően inkább a hálózatok leírására, bemutatására irányult, nem pedig mélyebb tartalmi elemzésére. Negyedrészt, a kutatók hangsúlyozták, hogy fontos lenne az egészségügyi rendszer egy-egy szegmensének hálózatelméleti módszerekkel történő mélyebb vizsgálata, a hálózatok leírása mellett a hálózatokban zajló folyamatok jobb megértése. Mindez lehetővé tenné olyan szakpolitikai ajánlások megfogalmazását, amelyek hozzájárulnának a hatékony egészségügyi ellátás létrejöttéhez.

Disszertációmban a felvázolt szakirodalmi ür betöltése érdekében arra vállalkozom, hogy megvizsgálom a magyarországi orvosok közötti hálózatokat. Dolgozatomban a 
háziorvosok és szakorvosok közötti, a közös beteggondozás révén kialakult kapcsolatokat fogom elemezni. Arra a kérdésre keresem a választ, hogy a háziorvosok és a szakorvosok között kialakuló szoros kapcsolatoknak van-e hatása a beteg egészségi állapotára és a gyógyszerköltségekre. A hálózatok leírásán túlmenően arra is kiterjesztem a kutatásomat, hogy az eredmények fényében szakpolitikai ajánlásokat fogalmazzak meg.

\subsection{Orvosok közötti hálózatok}

Jelen alfejezetben ismertetem a háziorvosok és szakorvosok közötti kapcsolatok elemzéséhez szükséges keretrendszert, nevezetesen a közös beteggondozást. Azon háziorvosi-szakorvosi kapcsolatok ugyanis, amelyeket vizsgálni fogok, a közös beteggondozás révén alakultak ki az orvosok között. Jelen alfejezet második felében bemutatom az empirikus kutatásomhoz legjobban kapcsolódó, a háziorvosok és a szakorvosok között létrejövő együttmüködési struktúrák vizsgálatával foglalkozó kutatásokat is.

\subsubsection{Közös beteggondozás}

Ebben a szakaszban először a közös beteggondozás definícióját adom meg (1.2.1.1. pont). Ezután a közös beteggondozás különböző megjelenési formáit (1.2.1.2. pont), illetve az elemzésre kerülő magyarországi rendszert ismertetem (1.2.1.3. pont). A szakasz végén kitérek a közös beteggondozás előnyeire és kihívásaira is.

\subsubsection{Definíció}

A szakirodalomban a közös beteggondozás (angolul: shared care) tágan értelmezett definícióját Moorehead [1995] fogalmazta meg:

„A közös beteggondozás olyan betegellátási módszer, amely épít az egészségügyi szakemberek szerteágazó szakértelmére és tudására, akik közös felelösséget vállalnak a beteg ellátásában. Ez azt is jelenti, hogy a szakemberek folyamatosan ellenőrzik és megosztják a beteg adatait, valamint a különböző tudományágak közötti tudást és szakértelmet.” (Moorehead [1995], 1985. old., fordította Keresztúri Judit Lilla) 
Hickman és szerzőtársai [1994] inkább a háziorvosok és a szakorvosok közötti közös beteggondozásra fókuszálva határozták meg ezt a fogalmat:

„A közös beteggondozás a háziorvosok és a szakorvosok együttes részvételét jelenti a krónikus betegek tervezett ellátásában, intenzív információ cserével, amely túlmutat a rutin beutalásokon és javaslatokon.” (Hickman és szerzőtársai [1994], 447-448. old., fordította Keresztúri Judit Lilla) A disszertációmban a továbbiakban az együttmüködések vizsgálatához Hickman és szerzőtársai [1994] definícióját veszem alapul.

A közös beteggondozás legföbb alapelve az, hogy a különböző szakterületen dolgozó szakemberek közösen vállalnak felelösséget a beteg ellátásáért, miközben a beteget a legjobb tudásuknak megfelelö ellátásban részesítik, és ennek következtében a szakterületek közötti szinergiákat is kihasználják. Hickman és szerzőtársai [1994] definíciójának érdekessége, hogy az ellátás minősége nem jelenik meg a megfogalmazásukban.

Az előzőekben bemutatott definíciókban ugyan szintén nem jelenik meg, de fontos kiemelni, hogy a közös beteggondozás rendszerének bevezetését követően legtöbbször a szakorvosok leterheltsége kisebb lesz, hiszen a rutin ellenőrzéseket, receptfelírásokat a háziorvosok végzik, ezzel csökkentve a járóbeteg és a fekvőbeteg ellátás leterheltségét. Ha valóban sikerül ezen ellátások igénybevételét mérsékelni, az az egészségügyi rendszer müködéséhez szükséges költségek csökkenését okozza (Greenhalgh [1994]).

\subsubsection{A közös beteggondozás megjelenési formái}

A közös beteggondozás az 1970-es évek elején már megjelent néhány angol településen. A cukorbetegek közös beteggondozását taglaló kutatásokat Greenhalgh [1994] két fő kategóriába csoportosította: a nem-randomizált és a randomizált betegcsoportokon alapuló kutatásokra. Az első randomizált betegcsoportokon alapuló kutatás az 1980-as években valósult meg. Számos esetben nem felülröl jött a közös beteggondozási rendszer kialakításának kezdeményezése, hanem például az 1970-as évek végén Sheffield-ben a diabetológus szakorvos kérésére a háziorvosok segítették a szakorvos munkáját a betegek rutin ellátásában. Chester-ben 1985-ben pilot 
projektként már elindult a betegek 100\%-os közös beteggondozásban történő ellátása. A kutatások jellemzően a betegek állapotának vizsgálatára irányultak: azt vizsgálták, hogy a közös beteggondozás keretében a betegek állapota hogyan alakult. A kutatások értelmében számos településen romlott a betegek állapota (például Cardiff, East Fife), sok településen nem jelentkezett állapot javulás (például Grampian, Wolverhampton), míg sok esetben javulást tapasztaltak (például Islington, Sydney) (Greenhalgh [1994]). Összességében elmondhatjuk, hogy a rendszer ebben az időszakban még számos hibát hordozott, de sok településen a rendszer kialakulásával/kialakításával az egészségügyi szakemberek elismerésre méltó eredményeket értek el a betegek egészségi állapotának javulásában.

A közös beteggondozás csoportosításának legelterjedtebb formája, hogy a betegek közös ellátásában résztvevő személyek munkahelye alapján határozzák meg a kategóriákat. A disszertációmban én White [2010] csoportosítása alapján mutatom be, hogy hogyan kategorizálhatjuk a közös beteggondozás egyes eseteit:

- közös beteggondozás az alapellátásban,

- közös beteggondozás a szakellátásban,

- $\quad$ közösségen alapuló közös beteggondozás.

Az alapellátáson belüli közös beteggondozás azt jelenti, hogy a háziorvos együttműködik az általános ápoló és/vagy szakápolóval (Smith - Campbell [2004]), vagy szakápolóval és egy multidiszciplináris csapattal (Vjrijhoef és szerzőtársai [2002], vagy a szülésszel, bábával (Lombardo - Golding [2003]). Magyarországon a háziorvosnak az asszisztens az alkalmazottja, így megkérdőjelezhető az együttmüködés fogalma. Fontos kiemelni Orosz [2001] véleményét, hogy hazánkban „hiányzik a háziorvosi ellátás és az alapellátáshoz tartozó más szolgálatok (a védőnők, iskolaorvosok és gyermekgyógyászati rendelések stb.) közötti együttmüködés, továbbá nem megfelelő az alapellátás és a szociális gondozás kapcsolata sem” (Orosz [2001] p. 204). A jobb együttmüködés kialakítására az alapellátás szereplöi között 
napjainkban is folynak hazánkban projektek (TÁMOP, svájci modell³) (Horváth [2015]).

A szakellátáson belüli közös beteggondozás esetén a háziorvos közösen látja el a betegeket a szakorvosokkal (Hobbs - Wilson [2004]) vagy a kórházzal, speciális klinikával (White [2001]). Ebben az esetben például a kórházban ellátják a beteget, de az utógondozásban, a beteg állapotának későbbi ellenőrzésében a háziorvos fontos szerepet tölt be. Hazánkban jelenleg ez a rendszer az egész országra kiterjedően müködik, és a betegeknek fontos a háziorvos felkeresése a leletekkel a további készítmények felíratása illetve a táppénz érdekében.

A közösségen alapuló közös beteggondozásnak az a lényege, hogy már nemcsak szakembereket vonnak be az adott egyén ápolásába, hanem a családot (Lindsay és szerzőtársai [1998]) illetve olyan szervezeteket is, amelyek jellemzően az otthoni betegápolást segítik elő (Andrews - Hood [2003]).

A csoportosításból láthatjuk, hogy a háziorvos nemcsak a szakorvos, vagy a kórházi ellátás munkáját segítheti, hanem saját feladatai ellátásához ő is kaphat segítséget a közös beteggondozás keretében. A TÁMOP és a svájci modell új dimenzióba helyezi az alapellátást. „A rizikómenedzsmentre, a kockázatkezelésre, valamint a népegészségügyi orientációra helyeződik a hangsúly” (Horváth [2015]).

Fontos kiemelni, hogy a háziorvosok munkája elképzelhetetlen a más szakterületeken dolgozó kollégáik együttmüködése nélkül. Disszertációm kutatási kérdésében a háziorvosok és a szakorvosok között kialakuló közös beteggondozást fogom elemezni, ezért a következő pontban részletesen bemutatom a hazai rendszer müködését.

\subsubsection{Közös beteggondozás a szakellátásban Magyarországon}

A magyar egészségügyi ellátás elsősorban adóból és a kötelező biztosítási járulékokból kerül finanszírozásra. Az egészségügyi ellátáshoz való hozzáférés egyetemes, a szolgáltatásokhoz való hozzáférés a lehető legszélesebb körben biztosított. Magyarországon egy központi hivatalos egészségbiztosítási szerv, az

\footnotetext{
${ }^{3}$ A svájci modell ismertetését részletesen lásd a Kiss [2016] disszertációjában.
} 
Országos Egészségbiztosítási Pénztár (továbbiakban OEP) természetbeni és pénzbeli ellátásokat nyújt a biztosítottaknak (OEP [2015]). ${ }^{4}$

Ma Magyarországon a krónikus betegek gondozását közösen végzi a háziorvos és a szakorvos. Korábban Magyarországon 1990-es évekig például a cukorbetegek kezelését a kórházakban végezték, amely rendkívül költséges volt, hiszen több napos bent fekvés keretében állították be a gyógyszereket és stabilizálták a beteg állapotát, valamint havonta/ háromhavonta újra felkereste a szakorvost a beteg, hogy számára a szakorvos felírja a beállított készítményeket.

Napjainkban „az általános járóbeteg-szakellátás a beteg folyamatos ellátását, gondozását végző orvos beutalása vagy a beteg jelentkezése alapján, szakorvos által végzett egyszeri, illetve alkalomszerű egészségügyi ellátás, továbbá fekvőbetegellátást nem igénylő krónikus betegség esetén a folyamatos szakorvosi gondozás" (OEP [2016]). A szakorvosok és a háziorvosok közötti ezen feladatmegosztás egyik oldalról csökkenti a szakorvosok terheltségét, hiszen a betegek így őket általában csak ritkábban keresik fel (félévente vagy évente), míg a másik oldalról növeli a háziorvosokét, hiszen a betegek őket a szakorvos által javasolt készítmény felírása miatt havonta/kéthavonta felkeresik. A háziorvosok a betegek havonkénti/kéthavonkénti látogatása révén felügyelni tudják a betegek egészségi állapotát; amennyiben abban jelentős romlás áll be, azaz vélhetően nem megfelelő a terápiás kezelés, akkor javasolni tudják a szakorvos újbóli felkeresését.

Főszabály szerint a háziorvosoknak az OEP által kijelölt legközelebbi járóbetegszakellátásra kell beutalniuk a betegeiket. „A beteget orvos választási jog illeti meg, ennek keretében joga van az egészségügyi intézmény munkarendje szerint a beteg ellátására beosztott orvos helyett másik orvost választani, amennyiben azt a biztosított egészségi állapota által indokolt ellátás szakmai tartalma és az ellátás sürgőssége nem zárja ki. Az orvosválasztást írásba kell foglalni, amit a biztosított, valamint a választott orvos is kézjegyével ellát" (OEP [2016]).

\footnotetext{
${ }^{4}$ Fontosnak tartom megjegyezni, hogy a 1312/2016. (VI. 13.) Korm. határozat 1. melléklete szerint az Országos Egészségbiztosítási Pénztár jogutódlással - az Emberi Erőforrások Minisztériumába történő beolvadással - megszünik, ennek határideje 2016. december 31.
} 


\subsubsection{A közös beteggondozás előnyei és kihívásai}

Berwick és szerzőtársai [2008] megfogalmazták azt a hármas célrendszert (angolul: triple aim), amelynek minden egészségügyi rendszer meg kell, hogy feleljen (3. ábra).

Az egészségügyi rendszerek fejlesztése, kialakítása során három célt kell szem elött tartani: fejleszteni az ellátás minőségét, javítani a társadalom egészségét, és csökkenteni az egy före jutó ellátás költségét. Fontos megjegyezni, hogy egyszerre kell az egymással összefüggő három célt figyelembe venni, és egy időben minden célnak teljesülnie kell a rendszer kialakítása/átalakítása során. A célok eléréséhez folyamatosan mérni kell a betegek egészségi állapotát, az ellátás minőségét és a felmerülő költségeket (Berwick és szerzőtársai [2008]).

\section{3. ábra - Hármas cél}

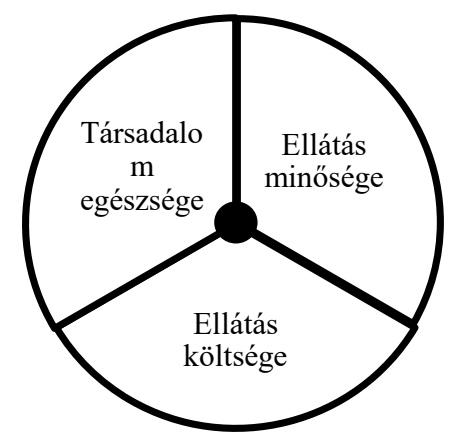

Forrás: Berwick és szerzőtársai [2008] alapján.

Az egészségpolitikusok napjainkban számos országban egyre nagyobb hangsúlyt helyeznek a háziorvosi ellátás és a szakellátás integrációjára, amellyel céljuk egy jobb és gördülékenyebb betegellátás biztosítása, az egészségügyi szakemberek közötti együttmüködés javítása, valamint a háziorvosi és szakorvosi ellátás közötti feladatmegosztás optimális egyensúlyának kialakítása. A háziorvosi és szakorvosi ellátás integrációjának eredményes megvalósulása pedig végső soron hozzájárulhat az egészségügyi kiadások csökkentéséhez. Az integráció egyik kulcseleme a krónikus betegségben szenvedő páciensek közös beteggondozásának megszervezése.

A közös beteggondozás amellett, hogy számos előnnyel rendelkezik, sok kihívást állít az egészségpolitikusok elé. Az 1. táblázatban Millar - Drasic [2005] szisztematikus irodalom áttekintésének az előnyöket és kihívásokat tartalmazó felsorolása látható. 


\section{1. táblázat - Közös beteggondozás előnyei és kihívásai}

\begin{tabular}{|l|l|}
\hline \multicolumn{1}{|c|}{ Elönyök } & \multicolumn{1}{|c|}{ Kihívások } \\
\hline - Az ellátási rendszer töredezettsége & - Hatalom és a státuszbeli különbségek a \\
csökken; azaz integráltabb és folyamatosabb & különböző egészségügyi ellátó szintek \\
lesz az ellátási rendszer. & között (pl. ápolók és háziorvosok, illetve \\
- A szükös erőforrások hatékonyabb & háziorvosok és szakorvosok között). \\
felhasználása és költséghatékonyabb ellátás. & - Fenyegetés a szakmai autonómiára és/ \\
- Szorosabb kapcsolat a különböző szintü & vagy munkakör hatályára. \\
ellátási rendszerek között. & - A háziorvosok finanszírozási ösztönzői \\
- Fejlettebb szintủ munkakapcsolatok. & nem megfelelőek. \\
- Elégedettség növekedése a betegek és az & - Elegendő személyzet az alapellátás \\
orvosok körében. & megvalósításához és irányításához. \\
- Növekszik a betegek hozzáférése az & Túlterhelt háziorvosok nem tudják \\
ellátáshoz. & megfelelően ellátni a közösen gondozott \\
& betegeket. \\
& - Limitált módszerek a közös beteggondozás \\
révén elért eredmények mérésére.
\end{tabular}

Forrás: Millar - Drasic [2005] 9. oldalán található táblázatának magyar nyelvủ adaptációja.

A közös beteggondozás rendszerének számos pozitív tulajdonsága van, de megfelelő ösztönzök nélkül kudarc is lehet belöle. A közös beteggondozás előnyei közül kiemelném, hogy ennek az ellátási módszernek a segítségével költséghatékonyabb egészségügyi rendszert lehet kialakítani. Ennek az ellátási módszernek további előnye, hogy szorosabb lehet a kapcsolat a különböző szintü ellátási rendszerek között, ha az orvosok közötti kommunikáció aktívabb. Az orvosok és betegek körében egyaránt elégedettség növekedést okozhat a rendszer kialakítása, hiszen a betegek jobb ellátásban részesülnek, míg a szakorvosok leterheltsége csökken. A közös beteggondozás azonban nem tud megfelelően működni, ha a háziorvosoknak nincs elegendő ideje a betegek közös ellátására, hiszen számukra ez a rendszer plusz leterheltséget generál. Fontos, hogy a közös felelösségvállalás keretében ne alakuljon ki pozícióharc a különböző szakterületen dolgozó orvosok között. A szakorvos úgy érezheti, hogy elveszíti a kontrollt a beteg egészségi állapota felett. A finanszírozási ösztönzők helyes meghatározása is kulcskérdés lehet a rendszer sikerességében, azaz például, ha egy orvos csak akkor kap költségtérítést, amikor a beteg őt felkeresi, akkor hiába vezetnek be új szoftvereket az orvosok közötti információáramlás segítésére az 
egészségügyi stratégiaalkotók, az orvos nem fogja megnézni az eredményeket, zárójelentéseket stb., csak akkor, amikor öt a beteg felkeresi. Végezetül pedig kiemelném a közös beteggondozás rendszerének azt a kihívását, hogy limitáltak a mérési módszerek, azaz nem állapítható meg pontosan, hogy a beteg állapota valójában hogyan változik a közös beteggondozás hatására.

Megjegyzem továbbá, hogy ennek az pontnak szándékosan nem az előnyök és hátrányok címet adtam. Ha a közös beteggondozás révén a hármas célrendszert szem előtt tartjuk, akkor a betegek egészségi állapotában javulás érhető el a minőségi ellátás hatására, miközben az egészségügyi rendszerben költségcsökkenés realizálható. Azaz, ha a hármas célrendszerre alapozunk, akkor nem hátrányokkal csak kihívásokkal szembesülünk, amelyeket véleményen szerint megfelelő egészségpolitikai intézkedésekkel kezelni lehet.

\subsubsection{Együttmúködés az orvosok között}

Disszertációmban a háziorvosok és a szakorvosok közötti közös beteggondozás során kialakuló kapcsolatokat, hálózatokat vizsgálom. Ezzel összhangban a jelen szakaszban bemutatom az empirikus elemzésemhez kapcsolódó, ebben a témakörben megjelent tanulmányokat.

Lublóy - Váradi [2013] irodalom feldolgozása alapján a háziorvosok a szakorvosokat általában a következő jellemzők alapján választják ki:

- a szakorvos szaktudása,

- a háziorvos korábbi tapasztalata a betegek ellátásával és elégedettségével kapcsolatosan,

- személyes ismeretek a szakorvosról,

- kommunikáció minősége a szakorvossal,

- beteg hozzáférése a szakorvoshoz,

- beteg kérése, hogy melyik szakorvoshoz szeretne menni.

Fontos megjegyezni, hogy hazánkban a szakorvos kiválasztása nem feltétlenül a háziorvos döntése. A betegeknek lehetőségük van szakorvost választani, és ezt a háziorvosnak jelezni. A betegek jellemzően az első alkalommal a szakorvos 
kiválasztásánál mások tapasztalataira hagyatkoznak, fontos számukra az emberségesség, a kompetencia, a pontosság, az elérhetőség, a jó ellátás, illetve a szakorvosok bizonyos szocio-demográfia jellemzői (Lublóy - Váradi [2013]).

A betegek választási lehetőségének következtében a háziorvosok és a szakorvosok közötti kialakuló kapcsolat nem feltétlenül a háziorvos választásának az eredménye, hanem a beteg kérésére is kialakulhat. A kapcsolatszorosság eredményeinek az elemzésénél figyelembe kell vennem, hogy azokban a háziorvosi-szakorvosi kapcsolatokban, amelyek esetében csak néhány beteg kerül gondozásra, vélhetően a beteg kérésére alakult ki a kapcsolat az orvosok között.

A közös beteggondozás az orvosok között szakmai együttmüködést tételez fel, amely lehet formális vagy informális. Disszertációmban Keating és szerzőtársai [1998] kutatása alapján a háziorvosok és a szakorvosok kapcsolatát akkor nevezzem informálisnak, amikor az orvosok egymással e-mail üzeneteket váltanak, telefonálnak, vagy éppen személyesen egyeztetnek egy adott orvosi problémáról úgy, hogy közben a háziorvos nem utalja be a betegét a szakorvoshoz. Amikor a háziorvos egy adott szakorvoshoz beutalja a betegét, akkor az orvosok közötti kapcsolat formálissá válik, hiszen az orvosok közötti, a beteg egészségi állapotával összefüggő további kommunikáció ezt követően szabályozott keretek között zajlik (Barnett és szerzőtársai [2011]). Disszertációmban csak a formális kapcsolatokat vizsgálom a rendelkezésre álló receptadatok alapján.

\subsubsection{Kvalitatív módszertant alkalmazó kutatások az együttmúködések vizsgálatára}

A korábbi szakirodalomban a háziorvosok és a szakorvosok közötti kapcsolatok azonosítása legfőképpen kérdőíves adatgyüjtésen alapult. Jelen pontban az a célom, hogy bemutassak néhány sokat hivatkozott publikációt a témakörben.

Marshall [1998] kérdőíveken alapuló kutatásában azt vizsgálta, hogy a háziorvosok hogyan müködnek együtt a kórházi szakemberekkel. 24 strukturált és négy fókusz csoportos interjút készített Dél- Nyugat Angliában. Arra az eredményre jutott, hogy magas szintü kölcsönös tisztelet és jó együttmüködés fedezhető fel az orvosok között. 
Kevés területen van jelentős nézeteltérés; a legtöbb érintett próbálja kezelni vagy elkerülni a konfliktusokat.

Lou és szerzőtársai [2011] a háziorvosok és szakorvosok kapcsolatát a reumatológia területén vizsgálták. A mintájukban 84 háziorvos 52 szakorvossal tart fent szoros kapcsolatot. A kérdőív alapján a háziorvosok a következő tulajdonságokat emelték ki azzal kapcsolatban, hogy mi alapján választanak szakorvost: fontos a megfelelő kommunikáció és az információcsere, rövid legyen a várakozási idő, egyértelmű felelösségi körök/feladatok legyenek, valamint lényeges, hogy a betegek visszajelzései jók legyenek.

Wensing és szerzőtársai [2011] a Parkinson-kórban szenvedő betegek kezelő orvosainak kapcsolati hálóját térképezték fel önkéntes strukturált kérdőívek segítéségével. A kutatók azt találták, hogy a kapcsolatok jellemzően földrajzi távolságok alapján alakulnak ki, valamint azok az orvosok, akik több Parkinsonkórban szenvedő beteget látnak el, erősebb kapcsolatot tudtak kialakítani más szakterületen dolgozó orvosokkal.

Barnett és szerzőtársai [2011] egy interneten kitöltendő kérdőívet készítettek az orvosok közötti kapcsolatok vizsgálatára. 616 orvos töltötte ki a kérdőívet, a kitöltési arány $63 \%$ volt. A kutatásuknak az volt a fö célja, hogy bebizonyítsák, adminisztratív adatok segítségével is vizsgálhatóak az orvosok közötti kapcsolatok. Arra az eredményre jutottak, hogy minél magasabb a közösen gondozott betegek aránya, annál valószínűbb az orvosok közötti személyes kapcsolat. Barnett és szerzőtársai [2011] kutatása tette megalapozottá és validáltá a kvantitatív módszereken alapuló azon kutatásokat, amelyben a szerzők az orvosok között kapcsolatokat közösen gondozott betegek alapján tételeznek fel; jellemzően adminisztratív adatokat felhasználva.

\subsubsection{Kvantitatív módszertant alkalmazó kutatások az együttmüködések vizsgálatára}

A kvantitatív módszertant alkalmazó kutatásokra szisztematikus irodalom feldolgozást készítettem a Scopus adatbázist felhasználva. Erre az adatbázisra azért esett a választásom, mert ez az adatbázis tartalmazza a legnagyobb absztrakt és citációs gyüjteményt a tudományos folyóiratokra vonatkozóan (Elsevier [2016]). Az 
elemzésbe kizárólag olyan tanulmányokat vontam be, amelyek az orvosok közötti közös beteggondozást kvantitatív módszerrel elemzi (beválogatási kritérium). A Scopus adatbázisban a keresést 2015. szeptember 4-én végeztem.

A szisztematikus irodalom feldolgozást a következő lépések mentén végeztem el:

- Első lépésben azokra a publikációkra szükítettem a keresésemet, amelyeknek az absztraktjában, címében illetve a kulcsszavai között szerepel a "patient sharing" (közös beteggondozás) és " physician" (orvos) kifejezés. A tudományágak közül a Health Sciences (Egészségtudományok) és a Social Sciences \& Humanities (Társadalomtudományok és humántudományok) területeket választottam ki. Szakcikkeket kizárólag tudományos folyóiratok és konferencia tanulmányok között kerestem. A keresés során sem földrajzi, sem nyelvi szükítést nem alkalmaztam. Ezen konfiguráció melletti keresés esetén 29 publikációt kaptam eredményül, melynek bibliográfiai adatait, köztük a tudományos írások rövid tartalmi kivonatát, egy Excel adatbázisba importáltam.

- A szisztematikus szakirodalom feldolgozás második lépésben az absztraktok alapján kizártam azokat a publikációkat, amelyek nem kvantitatív módszertannal készültek. Tizenöt kvalitatív módszertannal készült kutatás kizárását követően 14 tanulmányt vetettem tüzetesebb vizsgálat alá.

- A szisztematikus szakirodalom feldolgozás harmadik lépésében, a tanulmányok átolvasása után, hat további tanulmányt zártam ki. Ezen tanulmányok ugyanis nem az orvosok közötti közös beteggondozást elemzik. Két tanulmány ugyanis csupán az orvosok közötti együttmüködési hálózatot tárta fel; egy tanulmány, amely az együttmüködés vizsgálatának módszertanát ismerteti, kétszer kerül publikálásra (reprint); három publikáció pedig online betegadatok kezelések korai elfogadásához kapcsolódó orvosok közötti együttmüködéseket elemez.

- A szisztematikus szakirodalom feldolgozás negyedik lépésében az elemzésbe eddig bevont tanulmányok hivatkozásjegyzékét átnézve két további tanulmányt vontam be az elemzésbe (Pham és szerzőtársai [2009] és Uddin és szerzőtársai [2011]). 
A szisztematikus irodalom feldolgozás eredményeképp megállapítható, hogy a szakirodalomban kvantitatív eszközökkel összesen tíz tanulmány vizsgálja az orvosok közötti együttmüködéseket (Barnett és szerzőtársai [2012], Landon és szerzőtársai [2012], Pham és szerzőtársai [2009], Pollack és szerzőtársai [2013, 2014, 2015], Uddin [2016]) és Uddin és szerzőtársai [2011, 2015]).

A kvantitatív módszertant alkalmazó kutatások a közösen gondozott betegek alapján tételeznek fel együttmüködést az orvosok között. Az orvosok közötti formális kapcsolatok strukturális jegyeiről csak Európán kívüli országokra vonatkozóan készült pár kutatás, azon kívül egy sem. A szakirodalomban tehát nem található az empirikus kutatásomhoz hasonló kutatás Európára, és bár a fenti eredmények transzferálhatósága jelentősen megkérdőjelezhető, de empirikus kutatásomnak az alapján jelentik ezek a kutatások, így bemutatásuk mindenképpen szükséges.

Barnett és szerzőtársai [2012] 61461 orvos között kialakuló kapcsolatot vettek górcső alá. Az orvosok 528 kórház egyikében dolgoztak az Egyesült Államokban. A több mint hatvanezer orvos körülbelül 2,6 millió beteget gondozott közösen. A kutatás értelmében 100 közösen kezelt beteg esetében egy orvos átlagosan 187 orvossal áll kapcsolatban. A fö kutatási kérdés az volt, hogy a közös beteggondozás során kialakuló hálózatok milyen hatással vannak a felmerülő költségekre és az ápolás intenzitására. Barnett és szerzőtársai [2012] arra az eredményre jutottak, hogy minél több orvossal áll kapcsolatban egy orvos (szerteágazó, ám de laza kapcsolatrendszer), annál magasabb az egészségügyi ellátás során felmerülő eszközök igénybevétele és nagyobbak a felmerülő költségek. Ennek az ellenkezője mondható el abban az esetben, ha egy orvos kisebb számú, ámde szorosabb kapcsolatot tart fent a kollégáival. Összességében elmondhatjuk, hogy a szoros együttmüködés az orvosok között a társadalom érdeke, hiszen költségcsökkenést eredményez.

Landon és szerzőtársai [2012] 68288 orvos közötti kapcsolatot vizsgáltak meg, akik 51 különböző kórházi régióba tartoznak az Egyesült Államok területén. A szerzők arra a következtetésre jutottak, hogy a különböző földrajzi régiókban eltérés tapasztalható az orvosok közötti kapcsolatokban. Az orvosok között sokkal szorosabb az együttmüködés, ha azonos kórházban dolgoznak, vagy földrajzilag közel van a 
praxisuk. A homofília ${ }^{5}$ is kirajzolódik az eredményeikben, azaz a kapcsolatok általában a hasonló jellemzőkkel rendelkező orvosok és beteg portfólió tulajdonságok menték alakulnak ki.

Pollack és szerzőtársai [2013] 9596 szívbeteg és 52688 diabéteszes beteg esetében vizsgálták az orvosok közötti kapcsolati hálót az Egyesült Államokban. A betegek öt nagy privát biztosító szolgáltatását vették igénybe. A szerzők az együttmüködéseket úgy vizsgálták, hogy a szoros és a gyenge kapcsolatokat hasonlították össze egymással. Arra az eredményre jutottak, hogy a szoros kapcsolatban kezelt betegek esetében, azaz azokban az esetekben, ahol magas a közösen gondozott betegek aránya, alacsonyabb a felmerülő ellátás költsége és a kórházi ellátás aránya. A kutatásuk eredményét az orvosok közötti jobb kommunikációval magyarázták.

Pollack és szerzőtársai [2014] 8661 rákbeteg esetében hasonló eredményre jutottak, mint a 2013-as kutatásukban, azaz minél több rákbeteget kezelnek közösen az orvosok, annál alacsonyabb az ellátás költsége. Pollack és szerzőtársai [2015] legújabb kutatásukban 1,7 milliós betegadatot tartalmazó adatbázist vizsgálva arra jutottak, hogy a szoros kapcsolatban kezelt páciensek esetében alacsonyabb a kórházba visszakerülés aránya.

Uddin és szerzőtársai [2011] a kezelt betegek ellátási költségét és a minőségét vizsgálták. A szerzők az ellátás minőségét a kórházba visszakerülés arányával mérték. Az ausztráliai adatok alapján szintén arra az eredményre jutottak a kutatók, összhangban a korábban bemutatott kutatásokkal, hogy az orvosok közötti kapcsolatok szorosságának pozitív hatása van az ellátás költségére, alacsonyabb visszakerülési arány mellett, miközben a betegek életkorának nincs szignifikáns hatása.

Uddin és szerzőtársai [2015] 2.229 orvos és 2.352 beteg közötti hálózatban lineáris regresszió segítségével azt vizsgálták, hogy az együttmüködési struktúráknak hatással vannak-e az kórházi ellátás költségére és a kórházba való visszakerülési arányra. A

\footnotetext{
${ }^{5}$ A homofília azt az elvet jelenti, hogy az emberek közötti kapcsolat inkább hasonló személyek között jön létre, mint az eltérőek körében. A hasonlóság sokféle területen megmutatkozik: a legtöbben a hozzájuk hasonló életkorú, vallású, képzettségü, foglalkozású személyekkel alakítanak ki és tartanak fenn kapcsolatot (McPherson és szerzőtársai [2001]).
} 
szerzők arra az eredményre jutottak, hogy minél több orvos tartozik egy adott hálózatba, annál magasabb az ellátás költsége.

Uddin [2016] kibővítette a 2015-ös kutatását több magyarázó változóval, és többváltozós statisztikai eljárás alkalmazását követően megerősítette a korábbi számításai eredményét.

Pham és szerzőtársai [2009] 576875 beteg orvosai közötti kapcsolatokat vizsgálták. A betegeket összesen 2248 háziorvos kezelte. Egy tipikus háziorvos 229 szakorvossal tartja a kapcsolatot, akik 117 különböző praxisban dolgoznak. A kutatók arra az eredményre jutottak, hogy azok a háziorvosok létesítenek sokkal több kapcsolatot, akik egyedül, vagy kétszemélyes praxisban vannak, városban vagy nagyvárosban dolgoznak, akiknél magas a krónikus betegséggel rendelkező páciensek aránya, és akik alacsonyabb bevételt kapnak a biztosítótól.

Az alfejezet összefoglalásaképpen elmondható, hogy a közös beteggondozás nagy múltra tekint vissza, kiterjedt szakirodalom jelent meg a témakörben, és szinte mindenhol megtalálható ez a betegellátási rendszer. Számos előnnyel rendelkezik, ugyanakkor kihívást rejt napjainkban is a hármas cél (a társadalom egészsége, az ellátás költsége, az ellátás minősége) együttes megvalósítása. A közös beteggondozásban létrejövő kapcsolatok elemzésére a disszertációmban a napjainkban egyre nagyobb népszerüségnek örvendő kvantitatív módszertant választom, amelyet az adminisztratív adatokhoz való egyedülálló hozzáférésem teszi lehetővé. $\mathrm{Az}$ adminisztratív adatok alapján Európában elsőként vizsgálom a háziorvosok és szakorvosok azon formális együttmüködését, amely a közös beteggondozás révén alakul ki. 


\section{EMPIRIKUS KUTATÁS}

Jelen fejezetben az empirikus kutatásomat mutatom be részletesen. Az első alfejezetben a saját kutatásom során alkalmazott módszertant, majd ezt követően az eredményeket ismertetem. A fejezetet a megbeszéléssel, azaz az eredményekből levont következtetésekkel és szakpolitikai ajánlásokkal zárom.

\subsection{Módszertan}

Jelen alfejezetben ismertetem a saját kutatásom során alkalmazott módszertant, ezen belül a felhasznált adatbázisokat, az adatbázisok összekapcsolásának módját, valamint a tisztított és egymással összekapcsolt adatbázisban található betegek, háziorvosok és szakorvosok jellemzőit. Ezt követően a háziorvosok és a szakorvosok között a közös beteggondozás során létrejövő együttműködési struktúrát vizsgálom. A kutatás menetét a 4. ábra foglalja össze.

\section{4. ábra - A kutatás felépítése}

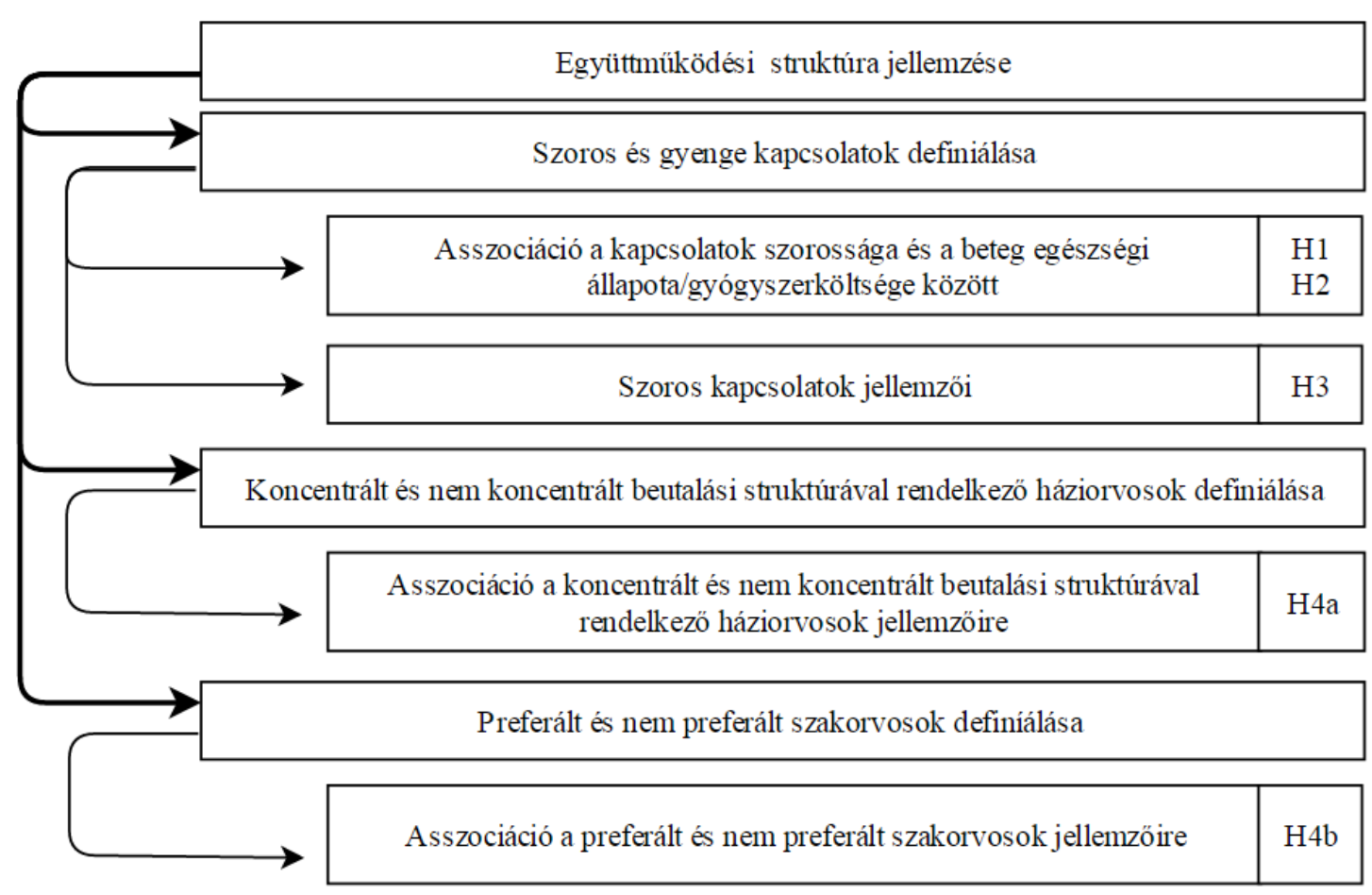

Forrás: saját szerkesztés. 
Az együttmüködési struktúra megismerése után módomban van definiálni azt, hogy mely kapcsolatokat nevezek szorosnak és gyengének. Ezt követően a koncentrált és nem koncentrált beutalási struktúrával rendelkező háziorvosok definícióját, illetve a preferált és nem preferált szakorvosok definícióját határozom meg. Az alfejezetet a három különböző definícióhoz tartozó hipotézisek, az eredményváltozók, valamint a modellspecifikáció bemutatásával zárom.

\subsubsection{A felhasznált adatbázisok}

Elemzésem során két fő és három egyéb adatbázist használtam fel. A két fő adatbázis közül egyik a receptadatokat tartalmazza, a másik az orvosok jellemzőit.

\subsubsection{Felírt gyógyszerek adatbázisa}

A vizsgálat alapadatait, azaz a receptadatokat a DoktorInfo Kft. biztosította kutatási célra, amely adatbázisba közel 900 háziorvos szolgáltat adatot. A DoktorInfo Kft. 2003-ban alakult egészségügyi adatgyüjtő és információ szolgáltató vállalat. Adatbányászati, piackutatási és szekunder elemzési szolgáltatásokkal, az adatbázisokhoz társuló elektronikus informatikai rendszerek fejlesztésével foglalkozik. Az adatgyüjtés orvosi szoftvergyártó cégekkel együttmüködve valósul meg (Doktorinfo Kft. [2015]). Az adatbázisba a hazánkban praktizáló háziorvosok közel ötöde önkéntesen küldi be a vényköteles recepten szereplő adatokat, amelyért cserébe díjazásban részesül.

A rendelkezésemre álló adatbázisban négy fő adatcsoport szerepel:

- A gyógyszert felíró háziorvos nevével és pecsétszámával rendelkezem. A háziorvosok mintája reprezentatív nem, régió, településtípus és belgyógyász szakvizsga léte tekintetében. A minta reprezentativitásának igazolásához a

Doktorinfo Kft. adatait több szempontból is megvizsgáltam, a reprezentativitási vizsgálat eredményei az adatok ismertetése után találhatóak.

- Az adatbázis tartalmaz betegadatokat is, a beteg jellemzői közül a beteg korát és nemét, illetve egy betegazonosítót. Az Országos Egészségügyi Pénztár számára a háziorvosok kötelező jelleggel jelentik a beteg identitására (beteg TAJ száma, neve és lakcíme) is kiterjedő receptadatokat, ezen adatok azonban 
szigorúan bizalmasak; azokra a Doktorinfo Kft. Adatvédelmi Biztos Irodája által auditált adatgyüjtési tevékenysége nem terjed ki, így én csak egy olyan betegazonosítóval rendelkezem, amely segítségével nem tudom a betegeket egyáltalán azonosítani, de képes vagyok betegszintủ adatok aggregálására.

- 2009. január 1-től a háziorvosoknak kötelező a közös beteggondozásban részt vevő betegek esetében a recepten azon szakorvos nevét vagy pecsétszámát feltüntetni, aki az adott terápia háziorvosi utánírását a beteg részére elrendelte. Ily módon, közvetetten ugyan, de ismerem a beteg szakorvosát is.

- A beküldött receptadatok tartalmazzák a felírt készítmény jellemzöit:

○ A felírt készítmény nevét.

○ A felírt készítmény adagolását.

○ A felírt készítményre vonatkozó gyógyszertámogatás mértékét.

- ATC kódot (Anatomical Therapeutic Chemical (ATC) Classification System), amely egy anatómiai, gyógyászati és kémiai osztályozási rendszer, amit gyógyszervegyületek osztályozására fejlesztett ki a WHO Collaborating Centre for Drug Statistics Methodology részlege 1976-ban (WHOCC [2016]).

○ TTT-kód (Társadalombiztosítási Támogatási Termék kód), amely a konkrét gyógyszer azonosítását szolgáló kilenc számjegyből álló kód, ezt az azonosítót az OEP határozza meg a gyógyszerek társadalombiztosítási támogatásba történő befogadásakor (53/2007 (XII. 7.)).

○ BNO-kód a Betegségek Nemzetközi Osztályozására szolgáló kódrendszer, a nemzetközi szakirodalomban a kódrendszert angolul ICD-nek rövidítik (The International Statistical Classification of Diseases and Related Health Problems) (ESKI (2016]).

Fontos kiemelni, hogy a Doktorinfo Kft. adatbázisába a háziorvos vagy minden betegéröl beküldi az adatokat, vagy nem veszt részt az adatküldésben. Ennek következtében az adatot szolgáltató háziorvosnak minden betegéről rendelkezem adattal, valamint egy betegre minden háziorvos által felírt receptet tartalmaz az adatbázis, nemcsak azokat a recepteket, amelyeket a háziorvos szakorvosi javaslatra írt fel. 
Az adatbázis alapján a vizsgált minta meghatározásához fel tudom használni nemcsak az ATC-kódokat, hanem BNO kódokat is, így biztosítani tudtam, hogy az általam elemezni kívánt betegpopuláción végezzem a kutatást.

Az adatbázis alkalmazása során két tényező ad aggodalomra okot: a reprezentativitás, illetve a díjazás ellenében való önkéntes beküldés.

Elsőként a reprezentativitás ellenőrzését végeztem el a kutatásom során. A háziorvosok önkéntes adatszolgáltatása megkérdőjelezhetővé teszi a minta reprezentativitását. A minta reprezentativitásának igazolásához a Doktorinfo Kft. adatait több szempontból is megvizsgáltam. Az adatbázisba közel 900 háziorvos szolgáltat adatot. Mivel a KSH [2011a] adatai alapján 2010 végén 4926 aktívpraktizáló felnőtt háziorvos volt Magyarországon, a mintabeli 900 háziorvos a teljes sokaságra vonatkozóan 18,27\%-os lefedettséget jelent. Ez a lefedettség elég nagy ahhoz, hogy abból országos reprezentatív minta legyen készíthető. További vizsgálataimat az alábbiak jelentették:

\section{5. ábra - Háziorvosok nemek szerint összetételének összehasonlítása a Doktorinfo Kft. és a KSH Egészségügyi adatbázisa alapján}
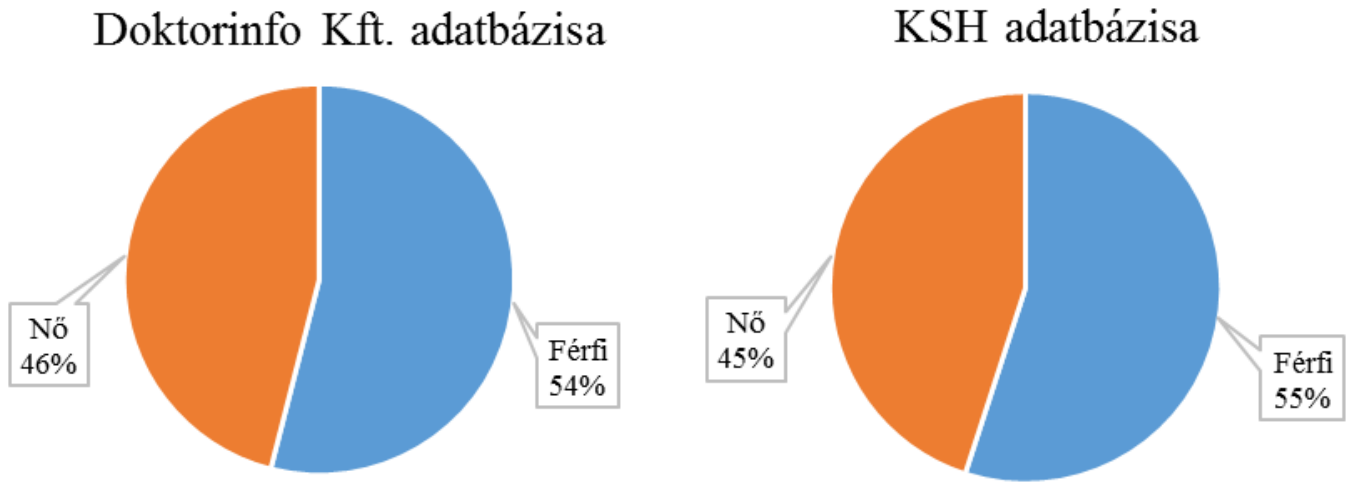

Forrás: KSH (adatigénylés alapján), Doktorinfo adatbázisa alapján saját számítás.

Az 5. ábrán nem összetételben a KSH által nyilvántartott egészségügyi adatokhoz hasonlítottam a Doktorinfo Kft-nek adatot szolgáltató háziorvosok nemének adatait. 
Regionális összetételben a KSH által nyilvántartott egészségügyi adatokhoz hasonlítottam a Doktorinfo Kft-nek adatot szolgáltató háziorvosok rendelőjének régióbeli elhelyezkedési adatait (6. ábra).

\section{6. ábra - Háziorvosok régiók szerinti összetételének összehasonlítása a Doktorinfo Kft. és a KSH Egészségügyi adatbázisa alapján}

Doktorinfo Kft. adatbázisa

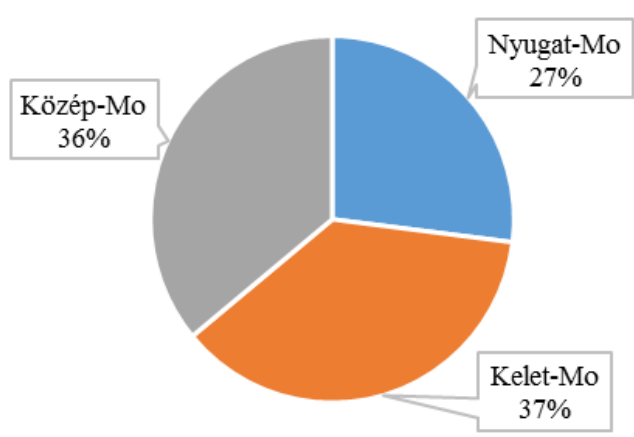

KSH adatbázisa

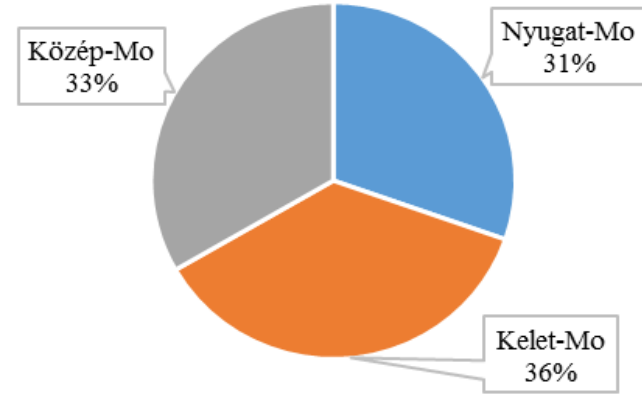

Forrás: KSH [2011a], Doktorinfo adatbázisa alapján saját számítás.

A 7. ábrán település típusonkénti összetételben a KSH által nyilvántartott egészségügyi adatokhoz hasonlítottam a Doktorinfo Kft-nek adatot szolgáltató háziorvosok rendelőjének településtípus szerinti elhelyezkedési adatait.

\section{7. ábra - Háziorvosok település típus szerinti összetételének összehasonlítása a Doktorinfo Kft. és a KSH Egészségügyi adatbázisa alapján}

Doktorinfo Kft. adatbázisa

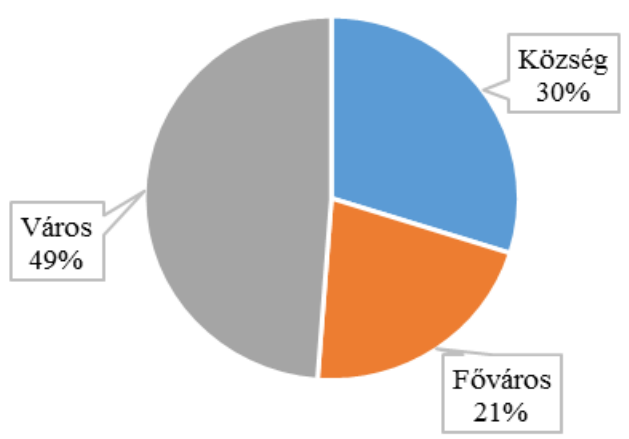

KSH adatbázisa

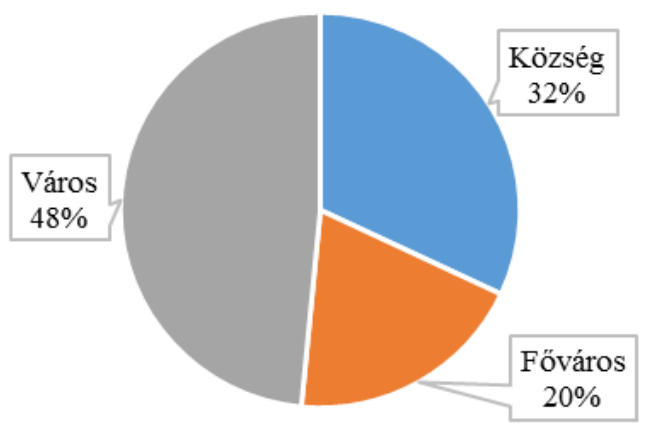

Forrás: KSH [2011a], Doktorinfo adatbázisa alapján saját számítás.

Végezetül, a háziorvosi minta reprezentativitásának fontos és mérhető vetülete a belgyógyász szakvizsgával rendelkező háziorvosok aránya. A Doktorinfo Kft. 
adatbázisát csak a számukra rendelkezésre álló, a KSH-tól igényelt adatbázissal lehet összevetni, amely alapján az a következtetés vonható le, hogy ebben a tekintetben is reprezentatív a minta.

Összefoglalva, azon tényezők tekintetében, amelyek mérhetők és lehetővé teszik a Doktorinfo Kft. háziorvosi adatbázisának reprezentativitási vizsgálatát, e tényezők mindegyikére megoszlási szempontból reprezentatívnak bizonyult az adatbázis.

Másodszor felmerül a mintavétel hibájának az a kérdése, hogy vajon az önkéntesen beküldött adatok alapján a teljes sokaságra vonhatunk-e le következtetéseket. Véleményem szerint az adatszolgáltatásban való részvétel hátterében többféle motiváció lehet a plusz díjazáson felül. Logikus döntés lehet a háziorvosoknak az adatszolgáltatásban való részvétel, elsősorban azért, mert az adatszolgáltatás nem okoz semmilyen plusz terhet az orvosoknak, az adatokat automatikusan továbbítja a receptíró szoftver. Másodsorban a háziorvosoknak az OEP felé is jelentenie kell az adatokat, akik szintén elemzéseket végeznek az adatbázison. Herber és szerzőtársai [2009] számos okot feltártak, hogy az orvosok miért nem vesznek részt kutatásokban. Véleményem szerint az általuk felsorolt okok közül jelen esetben a legrelevánsabb tényező: attól félnek, hogy az adatbázist megvásárlók fel tudják tárni receptfeltárási szokásaikat.

A következtetések általánosításánál fontos észben tartunk Hunyadi és Vita [2002, 255. old] gondolatát: „A statisztikai hiba, aminek egy része a módszertan sajátosságaiból adódik, a statisztika szükségszerü velejárója.”

\subsubsection{Orvosok adatait tartalmazó adatbázis}

A másik fő adatforrásom az Egészségügyi Nyilvántartási és Képzési Központ adatbázisa (továbbiakban ENKK, amely korábban Egészségügyi Engedélyezési és Közigazgatási Hivatal néven volt ismert). Az ENKK jogszabályokban feladat- és hatáskörébe utalt egyik tevékenysége az egészségügyi dolgozók müködési nyilvántartásának vezetésével kapcsolatos feladatok ellátása. Az Alap- és Müködési keresőben elérhetőek az ENKK által nyilvántartott egészségügyi szakképesítést szerzett személyek jogszabály által meghatározott, bárki számára hozzáférhető adatai, amelyek alapján a háziorvosok és a szakorvosok szociodemográfiai és munkahelyi 
jellemzőit töltöttem le. (ENKK [2015]). Az elérhető adatok közül a következő adatokat használtam fel: név, pecsétszám, életkor, egyetemi végzettség helye, ideje, szakvizsgák száma, szakmai tapasztalat években, jelenlegi munkahely címe, jelenlegi pozícióban eltöltött évek száma, pozíció/beosztás, jelenlegi munkahely nagysága.

\subsubsection{Egyéb felhasznált adatbázisok}

A kutatásom során három egyéb adatbázis adataira támaszkodtam még.

1) Országos Egészségbiztosítási Pénztár Ártámogatási Főosztálya folyamatosan közzéteszi a Publikus Gyógyszertörzset (PUPHA), a támogatott gyógyszerek adatait tartalmazó publikus gyógyszeradatbázist (OEP [2014]). A 2011-es gyógyszerárakat tartalmazó adatbázis alapján a támogatott gyógyszerek teljes árat határoztam meg. Fontos kiemelni, hogy az adatbázis tartalmazza a készítmények különböző mértékü támogatott árát is, de én a kutatásomban a teljes árral számoltam. Ennek az az oka, hogy a támogatási formák közül hazánkban a közgyógyellátás területi illetékességü, így az elemzést torzítaná a közgyógyellátásra felírt receptek ára. Ennek elkeserülése érdekében empirikus kutatásomban a betegek által kifizetett ár helyett a teljes árral kalkulálok.

2) A Központi Statisztikai Hivatal (továbbiakban KSH) 2011-es Helységnévkönyv Adattár adatbázisa tartalmazza minden helység lakosságszámát, így ez alapján kategorizálni tudtam minden egyes várost a város népessége alapján (KSH [2011b]).

3) A Google Maps adatai alapján ki tudtam kalkulálni az orvosok rendelői közötti, közúton megtehető távolságokat. Az adatbázis használatára egy Excelben használható Visual Basic kódot írtam, így könnyebben le tudtam tölteni az orvosok közötti távolságmátrixhoz szükséges adatokat.

\subsubsection{Adatbázis építés, vizsgált minta meghatározása}

A jelen szakaszban egyrészt bemutatom az adatbázis építés lépéseit, azt hogy az előző részben ismertetett öt adatbázist hogyan kapcsoltam össze. Másrészt kitérek arra, hogy hogyan határoztam meg a kutatási kérdésben vizsgált mintát. 


\subsubsection{Adatbázis építés}

Az adatbázis építés előtt felmerül a kérdés, hogy az adatbázis milyen mértékben tartalmaz hibás adatokat, amelyek leginkább az adatrögzítés során keletkezhettek, például nem megfelelő a szakorvos pecsétszáma, neve. A kutatásom keretében erre a feladatra nem kellett kitérnem, mert a receptadatbázis tisztítását a Doktorinfo $\mathrm{Kft}$ elvégezte. Az adatbázis tisztítás az adatszolgáltatónál a következőket jelenti:

- hiányzik az orvos pecsétszáma, azonban a neve ismert

- az orvosok nevének formátuma nem egyező, azaz egyes esetekben szerepel a név elött pl.: a Dr. titulus, más esetekben pedig nem

- egy pecsétszámhoz több különböző orvos-név is található

- adott név mellett különböznek a pecsétszámok

- csak pecsétszám található, név nem.

A Doktorinfo Kft. szövegbányászati módszerekkel végezte el az adattisztítást. A hiányzó adatokat az ENKK adatbázis alkalmazásával pótolta. Az orvosok neveit azonos formátumra alakította. Az egy pecsétszámhoz tartozó több orvos közül, illetve egy adott név mellett szereplő különböző pecsétszámok esetében szövegtávolságfüggvényekkel segítségével javították ki ezen adatrögzítési hibákat.

A 8. ábra szemlélteti az öt adatbázis kapcsolatrendszerét. A Doktorinfo Kft. receptadatbázisában szereplő TTT-kódokat az OEP adatbázisban található TTTkódokkal összekapcsolva meg tudtam határozni a háziorvos által felírt receptek betegenkénti gyógyszerköltségét. Egy adott beteg gyógyszerköltségének meghatározásakor minden a háziorvos által az adott beteg számára írt receptet figyelembe vettem, nemcsak a háziorvos által szakorvosi javaslatra felírt recepteket néztem.

A tisztított receptadatbázisban található pecsétszámok alapján össze tudtam kapcsolni a Doktorinfo Kft. adatbázist az ENKK orvos jellemzőket tartalmazó adatbázisával. A receptadatbázist nemcsak a háziorvosok pecsétszámával kapcsoltam össze, hanem a szakorvosok pecsétszámával is, hiszen minden adatbázisban található orvos jellemzőinek ismerete szükséges a kutatáshoz. 
A címadatbázisban az irányítószámokhoz rendeltem az adott település kategorizált méretét, és a KSH Helységnévkönyv adatbázisa alapján meghatároztam a városméret változót az ENKK adatbázisban található munkahelyek címére. Ennek segítségével kategorizálni tudom, hogy az adott orvos milyen nagyságú településen dolgozik. A Google Maps adatbázis alkalmazásával az orvosok rendelőjének egymás közötti távolságát kalkuláltam ki. Az orvosok címadatbázisa és a Google Maps adatbázisa révén meg tudtam határozni a háziorvosok és szakorvosok rendelöi közötti, közúton megtehető távolságokat, valamint a szakorvosok egymás közötti távolságát.

\section{8. ábra- Az adatbázisok kapcsolatrendeszérenk kivonata}

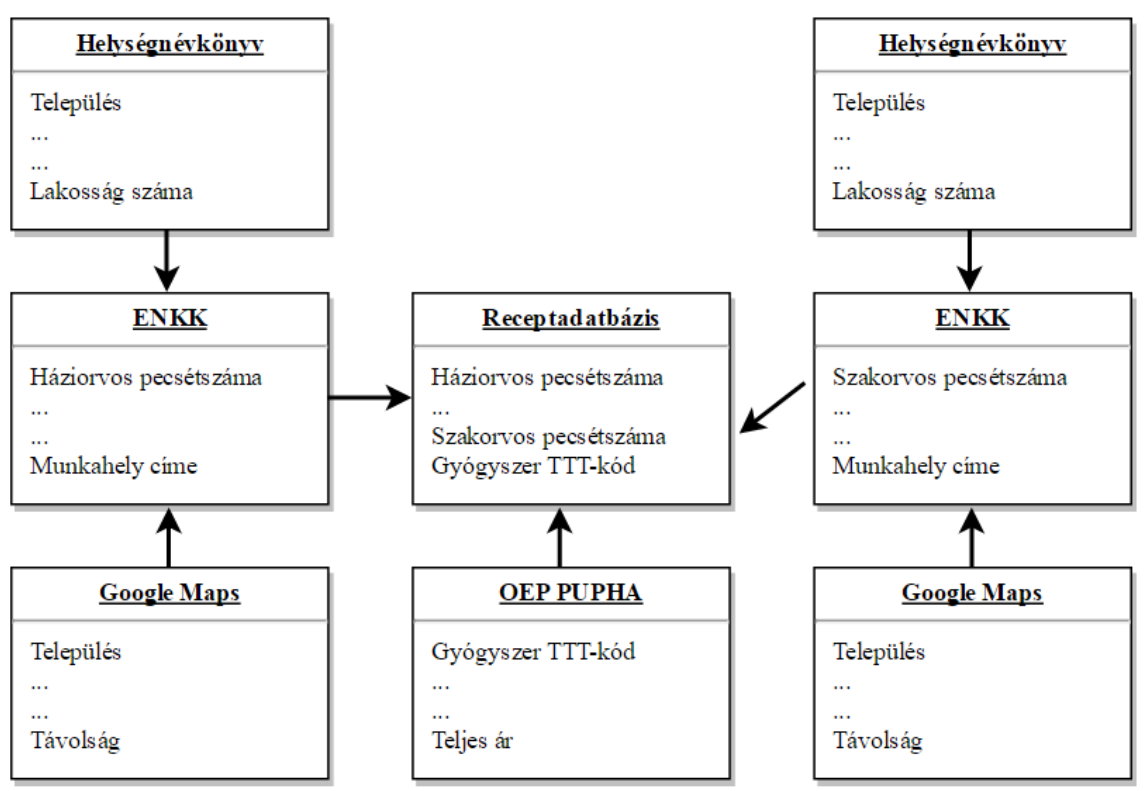

Forrás: saját szerkesztés.

\subsubsection{A betegpopuláció meghatározása}

Az empirikus kutatás során a DoktorInfo Kft. teljes betegpopulációjából csak a 2 . típusú diabétesszel rendelkező pácienseket vettem górcső alá. Ehhez a döntéshez ugyan számos ok vezetett, de a legfőbb motivációm az volt, hogy megtaláljam a háziorvosi-szakorvosi együttmüködés következményeinek vizsgálatához a legideálisabb populációt.

A 2-es típusú diabéteszben szenvedők aránya napjainkban rendkívül magas, és folyamatosan növekszik. Jelenleg 347 millió embernek van cukorbetegsége a világon 
(Danaei és szerzőtársai [2011]), és az előrejelzések alapján 2030-ban a hetedik helyet fogja elfoglalni a halálozási okok listáján (WHO [2011]). Magyarországon a cukorbetegek kezelésére a közös beteggondozás keretében kerül sor. A beteg számára megfelelő gyógyszert a szakorvosnak kell megtalálnia, amit az ő ajánlása alapján a háziorvosnak után kell írnia egy meghatározott ideig, általában egy évig.

A háziorvosok és a szakorvosok közötti együttmüködések vizsgálatához a 2. típusú diabéteszben szenvedő páciensek azért jelentenek jó kiindulási alapot, mert egyrészt ezen krónikus betegek esetében a legnagyobb a háziorvosok és szakorvosok által közösen ellátott betegek populációja, másrészt itt a legmagasabb a szakorvosi javaslatra felírt háziorvosi receptek száma (Doktorinfo [2009]). Harmadrészt a cukorbetegség kezelésére szolgáló készítmények támogatott formában történő felírására a szakorvosok csak egy jól körülhatárolt csoportja jogosult, hiszen azokat csak a belgyógyászok és az endokrinológusok írhatják fel (44/2004. (IV. 28.) ESzCsM rendelet). Ezeknek a sajátosságoknak köszönhetően a kapcsolat-szorosság vizsgálatához a lehető legnagyobb forgalmat lebonyolító részhalmazt tudtam elemezni.

Mivel a receptadatbázisban egy adott háziorvos minden betege megtalálható, így szükítenem kellett a mintát a 2. típusú cukorbetegekre; ezt a receptadatbázisban található adatok alapján tettem meg, azaz az ATC és a BNO kódok alapján választottam ki a vizsgált betegpopulációt. Ezt követően kiválasztottam azokat a betegeket, akik minimum 40 évesek, hogy 1. típusú cukorbetegeket ne tartalmazzon a minta, valamint azokat a háziorvosoknak a betegeit is kizártam, akiknek nincs minimum 10 cukorbetegük.

\subsubsection{Adatbázis jellemzői}

A jelen szakaszban részletesen bemutatom a tisztított összekapcsolt adatbázisban szerepelő 2. típusú diabéteszes betegek, valamint az őket kezelő háziorvosok és szakorvosok jellemzőit. Ezen leíró statisztikai elemzés birtokában lehetőség nyílik az adatbázis megismerésére. 


\subsubsection{Betegek jellemzői}

A 2. táblázatban látható az empirikus kutatás során elemzett 31070 2. típusú cukorbeteg leíró statisztikája. A mintában a páciensek 53,04\%-a férfi, az átlagéletkoruk 65,81 év, a legfiatalabb beteg 40 éves. A páciensek 69,91\%-ánál lépett fel szövődmény. Tipikus diabéteszes szövődmények a szív- és érrendszeri betegségek, az idegkárosodás, a vese-, szem-, és látáskárosodás, bőr és szájbetegségek, illetve a csontritkulás (Hídvégi [2013]). Kutatásom során akkor definiáltam egy beteget szövődménnyel rendelkezőnek, ha a vizsgált két évben (2010-2011), akár egyszer is, a recepten szereplö BNO-kód alapján az orvos a beteget szövődményes cukorbetegségben szenvedőként diagnosztizálta.

A betegpopuláció negyedik fontos, a 2. táblázatban feltüntetett jellemzője a betegek terápiájának jellege, amely lehet inzulin, illetve nem inzulin. A terápia jellege az ATC kód alapján került meghatározásra. A 2.1.1.1. pontban leírtak alapján ismert minden gyógyszer esetére egy öt szintü ATC kód. A harmadik szintű ATC kód tartalmazza a fő anatómia csoportot (első szint, egy betü), a fő terápiás csoportot (második szint, két számjegy), és a terápiás alcsoportot (harmadik szint, egy betü), de nem tartalmazza a kémiai/terápiás/farmakológiai alcsoportot (negyedik szint, egy betü), illetve a gyógyszer kémiai hatóanyagát (ötödik szint, két betü) (WHO [2003]). A harmadik szintű A10 ATC kód azt jelenti, hogy a háziorvos a páciensnek cukorbetegség kezelésére alkalmas készítményt (antidiabetikum) írt fel. Az A10A az inzulin terápia, az A10B pedig a nem inzulin terápia kódja. Ezen kódok alapján a betegek 56,65\%-a inzulin kezelésben részesül.

A betegpopuláció ötödik fontos, 2. táblázatban szereplő jellemzője a betegeknek felírt receptek mennyiségével kapcsolatos. A 2010-2011-es időszakban összesen 4085107 darab receptet írtak fel a háziorvosok a vizsgálatba bevont diabéteszes betegeknek, amelyböl 841916 felírás a cukorbetegség kezelésére történt. Egy beteg átlagosan 131,5 receptet kapott a vizsgált két év során, amelyből átlagosan 27,1 darab a cukorbetegségének kezelésére szolgált. 
2. táblázat - A beteg portfólió leíró statisztikája

\begin{tabular}{|c|c|c|c|c|c|}
\hline \multicolumn{2}{|l|}{ Megnevezés } & Átlag & Min & Max & Szórás \\
\hline \multicolumn{6}{|l|}{ Nem (fö / \%) } \\
\hline férfi & $16479(53,04 \%)$ & - & - & - & - \\
\hline nő & $14591(46,96 \%)$ & - & - & - & - \\
\hline Átlagéletkor (év) & & 65,81 & 40 & 103 & 10,92 \\
\hline \multicolumn{6}{|c|}{ Cukorbetegség típusa (BNO kód alapján, (fö / \%)) } \\
\hline szövődmény nélküli & $21721(69,91 \%)$ & & & & \\
\hline szövödményes & $9349(30,09 \%)$ & & & & \\
\hline \multicolumn{6}{|c|}{ Terápia jellege (harmadik szintü ATC kód alapján, (fö / \%)) } \\
\hline inzulin & $17600(56,65 \%)$ & & & & \\
\hline nem inzulin & $13470(43,35 \%)$ & & & & \\
\hline \multicolumn{6}{|c|}{ Egy betegre jutó receptek száma (darab) } \\
\hline összes recept & & 131,5 & 2,0 & 634,0 & 97,0 \\
\hline $\begin{array}{l}\text { ebböl: cukorbetegség kezelésére } \\
\text { felírt recept }\end{array}$ & & 27,1 & 1,0 & 139,0 & 18,0 \\
\hline \multicolumn{6}{|c|}{ Egy betegre jutó konzultációk száma (darab) } \\
\hline $\begin{array}{l}\text { háziorvossal, összes felírást } \\
\text { figyelembe véve }\end{array}$ & & 22,5 & 1,0 & 150,0 & 13,6 \\
\hline $\begin{array}{l}\text { szakorvossal, új szakorvosi } \\
\text { javaslatot generáló felírásokat } \\
\text { figyelembe véve }\end{array}$ & & 2,3 & 0,0 & 29,0 & 2,2 \\
\hline
\end{tabular}

Forrás: saját szerkesztés a Doktorinfo adatbázisa alapján.

A betegpopuláció hatodik jellemzője az egy betegre jutó konzultációk száma. Egy beteggel egy háziorvos átlagosan 22,5-szer konzultált a vizsgált két év alatt, amely összesen 697552 receptfelírást generáló konzultációt jelentett. Az új szakorvosi javaslatot generáló konzultációk száma átlagosan 2,3 darab. A beteg ennél a valóságban valószínűleg többször konzultált a szakorvossal, például egy új terápiáival, illetve gyógyszer beállításokkal kapcsolatban. 


\subsubsection{Háziorvosok jellemzői}

Doktorinfo Kft. általam felhasznált adatbázisában a cukorbetegekre történő szürés, majd az adattisztítás után 794 háziorvos található.

3. táblázat - Leíró statisztika a 794 háziorvos vonatkozásában

\begin{tabular}{|c|c|c|c|c|c|}
\hline VÁLTOZÓ MEGNEVEZÉSE & Adatbázis & Átlag & Min & Max & Szórás \\
\hline Háziorvos neme (\%) & ENKK & & & & \\
\hline férfi & & $432(54,41 \%)$ & - & - & - \\
\hline nő & & $362(45,59 \%)$ & - & - & - \\
\hline Háziorvos életkora (év) & ENKK & 54,5 & 29,0 & 86,0 & 10,4 \\
\hline $30-39$ & & $76(9,57 \%)$ & & & \\
\hline $40-49$ & & $170(21,41 \%)$ & & & \\
\hline $50-59$ & & $276(34,76 \%)$ & & & \\
\hline $60-69$ & & $212(26,7 \%)$ & & & \\
\hline $70-79$ & & $60(7,56 \%)$ & & & \\
\hline Egyetemi végzettség helye (\%) & ENKK & & & & \\
\hline Budapest & & $224(28,21 \%)$ & - & - & - \\
\hline Debrecen & & $227(28,59 \%)$ & - & - & - \\
\hline Szeged & & $118(14,86 \%)$ & - & - & - \\
\hline Pécs & & $150(18,89 \%)$ & - & - & - \\
\hline külföld & & $75(9,45 \%)$ & - & - & - \\
\hline Szakmai tapasztalat (év) & ENKK & 30,5 & 5,0 & 62,0 & 10,4 \\
\hline $\begin{array}{l}\text { Jelenlegi munkahelyen eltöltött } \\
\text { idő (év) }\end{array}$ & ENKK & 17,6 & 0,0 & 51,0 & 10,5 \\
\hline $\begin{array}{l}\text { Jelenlegi munkahely } \\
\text { városmérete }\end{array}$ & \begin{tabular}{|l} 
KSH, \\
ENKK
\end{tabular} & & & & \\
\hline Főváros & & $121(15,24 \%)$ & & & \\
\hline Nagyváros $(<100 \mathrm{e})$ & & $131(16,5 \%)$ & & & \\
\hline Közepes település $(40-100 \mathrm{e})$ & & $53(6,68 \%)$ & & & \\
\hline Kisváros (>40e) & & $489(61,59 \%)$ & & & \\
\hline Szakvizsgák száma (darab) & ENKK & 1,9 & 0,0 & 6,0 & 0,8 \\
\hline Betegek száma (fö) & Doktorinfo & 39,1 & 10 & 153 & 20,2 \\
\hline
\end{tabular}

Forrás: saját szerkesztés az ENKK, KSH és a Doktorinfo adatbázisai alapján. 


\subsubsection{Szakorvosok jellemzői}

A háziorvosok közül ugyanis kivettem a mintából azon háziorvosokat, akik nem rendelkeztek legalább 10 diabéteszes beteggel. Ezzel az adattisztítási lépéssel célom azon háziorvosok kizárása volt, akik csak néhány hónapig szolgáltattak a Doktorinfo Kft. adatbázisába adatot.

A 3. táblázat alapján megállapítható, hogy a mintámba bevont háziorvosok $54,4 \%$-a férfi, az átlagéletkorunk 54,5 év, a legfiatalabb orvos 29 éves. Az orvosok életkorának megoszlása is jól mutatja azt, amire a szakemberek folyamatosan felhívják a figyelmet, nevezetesen, hogy a háziorvosok közel egyharmada nyugdíj korhatár körül vagy felett van. A legtöbb háziorvos Debrecenben szerezte meg az orvosi diplomáját. A mintában található háziorvosok átlagosan 30,5 éve kapták meg a diplomájukat. Jelenlegi munkahelyükön átlagosan 17,6 éve dolgoznak, de van olyan háziorvos is, aki már 51 éve az adott praxisban tevékenykedik. A háziorvosok 15,24\%-a a fövárosban, 16,5\%a nagyvárosban (több mint 100e fő a népesség, de nem a főváros), 6,68\%-a közepes településen (40-100e közötti népességü településen) és 61,59\%-a kisvárosban (kevesebb mint 40e fö a népesség) praktizál. A háziorvosok átlagosan 1,9 szakvizsgával rendelkeznek, jellemzően sok háziorvosnak van egyéb szakvizsgája, például üzemorvos, belgyógyász, kardiológus. Hat orvosnak nincs szakvizsgája, amelynek oka, hogy régen szerezték meg az általános orvosi diplomájukat, és akkor még nem volt szükség külön háziorvosi szakvizsgára. A háziorvosok átlagosan 39,1 cukorbeteget kezelnek.

A mintába bevont 318 szakorvos leíró statisztikáját és jellemzőit a 4. táblázat tartalmazza.

A mintába bevont szakorvosok 47,35\%-a férfi, átlagosan 52 évesek, a szakorvosok harmada a Semmelweis Orvostudományi Egyetemen diplomázott, és átlagosan 26 éve végeztek az orvosi egyetemen. Jelenlegi munkahelyükön 14,6 éve dolgoznak, de van olyan szakorvos is, aki már 50 éve az adott praxisban tevékenykedik.

A szakorvosok 21,81\%-a a fóvárosban, 28,66\%-a nagyvárosban (több mint 100e fő a népesség, de nem a főváros), 14,64\%-a közepes településen (40-100e közötti népességü településen) és 34,89\%-a kisvárosban (kevesebb mint 40e fő a népesség) dolgozik. A mintába bevont szakorvosok átlagosan 1,8 szakvizsgával rendelkeznek. 


\section{4. táblázat - Leíró statisztika a 318 szakorvos vonatkozásában}

\begin{tabular}{|c|c|c|c|c|c|}
\hline VÁLTOZÓ MEGNEVEZÉSE & Adatbázis & Átlag & Min & Max & Szórás \\
\hline Szakorvos neme (\%) & ENKK & & & & \\
\hline férfi & & $152(47,35 \%)$ & - & - & - \\
\hline nő & & $169(52,65 \%)$ & - & - & - \\
\hline Szakorvos életkora (év) & ENKK & 52,0 & 32,0 & 78,0 & 9,9 \\
\hline $30-39$ & & $33(10,28 \%)$ & & & \\
\hline $40-49$ & & $109(33,96 \%)$ & & & \\
\hline $50-59$ & & $99(30,84 \%)$ & & & \\
\hline $60-69$ & & $67(20,87 \%)$ & & & \\
\hline $70-79$ & & $13(4,05 \%)$ & & & \\
\hline Egyetemi végzettség helye (\%) & ENKK & & & & \\
\hline Budapest & & $110(34,27 \%)$ & - & - & - \\
\hline Debrecen & & $74(23,05 \%)$ & - & - & - \\
\hline Szeged & & $51(15,89 \%)$ & - & - & - \\
\hline Pécs & & $64(19,94 \%)$ & - & - & - \\
\hline külföld & & $22(6,85 \%)$ & - & - & - \\
\hline Szakmai tapasztalat (év) & ENKK & 25,98 & 6,00 & 52,00 & 9,94 \\
\hline $\begin{array}{l}\text { Jelenlegi munkahelyen eltöltött } \\
\text { idő (év) }\end{array}$ & ENKK & 14,56 & 0,00 & 50,00 & 11,56 \\
\hline $\begin{array}{l}\text { Jelenlegi munkahely } \\
\text { városmérete }\end{array}$ & \begin{tabular}{|l} 
ENKK, \\
KSH \\
\end{tabular} & & & & \\
\hline Főváros & & $70(21,81 \%)$ & & & \\
\hline Nagyváros $(<100 \mathrm{e})$ & & $92(28,66 \%)$ & & & \\
\hline Közepes település (40-100e) & & $47(14,64 \%)$ & & & \\
\hline Kisváros $(>40 \mathrm{e})$ & & $112(34,89 \%)$ & & & \\
\hline Szakvizsgák száma (darab) & ENKK & 1,78 & 1,00 & 4,00 & 0,77 \\
\hline Szakorvos beosztása (\%) & ENKK & & & & \\
\hline $\begin{array}{l}\text { felsővezető beosztás } \\
\text { (osztályvezető/ helyettes, } \\
\text { járóbeteg szakellátást vezetője) }\end{array}$ & & $73(22,74 \%)$ & - & - & - \\
\hline vezető beosztás (főorvos) & & $107(33,33 \%)$ & - & - & - \\
\hline $\begin{array}{l}\text { nem vezető beosztás } \\
\text { (tanársegédi vagy adjunktusi } \\
\text { fokozattal rendelkező szakorvos, } \\
\text { szakorvos) }\end{array}$ & & $141(43,93 \%)$ & - & - & - \\
\hline Betegek száma (fö) & Doktorinfo & 123,5 & 14 & 784 & 114,7 \\
\hline
\end{tabular}

Forrás: saját szerkesztés a Doktorinfo, a KSH és az ENKK adatbázisai alapján.

A szakorvosok 22,74\%-a vezető beosztású és 33,3\%-uk föorvos. Egy mintabeli szakorvos átlagosan 123,5 beteget gondozott a vizsgált két év során. 


\subsubsection{Háziorvosok és szakorvosok együttmüködési struktúrájának jellemzése}

A jelen szakaszban a háziorvosok és a szakorvosok együttmüködési struktúráját mutatom be. Az együttmüködési struktúra jellemzése azért fontos, mert ez segít a háziorvosok és a szakorvosok között kialakuló kapcsolatok feltérképezésében. Szakszerủ hipotézisek felállitásához szintén elengedhetetlen, hogy ismerjük ezeket a kapcsolatokat. A közösen gondozott betegek számának, az egy háziorvosra jutó szakorvosok számának ismerete mind segíthet a szoros kapcsolatban álló orvosok definiálásához, és az együttmüködések révén létrejövő kapcsolatok elemzéséhez. A háziorvosok és a szakorvosok együttmüködési struktúrájának jellemzését a Doktorinfo receptadatbázisa alapján végeztem el.

Empirikus kutatásomban egy adott háziorvos és egy adott szakorvos akkor áll kapcsolatban egymással, ha a vizsgált 2 év alatt közösen gondoztak legalább egy cukorbeteget (2010. január - 2011. december). A jelenlegi magyar egészségügyi szabályozás értemében a recepten a háziorvosnak fel kell tüntetnie, hogy melyik szakorvos javaslatára írta fel a készítményt (lásd részletesen 2.1.1.1. pont), így a háziorvosi-szakorvosi hálózat feltérképezhetővé válik.

A 9. ábrán a 318 szakorvos és a 794 háziorvos közötti 6323 kapcsolatot FruchtermanReingold algoritmus alkalmazásával jelenítettem meg. Az ábra alapján megállapítható, hogy egy nagyon sok központtal rendelkező struktúra alakult ki. Ennek az az oka, hogy egy háziorvos több szakorvoshoz küldi a betegeit, és ezen szakorvosokhoz sok más háziorvos is küld beteget. A középpontokban tehát a szakorvosok találhatóak. A 9. ábra jelentősen torzított, hiszen ha nemcsak a diabetológus szakorvosok lennének rajta, hanem minden szakorvos, akkor a háziorvosok lennének a középpontok, hiszen ők küldik a betegeiket a szakorvosokhoz. A struktúra jelentősen széttagolt. 


\section{9. ábra - A háziorvosok és a szakorvosok hálózati struktúrája}

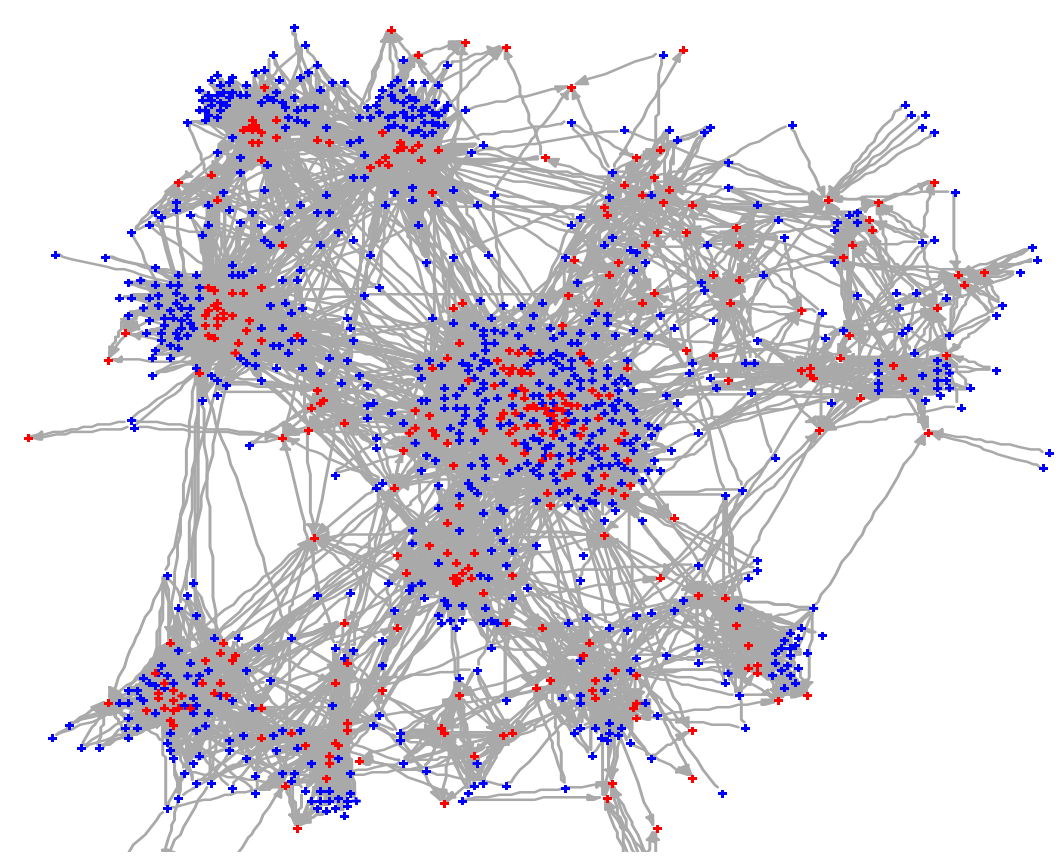

Forrás: saját szerkesztés a Doktorinfo adatbázisa alapján.

A 10. ábrán az látható, hogy egy háziorvos hány szakorvossal müködik együtt. 14 háziorvos csak egy szakorvossal áll kapcsolatban, de található az adatbázisban olyan háziorvos is, aki 28 szakorvoshoz utalta be a betegeit. A háziorvosok több mint $50 \%$ a öt és kilenc közötti szakorvossal tartja a kapcsolatot. Egy háziorvos átlagosan nyolc szakorvossal áll kapcsolatban.

\section{0. ábra - Egy háziorvosra jutó szakorvosok száma}

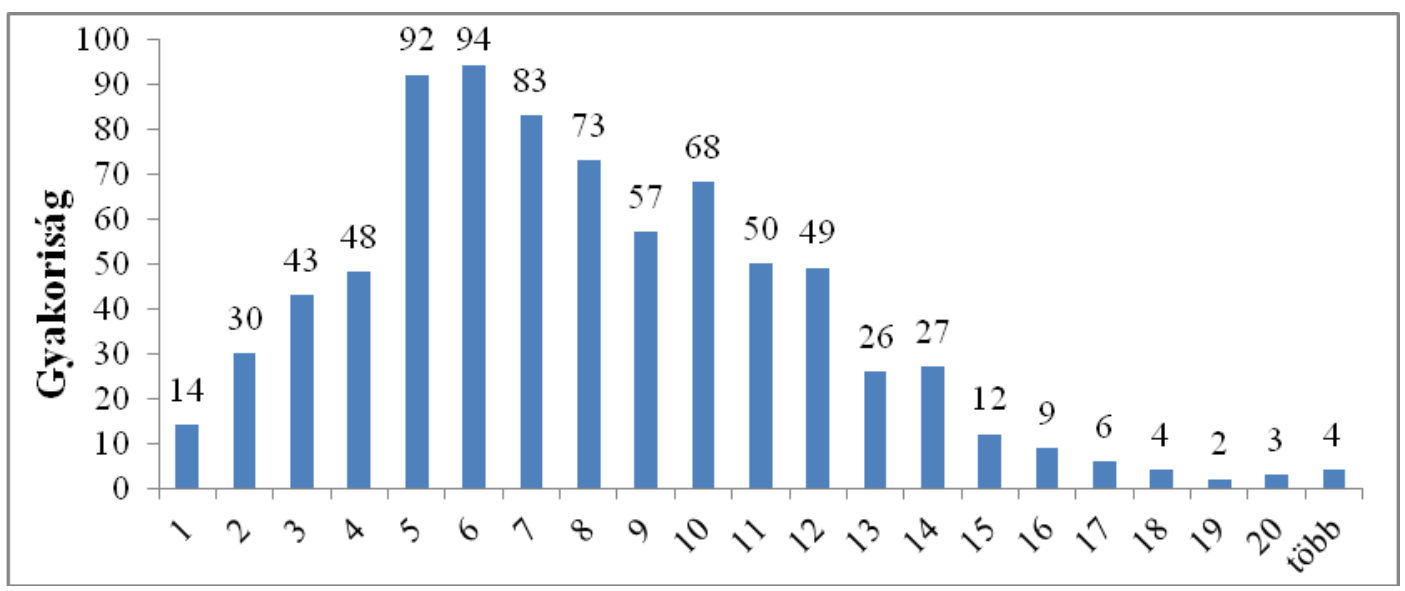

Forrás: saját szerkesztés a Doktorinfo adatbázisa alapján. 
A 11. ábrán a közösen gondozott betegek által generált háziorvosi-szakorvosi kapcsolatok betegszám szerinti eloszlása látható. A kapcsolatok közel 40\%-a esetén a háziorvosok és a szakorvosok csak egy beteget gondoznak közösen. Az orvosok ezen kapcsolatok esetében csupán a betegek 6,6\%-át látják el. Egy adott háziorvosiszakorvosi kapcsolatban a legtöbb közösen gondozott beteg 111 fö. A kapcsolatok 70 \%-a egy és öt közötti közösen gondozott betegen alapul, amelyek esetében a betegek 23,2\%-a kerül ellátásra. A kapcsolatok 9\%-ában több mint 15 beteget gondoznak közösen az orvosok, és ezekben a kapcsolatokban a betegek 43,2\%-a kerül ellátásra.

\section{1. ábra - A háziorvosi-szakorvosi kapcsolatok közösen gondozott betegek száma szerinti eloszlása}

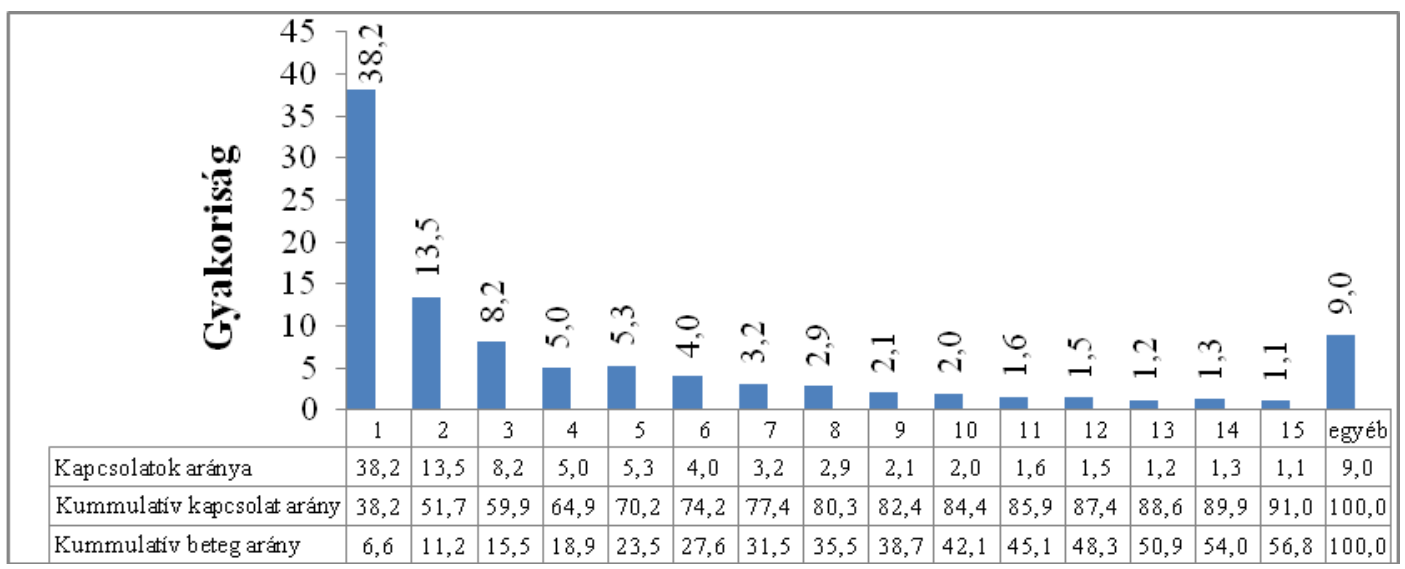

Forrás: saját szerkesztés a Doktorinfo adatbázisa alapján.

Összefoglalva megállapítható, hogy nagyon eltérő mintázatot mutatnak a háziorvosiszakorvosi kapcsolatok mind az egy-egy háziorvosból kiinduló szakorvosi kapcsolatok, mind az egyes kapcsolatokban közösen gondozott betegek számának nagymértékü eltérése miatt.

\subsubsection{Együttműködések definiálása}

A jelen szakaszban definiálom a szoros és gyenge kapcsolatokat. A szoros és gyenge kapcsolatok eredményei fényében szükséges az orvos jellemzők mélyebb szintü feltárása. Ennek révén a háziorvosok és a szakorvosok jellemzőit érdemes megvizsgálni a különböző kapcsolatok esetében. A szoros és gyenge kapcsolatok definíciója alapján egy háziorvos vagy szakorvos kerülhet egyszerre a szoros és a gyenge kapcsolatban lévő orvosok közé, így fontos két új definíció bevezetése, 
amelyek segítségével egyértelmüen elkülöníthetőek egymástól az orvos jellemzők. Ezen okok miatt szükséges a koncentrált és a nem koncentrált beutalási struktúrával rendelkező háziorvosokat, valamint a preferált és nem preferált szakorvosokat is definiálni.

Láthattuk, hogy az egy háziorvosra jutó szakorvosok száma nagymértékben ingadozik (10. ábra). Ezen felül jelentős mértékben eltér az egyes kapcsolatokban közösen gondozott betegek száma is (11. ábra). Mindezek miatt a különböző típusú együttmüködések azonosítása nem egyszerü feladat. Azon kapcsolatok, amelyekben magasabb a közösen gondozott betegek száma, vélhetően szorosabbak, hiszen ezen orvosok között gyakoribb szakmai interakció tételezhető fel. A háziorvosi-szakorvosi kapcsolatok szorosságának eloszlása ferde, valamint a kapcsolat vélhetően nem lineáris, ahogy azt Pollack és szerzőtársai [2013] is feltételezték. Ezeknek az ismereteknek a fényében az egyes együttmüködésekben gondozott eltérő betegszám miatt az orvosok közötti kapcsolatok szorosságának megállapításához inkább egy relatív mintsem egy abszolút betegszámra vonatkozó küszöbszám szükséges. A küszöbszám két meghatározó tényezője a közösen gondozott betegek száma, illetve a betegek szakorvosok közötti megoszlása.

\subsubsection{A szoros és gyenge kapcsolatok definíciója}

Kutatásom során elöször a betegeket hozzárendeltem az egyes háziorvosi-szakorvosi kapcsolatokhoz. Ha egy beteg több szakorvost is felkeresett a megfigyelési periódus alatt, akkor a beteget egyszerre több háziorvosi-szakorvosi kapcsolathoz rendeltem hozzá a következő módon. Meghatároztam, hogy egy adott szakorvos a beteg szakorvosi javaslatra kapott összes készítménye közül arányaiban mennyit javasolt, majd ezt az arányszámot súlyként az adott szakorvos betegéhez rendeltem. Ezt követően a háziorvosi-szakorvosi 6323 kapcsolatot betegarány mentén csökkenő sorba rendeztem (5. táblázat). Egy kapcsolatot szoros kapcsolatnak definiáltam, ha az adott együttműködés a felső ötödben található.

Vizsgálatom során ez akkor állt fenn, ha egy háziorvos a betegeinek több mint 19,2\%át egy adott szakorvoshoz irányította. Ezzel szemben egy adott háziorvosi-szakorvosi kapcsolat definíciószerüen akkor gyenge, ha az az alsó ötödben található. Ez esetben egy adott háziorvos a betegeinek kevesebb mint 2,3\%-át kezeli közösen egy adott 
szakorvossal. A két szélsőséges eset közötti kapcsolatokat közepes szorosságúként definiáltam. Fontos megjegyezni, hogy egy háziorvos egyszerre több mint egy szakorvossal lehet szoros kapcsolatban, kutatásom során ehhez mindössze annyi kell, hogy legyen legalább két olyan szakorvos, akikhez a betegei több mint 19,2\%-át küldi.

\section{5. táblázat - Szoros és gyenge kapcsolat meghatározásának szemléltetése}

\begin{tabular}{|c|c|c|c|c|c|}
\hline \multirow{6}{*}{ 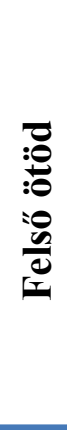 } & Sorszám & Háziorvos & Szakorvos & Betegarány & \multirow{6}{*}{$=\underset{\text { kapcsolat }}{\text { Szoros }}$} \\
\hline & 1 & GP1 & SP1 & $100 \%$ & \\
\hline & 2 & GP2 & SP1 & $100 \%$ & \\
\hline & $\ldots$. & & & & \\
\hline & 1263 & GP50 & SP20 & $19,2 \%$ & \\
\hline & 1264 & GP51 & SP21 & $19,2 \%$ & \\
\hline \multirow{8}{*}{ 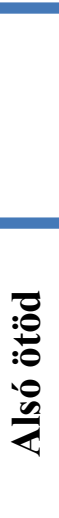 } & 1265 & & & & \multirow{8}{*}{$\begin{array}{c}\text { Gyenge } \\
\text { kapcsolat }\end{array}$} \\
\hline & $\ldots$ & & & & \\
\hline & 5058 & & & & \\
\hline & 5059 & GP444 & SP140 & $2,3 \%$ & \\
\hline & 5060 & GP444 & SP77 & $2,3 \%$ & \\
\hline & $\ldots$ & & & & \\
\hline & 6322 & GP750 & SP250 & $0,6 \%$ & \\
\hline & 6323 & GP555 & SP56 & $0,6 \%$ & \\
\hline
\end{tabular}

A 12. ábra a kapcsolat-szorosságok eltérő eseteit szemlélteti. A 1-es számú háziorvos (GP1) cukorbetegei döntő többségét, 83\%-át (30 beteget) egy adott szakorvoshoz irányítja. Ez a kapcsolat egy erős háziorvosi-szakorvosi kapcsolat. Az 1-es számú háziorvos többi kapcsolata közepes, hiszen több mint 2,3\%-át küldi egy adott szakorvoshoz, de kevesebb mint 19,2\%-t. A 2-es számú háziorvos (GP2) három szakorvossal tart fent szoros kapcsolatot. Ezen együttmüködések azért szorosak, mert a háziorvos a cukorbetegei legalább 19,2\%-át ezen szakorvosokhoz irányítja: az orvosok közösen 18, 8, 8, beteget kezelnek, amely a háziorvos cukorbetegeinek 49, 22 és 22\%-át teszi ki. A 2-es számú háziorvos a másik három orvoskollégával létesített kapcsolata közepes. Mivel a 3-as számú háziorvos (GP3) egyik szakorvoshoz sem irányítja betegei legalább 19,2\%-át, így annak egyik szakorvossal való kapcsolata sem mondható erősnek, de több szakorvossal is közepes vagy gyenge kapcsolatban van. 


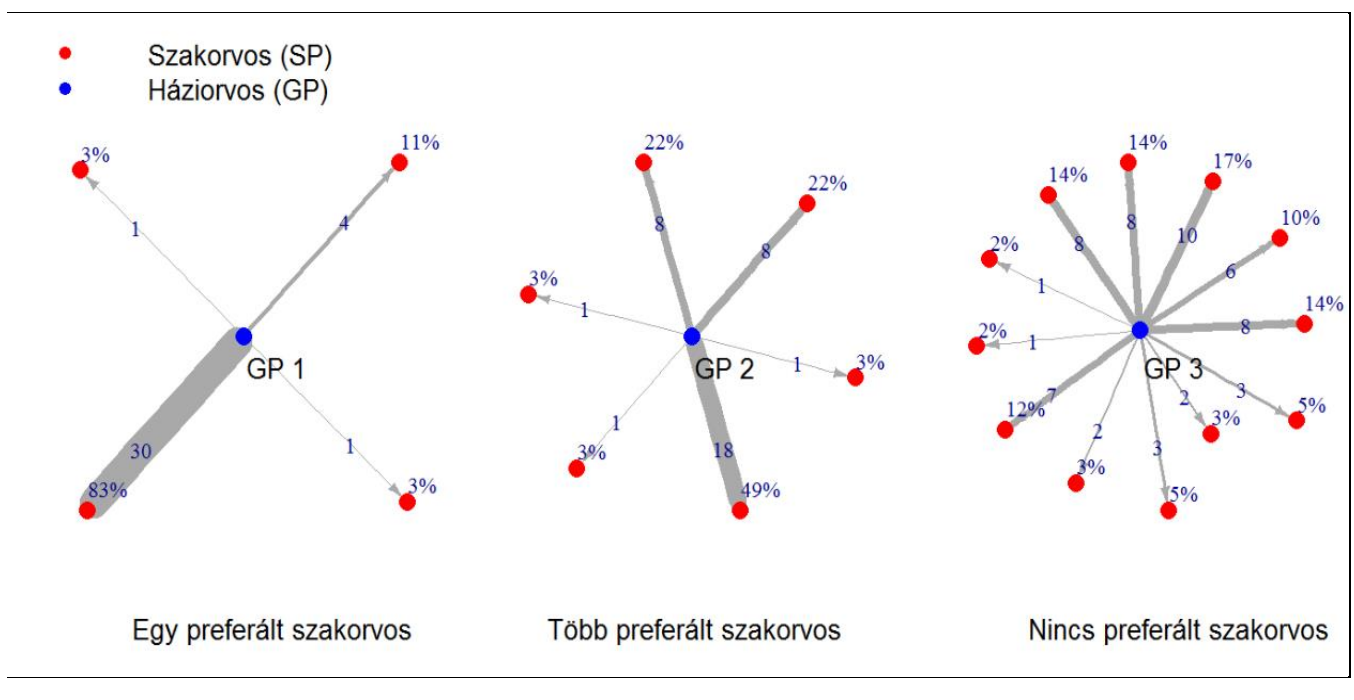

Forrás: saját szerkesztés Doktorinfo adatbázisa alapján.

Érzékenység vizsgálat keretében az erős és gyenge kapcsolatok két további definícióját is megnéztem; ekkor erős és gyenge kapcsolatként a kapcsolatok felső illetve alsó tizedét, valamint a felső és az alsó harmadát definiáltam.

Az eredményváltozók meghatározásánál is figyelemmel kell majd lenni arra, hogy egy beteg több háziorvosi-szakorvosi kapcsolatban is szerepelhet, ennek megfelelöen ezekben az esetekben súlyozott átlagot veszek figyelembe.

\subsubsection{Koncentrált és nem koncentrált beutalási struktúrával rendelkező háziorvosok definíciója}

A szoros és gyenge kapcsolatok definiálása után a kutatásom során egy mélyebb elemzéséhez fontos, hogy a koncentrált és nem koncentrált beutalási struktúrával rendelkező háziorvosokat is definiáljam. Mindezt azzal a céllal teszem, hogy meg tudjam vizsgálni e két csoportba sorolt orvosok jellemzőinek eltérését vagy hasonlóságát. A 794 háziorvos többsége (481 fö) létesít párhuzamosan egyes szakorvosokkal szoros, míg más szakorvosokkal gyenge kapcsolatot. Így az előző pontban megfogalmazott definíció nem alkalmas arra, hogy a koncentrált és nem koncentrált beutalási struktúrával rendelkező háziorvosokat el tudjam egymástól különíteni.

Definícióm szerint egy háziorvos akkor rendelkezik koncentrált beutalási struktúrával, ha bizonyos szakorvosokhoz szorosan kötődik. A koncentráltság 
meghatározásához a legjobban elterjedt koncentráció mérőszámmal, a HerfindahlHirschman index-szel határoztam meg egy adott háziorvos beutalási struktúrájának koncentráltságát (Rhoades [1993]).

$$
\begin{gathered}
H H I=\sum_{i=1}^{n} s_{i}^{2} \text {, ahol } \\
s_{i}=\frac{\text { egy adott háziorvos egy adott szakorvoshoz beutalt betegei }}{\text { egy adott háziorvos összes betege }}
\end{gathered}
$$

Minden háziorvosra kiszámoltam a HHI indexüket, majd a HHI index alapján sorba rendeztem a vizsgált 794 háziorvost, és ennek alapján meghatároztam a koncentrált beutálási struktúrával és a nem koncentrált beutalási struktúrával rendelkező háziorvosokat, hasonlóan az elöző szakaszban bemutatott módszerhez. Azaz relatív viszonyszámot alkalmaztam, és akkor nevezem egy háziorvosnak a beutalási struktúráját koncentráltnak, ha a felső ötödbe került a koncentráltsága alapján. A felső és az alsó ötödbe is 158 háziorvos került. Egy háziorvos akkor rendelkezik koncentrált beutálási struktúrával, ha a HHI indexe 0,1990 felett van, és akkor szétaprózódott beutálási struktúrával, ha a HHI indexe 0,1743 érték alatti.

\subsubsection{Preferált és nem preferált szakorvosok definíciója}

A szoros és gyenge kapcsolatban lévő szakorvosok jellemzőinek összehasonlításához szükséges a preferált és a nem preferált szakorvosok definiálása, hiszen a 2.1.5.1 bemutatott definíció alapján egy szakorvos egyszerre lehet szoros és gyenge kapcsolatban, így egy új definíció szükséges ezen elemzés elvégzéséhez. Fontos kiemelnem, hogy nem a szakorvosok alakítják ki a vizsgált 6323 kapcsolatot, hanem a háziorvosok vagy a háziorvosok betegei, ezért ennek figyelembe vételével kell az adott definíciót kialakítanom.

Definícióm szerint egy szakorvos szoros kapcsolatban van egy háziorvossal, ha ö a háziorvos egyik preferált szakorvosa. Egy szakorvos egy háziorvos preferált orvosa, ha a háziorvos betegeinek legalább 30\%-át oda irányítja, de minimum kilenc föt. Egy háziorvos több szakorvost is preferálhat. A preferáltak azok a szakorvosok, akiket legalább öt háziorvos választ. A mintában található 318 szakorvos közül ezen definícióval 47 szakorvos került a preferált szakorvosok közé. Nem preferált szakorvosnak azt vettem, akiket egyetlenegy háziorvos sem preferál, azaz nem 
irányította hozzá egyik háziorvos sem a betegeinek 30\%-át és minimum kilenc beteget. Ez alapján 140 szakorvos került a nem preferált szakorvosok közé.

A preferált és nem preferált szakorvosok definíciójára érzékenység vizsgálatot is végeztem. Ezen vizsgálat keretében, azt változtattam meg a definícióban, hogy az alap definíció szerint legalább öt háziorvos választja az adott szakorvost (a háziorvos legalább a betegeinek 30\%-át és minimum kilenc főt irányít egy adott szakorvoshoz), az érzékenység vizsgálat során pedig elegendő, ha csak három háziorvos választja az adott szakorvost. Ezek alapján 84 szakorvos lesz preferált az elemzett 318 szakorvos közül. Az érzékenység vizsgálat keretében is a 140 nem preferált szakorvossal hasonlítottam össze a preferált 84 szakorvost.

\subsubsection{Hipotézisek}

Az együttmüködési struktúrák bemutatása, és az együttmüködések definiálása után jelen szakaszban ismeretem a kutatási kérdésem négy hipotézisét.

Elsőként arra a kérdésre keresem a választ, hogy a szoros és gyenge kapcsolatban kezelt betegek egészségi állapota és gyógyszerköltsége között van-e szignifikáns különbség. Az első két hipotézisem vizsgálatára számos korábbi kutatás található (Barnett és szerzőtársai [2012], Landon és szerzőtársai [2012]; Pollack és szerzőtársai [2013, 2014], Pham és szerzőtársai [2009], Uddin és szerzőtársai [2011]), de csak Európán kívüli országokra, valamint e két hipotézis együttes vizsgálatára korábban még nem készült kutatás.

H1: A szoros háziorvosi-szakorvosi kapcsolatban kezelt betegek egészségi állapota jobb.

H2: A szoros háziorvosi-szakorvosi kapcsolatban kezelt betegek gyógyszerkiadása alacsonyabb.

Azért két hipotézisben fogalmaztam meg ezt a két kérdést, mert három esetben is lehet pozitív az eredmény: 
- Az első és a második hipotézist is elfogadom, azaz a szoros kapcsolatban kezelt betegek egészségi állapota jobb alacsonyabb felmerülő gyógyszerköltség mellett.

- Az első hipotézist elutasítom, a másodikat pedig elfogadom, azaz nincs szignifikáns különbség a betegek egészségi állapotában, de alacsonyabb gyógyszerköltség merül fel a szoros kapcsolatban kezelt betegek esetében.

- Illetve az első hipotézist elfogadom és a második hipotézis elutasítom, azaz szignifikánsan jobb a szoros kapcsolatban kezelt betegek egészségi állapota azonos nagyságú felmerülő költség esetében.

Az előbbiekben tárgyalt esetekre tekintettel az eredmények és a megbeszélés alfejezetben az első két hipotézis együttes vizsgálata szükséges.

Az első két hipotézisem legalább egyikének elfogadása esetén érdemes a szoros kapcsolatokat mélyebben feltárni. Landon és szerzőtársai [2012] kutatásuk alapján azt várhatjuk, hogy hazánkban is fent áll a homofília, azaz a háziorvosok a szakorvos kiválasztása során hozzájuk hasonló jellemzőkkel (egyetemi végzettség helye, életkor, nem, munkatapasztalat) rendelkező orvost választanak. Ennek megfelelően állítottam fel a harmadik hipotézisemet. Azt az eredményt várom, hogy hasonló orvosok között alakul ki szoros kapcsolat.

H3: A szoros kapcsolatban álló orvosok hasonlítanak egymásra (homofília).

A negyedik hipotézis keretében azt szeretném feltárni, hogy a koncentrált és a nem koncentrált beutalási struktúrával rendelkező háziorvosok, illetve a preferált és a nem preferált szakorvosok jellemzőikben hasonlítanak-e. Ezek a kérdések véleményem szerint jobban fel tudják tárni a szoros és gyenge kapcsolatok kialakulásának okait.

H4a: A koncentrált beutalási struktúrával rendelkező háziorvosok jellemzőik alapján elkülöníthetőek a nem koncentrált beutalási struktúrával rendelkező háziorvosoktól.

H4b: A preferált szakorvosok jellemzőik alapján elkülöníthetőek a nem preferált szakorvosoktól. 


\subsubsection{Eredményváltozók meghatározása}

Jelen szakaszban meghatározom, hogyan fogom vizsgálni a betegek egészségi állapotát, illetve a betegek gyógyszerköltségét. Ezen változók az empirikus kutatásomban az eredményváltozók.

Az egészség egy többdimenziós fogalom a WHO meghatározása szerint: „Az egészség a teljes testi, lelki és szociális jólét állapota, és nem csupán a betegség vagy fogyatékosság hiánya.” (WHO [1948]). Az egészség fogalmát megragadhatjuk mind az egészségi állapottal, mind az életminőséggel Az egyéni egészségi állapotot lehet mérni különbözö tesztek, vizsgálatok elvégzésével; esetleg a beteg maga értékeli egy kérdőív kitöltésének segítségével. Az egyéni egészségi állapot mérése fókuszálhat tesztek eredményeire (például vérnyomás, vércukor szint), a tünetekre, a társbetegségekre, vagy a mellékhatásokra (amputáció, fájdalom) (Blackwood [2009]).

Disszertációmban a betegek egészségi állapotát a diagnosztizált és kezelt társbetegségek számával közelítem meg. Társbetegségek alatt a vizsgált indexek besorolási algoritmusában található betegségek szerepelnek. Fontos kiemelni, hogy a társbetegség indexek csak egy bizonyos dimenzióját mérik az egészségi állapotnak, de számos empirikus bizonyíték azt mutatja, hogy ezek az indexek jó előrejelzői a halálozásnak. (Charlson és szerzőtársai [1987], Lix és szerzőtársai [2013], Li és szerzőtársai [2008], Sharabiani és szerzőtársai [2012], Quail és szerzőtársai [2011], Quan és szerzőtársai [2011]). Széleskörü használatuk annak köszönhető, hogy a halálozás mellett jól előre tudják jelezni a nemkívánatos eseményeket (például kórházi kezelés, amputáció), és a beteg egészségi állapotát (de Groot és szerzőtársai [2003], Kieszak és szerzőtársai [1999], Lix és szerzőtársai [2013], Quail és szerzőtársai [2011], Rochon és szerzőtársai [1996]).

Számos kutatás megmutatta, hogy a társbetegség indexek alkalmasak a beteg egészségi állapotának mérésére (Bayliss és szerzőtársai [2005], de Jonge és szerzőtársai [2006], Manen és szerzőtársai [2003], Rebollo és szerzőtársai [2000]).

Sharabiani és szerzőtársai [2012] szisztematikus irodalom feldolgozásukban a legnépszerübb társbetegség indexeket vették górcső alá. Arra az eredményre jutottak, hogy a Charlson társbetegség index a legnépszerübb, ezt követi az Elixhauser mérték. 
Azt állapították meg, hogy az Elixhauser mérték tudja leginkább előjelezni a hosszúés a rövidtávú halálozást.

De Groot és szerzőtársai [2003] szisztematikus irodalom feldolgozásukban szintén számos halálozást előrejelző indexet megvizsgáltak, és arra az eredményre jutottak, hogy a Charlson társbetegség index, CIRS (Cumulative Illness Rating Scale), ICED (Index of Coexisting Disease) és a Kaplan Index a halálozás előrejelzésére megfelelő mérőszám.

Huntley és szerzőtársai [2012] szisztematikus irodalom feldolgozásukban arra a következtetésre jutottak, hogy az alapellátásban a Charlson társbetegség index meglehetősen jól közelíti az egészségi állapot bizonyos dimenzióit (halálozás, életminőség, egészségügyi ellátás igénybevétele).

Az elözőekben bemutatott kutatások alapján disszertációmban négy különböző társbetegség indexet alkalmaztam:

- a Charlson-indexet (Charlson és szerzőtársai [1987]),

- a Quan-féle módosított Charlson indexet (Quan és szerzőtársai [2011]),

- az Elixhauser mértéket (Elixhauser és szerzőtársai [1998]), illetve

- egy alternatív indexet.

Ezekre az indexekre azért esett a választásom, mert a nemzetközi szakirodalomban nem egyértelmü, hogy melyik a legjobb index, így inkább több változóval közelítem a beteg egészségi állapotát.

A Charlson társbetegség index a beteg tíz éves túlélési valószínűségét prediktálja 19 különböző betegség jelenlétén illetve hiányán alapuló súlyozott pontozórendszer segítségével (Charlson és szerzőtársai [1987]). A Charlson index esetében mind a 19 betegséghez (AIDS/HIV, malignus lymphoma, leukémia, cerebrovascularis betegség, COPD, kongesztív szívelégtelenség, dementia, hemiplegia vagy paraplegia, szolid tumor, illetve szolid tumor metasztázissal, májbetegség (enyhe fokú illetve mérsékelten súlyos vagy súlyos fokú), myocardialis infarctus, peptikus fekélybetegség, perifériás érbetegség, mérsékelt vagy súlyos fokú krónikus vesebetegség, reumás betegségek) tartozik egy pontszám, ami annál magasabb minél magasabb a halálozási arány. Tekintve, hogy a Charlson index eredeti 1984-es 
kialakítását követően az egyes betegségek halálozási aránya az emberek életminőségében illetve az orvostudomány fejlődésében végbement változások következtében megváltozhatott, a Quan-féle módosított Charlson indexet is meghatároztam, amely esetében a betegségekhez rendelt, halálozási aránnyal összefüggő pontszámok felülvizsgálatra kerültek, de ugyanazok a betegségek esetében kap pontszámot a beteg (Quan és szerzőtársai [2011]).

Az Elixhauser mérték 30 különböző, körültekintően kiválasztott betegség (AIDS/HIV, alkoholizmus, vashiányos anaemia vérveszteségtől, szívritmuszavar, COPD, coagulopathy, kongesztív szívelégtelenség, egyéb anaemia, depresszió, kábítószer függőség, folyadék és elektrolit háztartás betegségei, magas vérnyomás, komplikációval illetve komplikáció nélkül, hypothyroidism, májelégtelenség, lymphoma, metasztázisos szolid tumor, elhízottság, egyéb neurológiai rendellenesség, paralízis, gyomorfekély betegség (vérzés nélkül), perifériás érbetegség, pszichózis, pulmonális szívbetegség, veseelégtelenség, rheumatoid arthritis, szolid tumor (metasztázis nélkül), szívbillentyü-betegség, alultápláltság) előfordulását veszi sorra, majd veszi azok együttes számosságát. Az Elixhauser mértéket kutatásom során Quan és szerzőtársai [2005] cikke alapján, a recepteken szereplő BNO kódok figyelembe vételével határoztam meg.

A társbetegség negyedik mérőszáma egy alternatív index, amely angol megfelelöje Number of Prescription Drugs Dispensed néven terjedt el a vonatkozó szakirodalomban (Lix és szerzőtársai [2016]). Ez az alternatív index a recepteken található ATC kódon alapul. Ezen indexszel célom a BNO kódolásban rejlő esetleges hibák kiküszöbölése volt. Ezen ATC kód alapján meghatározott társbetegség indexnél azon különböző betegségek előfordulását számoltam meg, amelyekre a beteg legalább negyedévente kapott egy vényköteles készítményt (Lix és szerzőtársai [2016]). Az alternatív indexem tehát nem egy súlyozott mutató, hanem egy beteg számára felírt készítmények összesített háromjegyü ATC kódjainak megszámlált értéke.

Sharabiani és szerzőtársai [2012] szerint, az alternatív indexet leszámítva, az általam választott indexek a társbetegségek mérésének legelterjedtebb és legelfogadottabb módját jelentik. Értelemszerűen minél magasabb az index értéke, annál rosszabb a beteg egészségi állapota. Mind a négy társbetegség index esetében a háziorvos által felírt valamennyi receptet figyelembe vettem, a cukorbetegség kezelésére szolgálókat 
éppúgy, mint az összes többit. A társbetegség indexek segítésével lehetőségem nyílik a szoros és a gyenge háziorvosi szakorvosi kapcsolatban lévő betegek egészségi állapotának összehasonlítására.

Cukorbetegek esetében Meyers és szerzőtársai [2014], valamint Lix és szerzőtársai [2013] egyaránt használtak az egészségi állapot mérésére Charlson társbetegség indexet. Lix és szerzőtársai [2013], valamint Quail és szerzőtársai [2011] az Elixhauser mértéket cukorbetegek egészségi állapotának mérésére használták. Ezen a kutatások lehetővé tették számomra, hogy összehasonlítsam a különböző társbetegségek korábbi kutatásokban szereplö mintákon belüli eloszlását az én mintámon belüli eloszlással. Az összehasonlításból azt a következtetést tudtam levonni, hogy rendkívül hasonlítanak a korábbi kutatásokban szereplő gyakoriságok az általam kapott gyakoriságokhoz. Nincsenek kiugró, extrém értékek egyetlen index illetve egyetlen betegségtípus esetében sem (lásd részletesen az 1. és a 2. számú mellékletben).

\section{6. táblázat - Korreláció nagysága a társbetegség indexek között}

\begin{tabular}{|l|c|c|c|c|}
\hline & $\begin{array}{c}\text { Charlson } \\
\text { társbetegség } \\
\text { index }\end{array}$ & $\begin{array}{c}\text { Quan-féle } \\
\text { módosított } \\
\text { Charlson } \\
\text { társbetegség } \\
\text { index }\end{array}$ & $\begin{array}{c}\text { Elixhauser } \\
\text { mérték }\end{array}$ & $\begin{array}{c}\text { Alternatív } \\
\text { társbetegség } \\
\text { index }\end{array}$ \\
\hline $\begin{array}{l}\text { Charlson társbetegség } \\
\text { index }\end{array}$ & 1 & 1 & 1 & \\
\hline $\begin{array}{l}\text { Quan-féle módosított } \\
\text { Charlson társbetegség } \\
\text { index }\end{array}$ & 0,774 & 0,635 & 0,527 & 1 \\
\hline Elixhauser mérték & 0,702 & 0,316 & & \\
\hline $\begin{array}{l}\text { Alternatív } \\
\text { társbetegség index }\end{array}$ & 0,425 & & & \\
\hline
\end{tabular}

Forrás: saját szerkesztés a Doktorinfo Kft adatbázisa alapján.

Az alkalmazott négy társbetegség indexet egymást átfedő skálák alapján lehet meghatározni, melynek fényében elég magas az indexek közötti korreláció mértéke (6. táblázat). Ez az eredmény az intuíciónknak megfelelő, hiszen ugyanazt a fogalmat - a 
beteg egészségi állapotát - közelítem a különböző indexek segítségével. A különbözőképpen meghatározott társbetegség indexek másképpen jelzik elöre a halálozást, más időtávra fókuszálnak (rövid vagy hosszú), valamint a nemkívánatos események más súllyal kerülnek figyelemre vételre (amputáció, hosszabb kórházi kezelés, hosszabb kórházi tartózkodás) (de Groot és szerzőtársai [2003], Lix és szerzőtársai [2013], Li és szerzőtársai [2008], Sharabiani és szerzőtársai [2012]), amelynek fényében az empirikus kutatásom során indokolt egyszerre több index eredményváltozóként történő használata.

Fontos kiemelnem, hogy a társbetegség indexeknél használt társbetegség fogalma eltér a szövődményes cukorbetegség fogalmától. Azt, hogy egy beteg cukorbetegségének típusa szövődményes illetve szövődmény nélküli, azt az adott beteg cukorbetegségének kezelésére felírt receptek BNO kódja alapján határoztam meg (Például E1090 - insulin-dependens cukorbetegség szövődmények nélkül kód esetében a beteg szövődmény nélküli, természetesen csak akkor, ha vizsgált két évben nem szerepel szövődménnyel rendelkező BNO-kód a receptjei között). A társbetegség indexek kiszámításánál pedig az indexek által meghatározott BNO-kódokat vettem az empirikus kutatásom alapul. Ezt úgy tettem meg, hogy Quan és szerzőtársai [2005] publikációjukban bemutatott kódtáblázatot használtam, amelyben megtalálható minden egyes vizsgált betegséghez tartozó BNO-kód.

A gyógyszerköltséget úgy határoztam meg, hogy minden egyes beteg esetében kiszámoltam a háziorvos által 2010-ben és 2011-ben felírt összes gyógyszer teljes árának összegét az OEP adatbázisa alapján (lásd 2.1.1.3. pont). Fontos hangsúlyozni, hogy kutatás során nem a beteg gyógyszerkiadását néztem, tehát nem azt az összeget határoztam meg, amelyet a beteg a patikában fizetett, hanem a készítmények teljes árát figyelembe vettem, ami a beteg által fizetendő összeg mellett magában foglalja az állami támogatás mértékét is. Így a gyógyszerkiadást nem a beteg, hanem az egész társadalom szintjén tudtam nézni.

\subsubsection{Modellspecifikáció}

A H1 és a H2 hipotézis esetében egy adott szakorvosi-háziorvosi kapcsolatban kezelt betegek társbetegség indexének illetve a gyógyszerkiadásának súlyozott átlagát számoltam ki. A súlyozott átlagok kiszámítására azért volt szükség, hogy az eltérő 
mértékű közösen kezelt betegszám a háziorvosok és a szakorvosok között, ne torzítsa el az elemzést. Ezen súlyozott átlagok különbözöségét statisztikai tesztek segítségével vizsgáltam. A betegek egészségi állapotát és a felmerült gyógyszerköltségeket a különböző erősségű kapcsolatok esetén $t$-teszttel hasonlítottam össze. Egy adott eredményváltozót szignifikánsnak akkor neveztem, ha esetében a $p<0,05$. Az erős és gyenge kapcsolatok két másik definíciójára érzékenység vizsgálatot végeztem (az alternatív definíciókat lásd a 2.1.5.1. pontban). A gyógyszerköltségre többváltozós regressziót is illesztettem, amellyel az volt a célom, hogy megállapítsam: a gyógyszerköltségre vajon hogyan hatnak együttesen a változók.

A H3 hipotézis esetében a szoros kapcsolatban lévő háziorvosok és szakorvosok jellemzőit hasonlítottam össze. A H4a hipotézis esetében a koncentrált és a nem koncentrált beutalási struktúrával rendelkező háziorvosokat vettem górcső alá. H4b hipotézis esetében a preferált szakorvosokat hasonlítottam össze a nem preferált szakorvosokkal. Ezen hipotéziseket $\chi^{2}$ próbával teszteltem, azaz azt vizsgáltam, hogy a független diszkrét változók eloszlásának gyakoriságában tapasztalható-e szignifikáns eltérés. Akkor neveztem egy változót szignifikánsnak, ha $p<0,05$.

Az empirikus kutatásom számításaihoz az IBM SPSS Statistics 22 programcsomagját, Microsoft Access, Excel 2013 programját, valamint az R programcsomagot használtam. 


\subsection{Eredmények}

Jelen alfejezetben elsőként azt elemzem, hogy a szoros és gyenge háziorvosiszakorvosi kapcsolat milyen hatással van a beteg egészségi állapotára és a gyógyszerköltségére (H1, H2). Az előző két hipotézis elfogadása vagy elutasítása után fontos része a kutatásomnak azon kapcsolatok azonosítása, amelyek hatással vannak a betegek egészségi állapotára és gyógyszerköltségére.

Felmerül a kérdés, hogy a szoros kapcsolatban együttmüködő háziorvosok és szakorvosok jellemzői különböznek-e a gyenge kapcsolatot létesítő háziorvosokétól és szakorvosokétól (H3).

Az alfejezet végén a H4 hipotézis eredményeit mutatom be. Először azt vizsgálom, hogy tapasztalható-e a koncentrált és a nem koncentrált beutalási struktúrával rendelkező háziorvosok jellemzői között eltérés (H4a). Másrészt azt vizsgálom, hogy van-e a preferált és a nem preferált szakorvosok jellemzői között eltérés (H4b).

\subsubsection{Betegek egészségi állapota és gyógyszerköltsége meghatározása szoros és gyenge kapcsolatok esetében}

A jelen szakaszban a 2.1.5.1. pontban definiált szoros és gyenge kapcsolatban kezelt betegek egészségi állapotát és gyógyszerköltségét veszem górcső alá. A szakaszt a szoros és gyenge kapcsolatban kezelt betegek jellemzőinek összehasonlításával kezdem, majd az egészségi állapot és a gyógyszerköltség vizsgálatával folytatom. A szoros és gyenge kapcsolatok esetében az egészségi állapotra és a gyógyszerköltségre érzékenység és robosztusság vizsgálatot is végeztem. Végezetül a szakaszt a gyógyszerköltségre készített többváltozós regressziós modell eredményeivel zárom.

A 7. táblázatban a szoros illetve a gyenge szakorvosi-háziorvosi kapcsolatban kezelt betegek bizonyos jellemzőit vetettem össze. A szoros és gyenge kapcsolatban kezelt betegek átlagéletkorában, a terápia jellegében és az egy betegre jutó szakorvosi (új szakorvosi javaslatot generáló felírásokat figyelembe véve) konzultációk számában van szignifikáns eltérés a két betegcsoport között. 
A szoros kapcsolatban kezelt betegek átlagosan 1,78 évvel idősebbek, ritkábban keresik fel a szakorvosukat, illetve közülük arányaiban kevesebb beteg részesül inzulin kezelésben.

A két betegpopuláció vonatkozásában nincs szignifikáns különbség a nemek megoszlásában, a cukorbetegségük súlyosságában, az egy betegre jutó receptek számában, akár az összes, akár csak a cukorbetegségük kezelésére felírt készítményeket nézzük, illetve a háziorvossal való kapcsolattartás gyakoriságában.

\section{7. táblázat - A betegek jellemzői a szoros illetve a gyenge háziorvosi-szakorvosi kapcsolatokban}

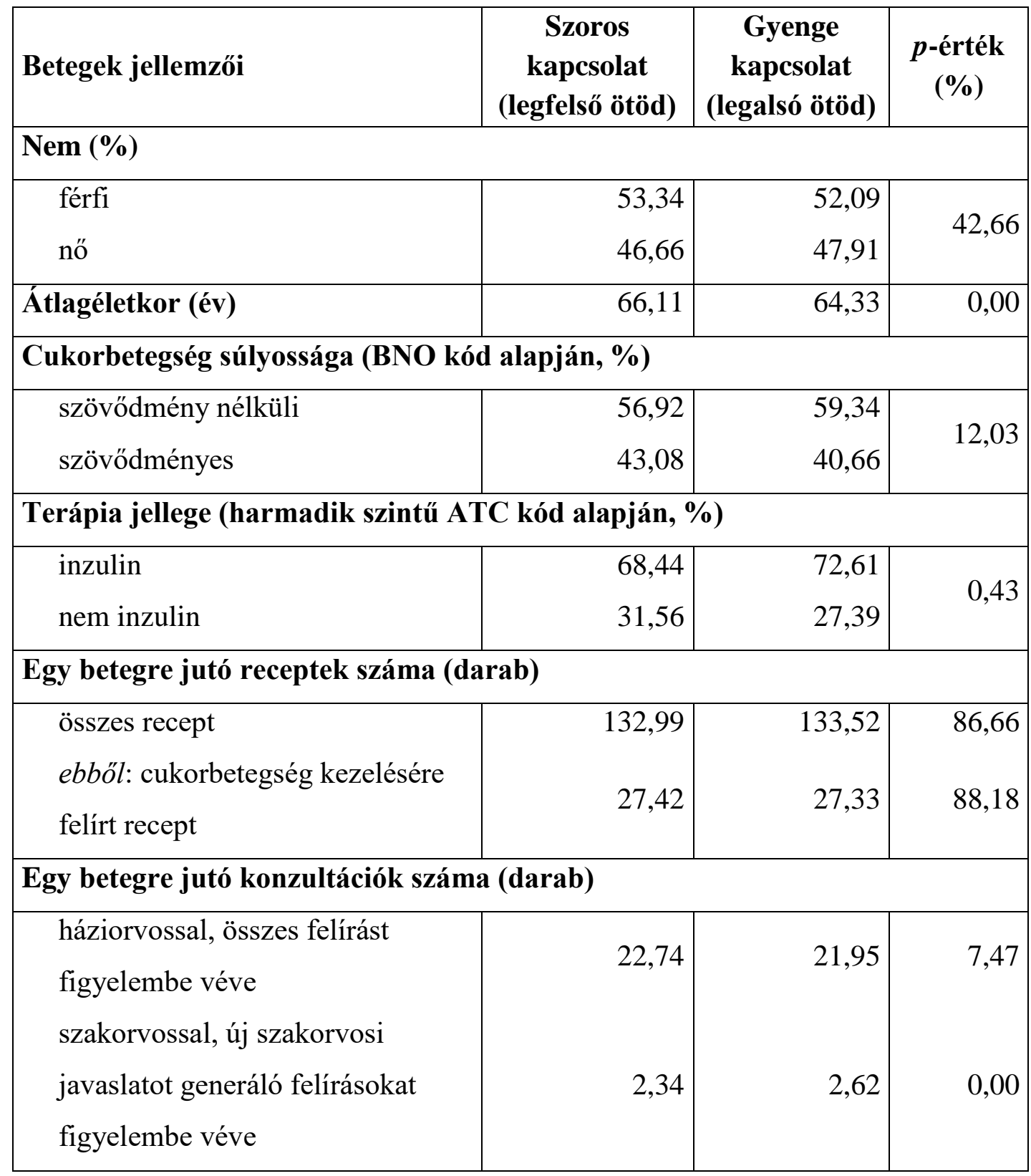

Forrás: saját szerkesztés a Doktorinfo adatbázisa alapján. 
A 8. táblázatban láthatók az első két hipotézisem tesztelésének eredményei. Mind a négy társbetegség index alapján megállapítható, hogy a beteg egészségi állapotára nincs hatással, hogy a beteg szoros vagy gyenge háziorvosi-szakorvosi kapcsolatban kerül kezelésre. A betegek társbetegségeinek száma, akármelyik társbetegség indexet vesszük alapul, a különböző szorosságú szakorvosi-háziorvosi kapcsolatokban közel azonos, tehát az első hipotézisemet el kell utasítanom.

\section{8. táblázat - A szoros és gyenge háziorvosi-szakorvosi kapcsolatok eredményváltozók mentén történő jellemzése}

\begin{tabular}{|c|c|c|c|}
\hline Eredményváltozók & $\begin{array}{c}\text { Szoros } \\
\text { kapcsolat } \\
\text { (legfelső ötöd) }\end{array}$ & $\begin{array}{c}\text { Gyenge } \\
\text { kapcsolat } \\
\text { (legalsó ötöd) }\end{array}$ & $\begin{array}{c}p- \\
\text { érték } \\
(\%)\end{array}$ \\
\hline \multicolumn{4}{|c|}{ Betegek egészségi állapota (kivéve diabétesz) } \\
\hline Charlson társbetegség index & 0,93 & 0,91 & 43,64 \\
\hline $\begin{array}{l}\text { Quan-féle módosított Charlson } \\
\text { társbetegség index }\end{array}$ & 0,60 & 0,60 & 82,66 \\
\hline Elixhauser mérték & 1,98 & 1,95 & 42,33 \\
\hline Alternatív társbetegség index & 8,01 & 7,98 & 83,93 \\
\hline Gyógyszerköltség (ezer HUF) & 612,18 & 721,41 & 0,00 \\
\hline
\end{tabular}

Forrás: saját szerkesztés a Doktorinfo és az OEP adatbázisa alapján.

Az orvosok között kapcsolat szorossága azonban számításaim értelmében összefügg a gyógyszerkiadással: a szoros háziorvosi-szakorvosi kapcsolatban kezelt betegek gyógyszerkiadása 15,14\%-kal alacsonyabb, mint a gyenge kapcsolatban kezelt betegeké. A legfelső ötöd esetében 612,18 ezer Forint a vizsgált két évre vonatkozó átlagos gyógyszerköltség, ezzel szemben a legalsó ötöd esetében 712,41 ezer Forint. A különbség szignifikáns, így második hipotézisemet el kell, hogy fogadjam.

A gyógyszerköltség és a Charlson társbetegség index, a Quan-féle módosított Charlson társbetegség index és az Elixhauser mérték közötti korreláció nagysága kisebb, mint 0,2. A gyógyszerköltség és az Alternatív társbetegség index közötti korreláció mértéke 0,47 .

Az érzékenység vizsgálat során a legfelső és legalsó tized, valamint a legfelső és legalsó harmad a betegek négy társbetegség indexének összehasonlításával a 9. 
táblázatban ismertetett értékek adódtak. A szoros és gyenge kapcsolatban kezelt betegek egészségi állapotában nincs szignifikáns különbség, kivéve az alternatív index esetében a legfelső és a legalsó harmadnál.

\section{9. táblázat - Érzékenység vizsgálat a szoros és gyenge háziorvosi-szakorvosi kapcsolatok egészségi állapot mentén történő jellemzésére}

\begin{tabular}{|l|r|r|r|r|r|r|}
\hline Eredményváltozók & $\begin{array}{c}\text { Szoros } \\
\text { kapcsolat } \\
\text { (legfelső } \\
\text { tized) }\end{array}$ & $\begin{array}{c}\text { Gyenge } \\
\text { kapcsolat } \\
\text { (legalsó } \\
\text { tized) }\end{array}$ & $\begin{array}{c}\boldsymbol{p} \text { - } \\
\text { érték } \\
(\%)\end{array}$ & $\begin{array}{c}\text { Szoros } \\
\text { kapcsolat } \\
\text { (legfelsó } \\
\text { harmad) }\end{array}$ & $\begin{array}{c}\text { Gyenge } \\
\text { kapcsolat } \\
\text { (legalsó } \\
\text { harmad) }\end{array}$ & $\begin{array}{c}\boldsymbol{p} \text { - } \\
\text { érték } \\
(\%)\end{array}$ \\
\hline Betegek egészségi állapota (kivéve diabétesz) \\
\hline $\begin{array}{l}\text { Charlson } \\
\text { társbetegség index }\end{array}$ & 0,93 & 0,97 & 52,21 & 0,94 & 0,93 & 88,77 \\
\hline $\begin{array}{l}\text { Quan-féle módosított } \\
\text { Charlson } \\
\text { társbetegség index }\end{array}$ & 0,60 & 0,63 & 57,34 & 0,61 & 0,62 & 68,26 \\
\hline Elixhauser mérték & 1,98 & 1,95 & 71,61 & 1,99 & 1,94 & 13,31 \\
\hline $\begin{array}{l}\text { Alternatív } \\
\text { társbetegség index }\end{array}$ & 7,99 & 8,30 & 16,35 & 8,03 & 7,79 & 3,25 \\
\hline
\end{tabular}

Forrás: saját szerkesztés a Doktorinfo és az OEP adatbázisa alapján.

A 10. táblázatban az érzékenység és robusztusság vizsgálat található a szoros és gyenge háziorvosi-szakorvosi kapcsolatok esetére. Az érzékenység vizsgálattal annak feltárása volt a célom, hogy ha más definíciók mentén határozom meg a szoros és gyenge kapcsolatokat, akkor is ugyanazok az eredmények adódnak-e. Az adatbázisra készítettem robosztusság vizsgálatot is, amellyel az volt a célom, hogy a túl magas gyógyszerköltséggel rendelkező kiugró, extrém értékeket kizárjam a mintából. A teljes adatbázisra elkészített érzékenység vizsgálat alapján azt a következtetést vonhatjuk le, hogy a szoros kapcsolatban kezelt betegek esetében szignifikánsan alacsonyabb a gyógyszerköltség, mint a gyenge kapcsolatban kezelt betegek esetében. Annál magasabb az átlagos gyógyszerköltség minél nagyobb részhalmazt nézek, azaz a legfelső tized esetében csak 584,65 ezer Forint, a legfelső ötöd esetében 612,18 ezer Forint és a legfelső harmad esetében 616,60 ezer Forint. Ezzel konzekvensen annál alacsonyabb a gyenge kapcsolatok esetében a gyógyszerköltség, minél nagyobb mintát elemzek. A gyógyszerköltségek a vizsgált két évre összesítve kapcsolat szinten átlagolva szerepelnek a táblázatban.

Az öt és nyolc millió Forintnál nagyobb két évre eső gyógyszerköltséggel rendelkező betegeket zártam ki a robosztusság vizsgálat során. A küszöbértékeket a 
gyógyszerköltségre készített boxplot alapján határoztam meg. A magas gyógyszerköltséggel rendelkező betegek elemzésből való kizárása következtében csökkent az átlagos gyógyszerköltség. A szoros kapcsolatok esetében azonban továbbra is szignifikánsan alacsonyabb gyógyszerköltségek merülnek fel, mint gyenge kapcsolatban kezelt betegek esetében.

10. táblázat- Érzékenység és robossztusság vizsgálat a szoros és gyenge háziorvosi-szakorvosi kapcsolatok gyógyszerköltség mentén történő jellemzésére

\begin{tabular}{|c|r|r|r|}
\hline Eredményváltozók & $\begin{array}{c}\text { Minta } \\
\text { adatbázis }\end{array}$ & $\begin{array}{c}\text { 8 millió HUF-nál } \\
\text { magasabb } \\
\text { gyógyszerköltséggel } \\
\text { rendelkezó betegek } \\
\text { nélkül } \\
\text { (két évre kalkulált) }\end{array}$ & $\begin{array}{c}\text { 5 millió HUF-nál } \\
\text { magasabb } \\
\text { gyógyszerköltséggel } \\
\text { rendelkezö betegek } \\
\text { nélkül }\end{array}$ \\
(két évre kalkulált)
\end{tabular}

Forrás: saját szerkesztés a Doktorinfo és az OEP adatbázisa alapján.

A gyógyszerköltségre végzett érzékenység és robosztusság vizsgálat eredményei összhangban vannak a 8. táblázat eredményeivel, azaz a kiugró extrém magas gyógyszerköltséggel rendelkező betegek nem torzítják az elemzést. Így a további elemzésben a teljes mintát fogom alapul venni, nem az extrém értékkel tisztítottat.

Felmerül a kérdés, hogy egy beteg gyógyszerköltségét tényleg magyarázza-e, hogy szoros vagy gyenge kapcsolatban álló orvosok kezelik. Ennek vizsgálatára a 
kétváltozós modellt érdemes a gyógyszerköltségre illesztett többváltozós regresszióval is kiegészíteni.

Első lépésben a magyarázó változók kiválasztását végeztem el. A rendelkezésre álló adatokból kiindulva 15 olyan magyarázó változót választottam ki az elemzéshez, amelyeknek hatása lehet a gyógyszerköltségre: szoros és gyenge kapcsolat a háziorvosok és a szakorvosok között (0- szoros, 1- gyenge kapcsolat), beteg neme, beteg életkora években, a négy társbetegség index (Charlson társbetegség index, Quan-féle módosított Charlson társbetegség index, Elixhauser mérték, Alternatív társbetegség index), egy betegre jutó konzultációk száma (szakorvossal, új szakorvosi javaslatot generáló felírásokat figyelembe véve), egy betegre jutó konzultációk száma (háziorvossal), egy betegre jutó konzultációk száma (háziorvossal cukorbetegség kezelésére felírt készítményeket figyelembe véve), egy betegre jutó receptek száma, egy betegre jutó cukorbetegség kezelésére felírt receptek száma, egy betegre jutó receptek száma kivéve cukorbetegség kezelésére felírt, terápia jellege $(0$-nem inzulin, 1-inzulin), cukorbetegség súlyossága (0- szövődmény mentes, 1- szövődményes).

A kiválasztott 15 magyarázó változóra korrelációs mátrixot készítettem, hogy kizárjam azokat a változókat, amelyek között erős lineáris kapcsolat fedezhető fel. A modell magyarázó változói közül kizártam azokat, amelyek között magas a korreláció értéke (Chiulli [2009]).

A 2.1.7. szakaszban is ismertettem, hogy a társbetegség indexek között magas a korreláció nagysága, ennek hatására csak egy társbetegség indexet szerepeltettem a végső modellben. Az alternatív társbetegség index és az egy betegre jutó receptek száma változó között 0,84 a korreláció értéke, amelynek hatására az alternatív indexet kizártam az elemzésből, hiszen a receptek számának biztosan erős hatása van a gyógyszerköltségre. A BNO kódokra épülő indexek közül a Quan-féle módosított Charlson társbetegség index választottam, mert ennek van a gyógyszerköltségre a legmagasabb magyarázó ereje, amelyet úgy határozta meg, hogy készítettem egy olyan lineáris regressziós modellt, amelyben csak egy adott társbetegség index szerepelt, mint magyarázó változó és a gyógyszerköltség, mint eredményváltozó.

Az egy betegre jutó receptek száma, az egy betegre jutó cukorbetegség kezelésére felírt receptek száma és az egy betegre jutó receptek száma kivéve cukorbetegség kezelésére 
felírt magyarázó változók között nagyon magas a korreláció (0,65-0,98 között), így a modellemben az egy betegre jutó receptek száma változót hagytam benne.

Az egy betegre jutó konzultációk száma (háziorvossal cukorbetegség kezelésére felírt készítményeket figyelembe véve) és az egy betegre jutó konzultációk száma (háziorvossal) erősen korrelál a receptek számával, amelynek hatására ezeket a változókat is kizártam a modellemből. A végső modellemben a kizárások után nyolc magyarázó változó maradt.

A lineáris regresszió alapvetése, hogy a változók között lineárisnak kell lennie a kapcsolatnak, de az adatok grafikus megjelenítéséböl azt a következtetést tudtam levonni, hogy az életkor és a gyógyszerköltség között nem áll fenn ez a kapcsolat, így a modellbe bevontam a beteg életkorának a négyzetét is, amelynek hatására ez a két változó együttesen vélhetően jobban tudja magyarázni az eredményváltozót.

A 11. táblázatban található a többváltozós regresszió a betegek gyógyszerköltségére. A modell magyarázóereje, azaz az $\mathrm{R}^{2}$ értéke 0,396.

11. táblázat - Többváltozós regresszió a betegek gyógyszerköltségére

\begin{tabular}{|c|c|c|}
\hline Magyarázó változók & $\begin{array}{l}\text { Sztend. } \\
\text { koefficiens }\end{array}$ & Szig. \\
\hline & Béta & \\
\hline $\begin{array}{l}\text { Szoros és gyenge kapcsolat a háziorvosok és a szakorvosok } \\
\text { között (0-szoros, 1-gyenge) }\end{array}$ & 0,011 & 0,030 \\
\hline Quan-féle módosított Charlson társbetegség index & $-0,009$ & 0,113 \\
\hline Betegek neme (0-nő, 1-férfi) & $-0,024$ & 0,000 \\
\hline $\begin{array}{l}\text { Cukorbetegség súlyossága }(0-\text { szövődmény mentes, 1- } \\
\text { szövődményes) }\end{array}$ & 0,014 & 0,007 \\
\hline Terápia jellege ( 0 - nem inzulin, 1-inzulin) & 0,202 & 0,000 \\
\hline Egy betegre jutó receptek száma & 0,570 & 0,000 \\
\hline $\begin{array}{l}\text { Egy betegre jutó } \begin{array}{c}\text { konzultációk } \\
\text { (szakorvossal, új szakorvosi javaslatot generáló } \\
\text { figyelírásokat }\end{array} \\
\end{array}$ & 0,062 & 0,000 \\
\hline Betegek életkora & 0,174 & 0,001 \\
\hline Betegek életkorának a négyzete & $-0,272$ & 0,000 \\
\hline
\end{tabular}

Forrás: saját szerkesztés a Doktorinfo és az OEP adatbázisa alapján.

A lineáris regresszió eredménye alapján, azt a fontos következtetést vonhatjuk le, hogy a gyógyszerköltségre szignifikánsan hat, hogy a betegek szoros vagy gyenge kapcsolatban kezelték, azaz a kapcsolat szorosságának egyértelmü hatása van a 
gyógyszerköltségre. Szoros kapcsolatban kezelt betegek esetében szignifikánsan alacsonyabb a gyógyszerköltség, mint a gyenge kapcsolat kezeltek esetében.

Eredményeim értelmében a női betegeknek szignifikánsan magasabb a gyógyszerköltsége, mint a férfi betegeknek. A cukorbetegség súlyosságának a bétája is pozitív, amely azt jelenti, hogy a szövődményben szenvedő betegeknek szignifikánsan magasabb a gyógyszerköltségük, mint a szövődmény menteseknek. A terápia jellegének is hatása van a gyógyszerköltségre, hiszen inzulin terápia esetén szignifikánsan magasabb a gyógyszerköltség.

Az intuíciónkkal megegyezően minél magasabb a receptek illetve a szakorvossal folytatott konzultációk száma, annál magasabb költség merül fel. A betegek életkorának bétája pozitív, azaz minél idősebb egy beteg, annál magasabb a gyógyszerköltsége; a kor négyzet változó bétája negatív, ami azt jelenti, hogy a beteg életkorának a hatása a gyógyszerköltségre egy bizonyos kor után már kevésbé növekszik.

Fontos kiemelni, hogy a Quan-féle módosított Charlson társbetegség index hatása kétváltozós lineáris regresszió esetében pozitív, azaz minél több társbetegsége van egy betegnek, annál magasabb a gyógyszerköltség. Többváltozós modell esetében a béta előjele ugyan negatívra $(-0,009)$ változik, de maga a változó nem lesz szignifikáns. Mindennek oka az, hogy nem lineáris a kapcsolat a gyógyszerköltség és a beteg egészségi állapota között.

Összefoglalásképp jelen szakasz eredményei alapján kijelenthetem, hogy a gyógyszerköltségre szignifikáns hatással van, hogy szoros vagy gyenge kapcsolatban kezelik az adott beteget, azaz a szoros kapcsolatban kezelt betegek esetében alacsonyabb gyógyszerköltség merül fel, azonos egészségi állapot mellett.

\subsubsection{Szoros és gyenge kapcsolatok jellemzői}

Jelen szakaszban arra a kérdésre keresem a választ, hogy melyek azok a jellemzők, amelyek meghatározzák az orvosok közötti szoros kapcsolatokat. Az előző szakasz alapján arra a következtetésre jutottam, hogy azonos egészségi állapot mellett alacsonyabb gyógyszerköltség merül fel a szoros háziorvosi-szakorvosi kapcsolatban 
kezelt betegek esetében. Felmerül a kérdés, hogy vajon melyek azok az orvos tulajdonságok, amelyek mentén kialakulnak ezek a kapcsolatok.

Az eredményeket részben befolyásolja, hogy a háziorvosoknak a területileg illetékes szakorvosok közül kell választania. Véleményem szerint, azonban, ha több szakorvos közül választhat a háziorvos, akkor az elérhető szakorvosok közül képes hozzá hasonlóbbat választani.

A 12. táblázatban a szoros és a gyenge háziorvosi és szakorvosi kapcsolatban lévő orvosok közötti azonosságokat és különbségeket vizsgálom.

A 12. táblázat alapján szignifikáns eltérés tapasztalható a szoros és gyenge kapcsolatok között a szakorvosok és a háziorvosok nemi összetétele alapján. Sokkal kevesebb az azonos nemü orvosok közötti szoros kapcsolat, mint a különböző nemüek közötti. E tulajdonság mentén el kell, hogy utasítsam a hipotézisemet: inkább az ellenkező nemü orvosok között alakul ki szoros kapcsolat.

Szignifikáns eltérés tapasztalható a szakvizsgák számának különbségében; sokkal több szoros kapcsolat alakul ki, ha kisebb a szakvizsgák száma közötti eltérés. A homofília ez esetben jelen van az orvosok között, jobban szeretnek olyan orvosok együtt dolgozni, akikkel nincs nagy eltérés a szakvizsgáik száma között.

Ezenfelül a 12. táblázat eredményei arra is rávilágítottak, hogy minél régebb óta dolgoznak együtt, és minél közelebb van egymáshoz a háziorvos és a szakorvos rendelője, annál nagyobb eséllyel alakul ki közöttük szoros kapcsolat.

A szoros és a gyenge háziorvosi-szakorvosi kapcsolatok között nem tapasztalható szignifikáns különbség az orvosok életkorában, az egyetemi diploma megszerzésének helyében, és a megszerzésétől eltelt időben. A háziorvosoknak nem számít tehát, hogy a szakorvos hány éves, illetve hogy hol végezte az orvosi egyetemet. A területi illetékesség és az együttmüködés hossza az, ami hatással van a döntésükre. 
12. táblázat - Szoros és gyenge háziorvosi-szakorvosi kapcsolatban lévő orvosok azonossága/különbözősége

\begin{tabular}{|c|c|c|c|}
\hline Megnevezés & $\begin{array}{l}\text { Felső } \\
20 \%\end{array}$ & $\begin{array}{l}\text { Alsó } \\
20 \%\end{array}$ & $\begin{array}{c}\text { p- érték } \\
(\%)\end{array}$ \\
\hline $\begin{array}{l}\text { Nem megoszlása (\%) } \\
\text { férfi-férfi } \\
\text { nö-nö } \\
\text { férfi- nő }\end{array}$ & $\begin{array}{l}25,67 \\
49,92 \\
24,41\end{array}$ & $\begin{array}{l}27,40 \\
53,52 \\
19,08\end{array}$ & 0,52 \\
\hline $\begin{array}{l}\text { Életkor megoszlásának eltérése (\%) } \\
0-5 \\
6-10 \\
11-15 \\
16-20 \\
21-25 \\
26-\end{array}$ & $\begin{array}{r}29,79 \\
23,93 \\
19,73 \\
13,07 \\
6,81 \\
6,66 \\
\end{array}$ & $\begin{array}{r}26,60 \\
23,91 \\
19,40 \\
15,04 \\
8,87 \\
6,18 \\
\end{array}$ & 17,50 \\
\hline $\begin{array}{l}\text { Egyetemi végzettség helyének megoszlása (\%) } \\
\text { azonos } \\
\text { nem azonos }\end{array}$ & $\begin{array}{l}59,11 \\
40,89\end{array}$ & $\begin{array}{l}55,82 \\
44,18\end{array}$ & 9,42 \\
\hline $\begin{array}{l}\text { Egyetemi végzés éve közötti különbség } \\
\text { megoszlása (\%) } \\
0-5 \\
6-10 \\
11-15 \\
16-20 \\
21-25 \\
26-\end{array}$ & $\begin{array}{r}29,24 \\
24,09 \\
19,81 \\
12,12 \\
7,13 \\
7,61 \\
\end{array}$ & $\begin{array}{r}26,13 \\
22,80 \\
19,71 \\
15,99 \\
8,31 \\
7,05\end{array}$ & 5,57 \\
\hline $\begin{array}{l}\text { Szakvizsgák száma közötti különbség } \\
\text { megoszlása (\%) } \\
0 \\
1 \\
2 \\
\end{array}$ & $\begin{array}{l}35,66 \\
46,20 \\
18,15\end{array}$ & $\begin{array}{l}30,01 \\
50,36 \\
19,64\end{array}$ & 1,03 \\
\hline $\begin{array}{l}\text { Együittmüködés hosszának megoszlása (\%) } \\
0-10 \\
11-20 \\
21-30 \\
31-40 \\
41-\end{array}$ & $\begin{array}{r}5,86 \\
36,93 \\
43,03 \\
12,92 \\
1,27\end{array}$ & $\begin{array}{r}9,34 \\
42,60 \\
35,47 \\
11,80 \\
0,79\end{array}$ & 0,00 \\
\hline 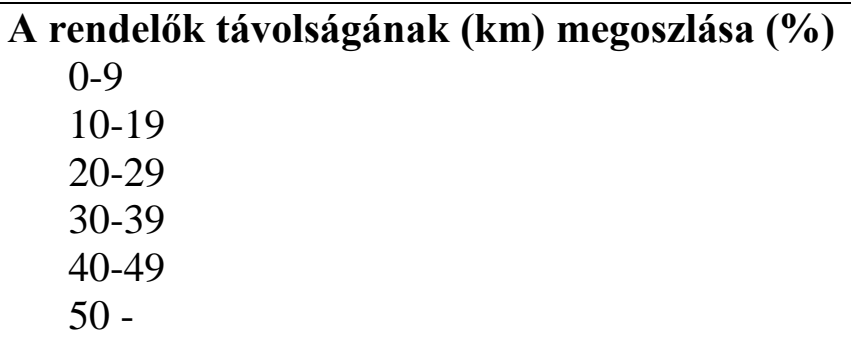 & $\begin{array}{r}57,22 \\
20,00 \\
12,86 \\
5,87 \\
2,62 \\
1,43\end{array}$ & $\begin{array}{r}18,37 \\
18,84 \\
15,76 \\
13,38 \\
9,82 \\
23,83\end{array}$ & 0,00 \\
\hline
\end{tabular}

Forrás: saját szerkesztés a Doktorinfo, ENKK, Google Maps adatbázisa alapján. 
A harmadik hipotézisemet, nevezetesen azt hogy a szoros kapcsolatban álló orvosok hasonlóak, el kell hogy vessem. Szoros kapcsolat az eltérő nemü, egymáshoz közel található, régóta kapcsolatban álló orvosok között alakul ki. A homofília az orvosok szakvizsgáinak vonatkozásában jelent csak meg, a többi esetben nem, így az előzetesen várt eredményeknek ellentmondó válaszokat kaptam.

Az ellentmondó eredménynek lehet számos oka, például hogy a betegek választanak szakorvost nem a háziorvosok, vagy a területi illetékesség miatt nincs a háziorvosok közelében hasonló jellemzőkkel rendelkező szakorvos, vagy a szoros és gyenge kapcsolatok kialakítása során csak hazánkban nem jelentkezik a homofília. Ezeknek a lehetséges okoknak a feltárásárára célszerü jobban megvizsgálni a szoros és gyenge kapcsolatban lévő orvosok jellemzőit, illetve a kis és közepes méretü településeken lévő szoros és gyenge kapcsolatokat.

\subsubsection{Szoros és gyenge kapcsolatban lévő orvosok jellemzői}

A 2.2.1. szakaszban megállapítottam, hogy a betegek azonos egészségi állapota mellett alacsonyabb gyógyszerköltséggel jár együtt, ha a beteget szoros háziorvosi-szakorvosi kapcsolatban együttmüködő orvosok kezelik. Az előző szakaszban pedig arra a megállapításra jutottam, hogy azok az orvosok állnak egymással szoros kapcsolatban, akiknek a rendelőjük közel helyezkedik el egymáshoz, régóta dolgoznak együtt, és kicsi a szakvizsgáik száma közötti különbség. Felmerül a kérdés, hogy a szoros kapcsolatban lévő háziorvosoknak illetve szakorvosoknak külön-külön milyen közös szakmai és szocio-demográfiai jellemzőik vannak. Ezekre a kérdésekre keresem a választ a jelen szakaszban.

A H4 hipotézis két alhipotézisböl tevődik össze. Egyrészt megvizsgálom, hogy a koncentrált beutalási struktúrával rendelkező háziorvosok mely jellemzőikben különböznek a nem a koncentrált beutalási struktúrával rendelkező háziorvosoktól (H4a), másrészt megvizsgálom, hogy a preferált szakorvosok jellemzői különbözneke a nem preferált szakorvosoktól (H4b). 


\subsubsection{Háziorvosok}

Jelen pontban a koncentrált és nem koncentrált beutalási struktúrával rendelkező háziorvosok definíciójára - amely a 2.1.5.2. pontban található - építem az elemzésemet, azaz a különböző szorosságú kapcsolatot létesítő háziorvosok jellemzőinek eltérését vizsgálom.

A 13. táblázatban a felső ötödben és az alsó ötödben lévő koncentrált és nem koncentrált beutalási struktúrával rendelkező háziorvosok jellemzőit hasonlítottam össze. A koncentrált és nem koncentrált beutalási struktúrával rendelkező háziorvosok rendelöjének városméretében szignifikáns eltérés áll fent, amely feltehető oka, hogy egy adott háziorvos környezetében elérhető szakorvosok száma nagyon különböző lehet. A fővárosban a háziorvosok 3,8\%-a, nagyvárosokban 1,3\%-a, a közepes méretü városokban 7,0\%-a, míg az egyéb településeken 87,97\%-a szoros kapcsolatban áll a szakorvosokkal. A fóvárosban 20,8\%, nagyvárosokban 39,6\%, a közepes méretű városokban $0,6 \%$, míg az egyéb településeken 38,99\% gyenge kapcsolatban áll a szakorvosokkal.

A koncentrált és nem koncentrált beutalási struktúrával rendelkező háziorvosok között nincs szignifikáns különbség a nemben, életkorban, szakvizsgák számában, szakmai tapasztalatban, illetve jelenlegi munkahelyeken eltöltött években. A statisztikai eredmények alapján az a következtetés vonható le, hogy a koncentrált és nem koncentrált beutalási struktúrával rendelkező háziorvosok végzettségük helye és a rendelőjük városméretében különböznek szignifikánsan egymástól.

A koncentrált beutalási struktúrával rendelkező háziorvosok között több a Budapesten (szoros: 27,2\%, gyenge: 23,3\% kapcsolat), a Szegeden (szoros: 17,7\%, gyenge: 5,7\% kapcsolat), Pécsen (szoros: 22,2\%, gyenge: 19,5\%) diplomázott orvos, még sokkal kevesebb a Debrecenben (szoros: 17,7\%; gyenge: 44,0\% kapcsolat) és külföldön (szoros: 15,2\%; gyenge: 7,55\% kapcsolat) végzett háziorvos. 


\section{3. táblázat - A koncentrált és nem koncentrált beutalási struktúrával rendelkező háziorvosok összehasonlítása}

\begin{tabular}{|c|c|c|c|}
\hline Megnevezés & $\begin{array}{l}\text { Felsö } \\
20 \%\end{array}$ & $\begin{array}{l}\text { Alsó } \\
20 \%\end{array}$ & $\begin{array}{c}\text { p-érték } \\
(\%)\end{array}$ \\
\hline $\begin{array}{l}\text { Nem megoszlása (\%) } \\
\text { férfi } \\
\text { nő }\end{array}$ & $\begin{array}{l}55,70 \\
44,30 \\
\end{array}$ & $\begin{array}{l}49,69 \\
50,31 \\
\end{array}$ & 28,39 \\
\hline $\begin{array}{l}\text { Életkor megoszlása (\%) } \\
30-39 \\
40-49 \\
50-59 \\
60-69 \\
70-79\end{array}$ & $\begin{array}{r}6,33 \\
25,32 \\
33,54 \\
25,95 \\
8,86\end{array}$ & $\begin{array}{r}12,58 \\
18,24 \\
35,22 \\
27,04 \\
6,92\end{array}$ & 23,33 \\
\hline $\begin{array}{l}\text { Egyetemi végzettség helyének megoszlása (\%) } \\
\text { Budapest } \\
\text { Debrecen } \\
\text { Szeged } \\
\text { Pécs } \\
\text { külföld }\end{array}$ & $\begin{array}{l}27,22 \\
17,72 \\
17,72 \\
22,15 \\
15,19\end{array}$ & $\begin{array}{r}23,27 \\
44,03 \\
5,66 \\
19,50 \\
7,55\end{array}$ & 0,00 \\
\hline $\begin{array}{l}\text { Szakvizsgák számának megoszlása (\%) } \\
1 \\
2 \\
3 \\
4 \text { - }\end{array}$ & $\begin{array}{r}39,24 \\
48,10 \\
9,49 \\
3,16 \\
\end{array}$ & $\begin{array}{r}39,62 \\
40,25 \\
18,24 \\
1,89 \\
\end{array}$ & 11,22 \\
\hline $\begin{array}{l}\text { Városméret megoszlása (\%) } \\
\text { Főváros } \\
\text { Nagyváros (100e főnél nagyobb) } \\
\text { Közepes település (40-100e népességü) } \\
\text { Kisváros ( -40e fónél kisebb népességü) }\end{array}$ & $\begin{array}{r}3,80 \\
1,27 \\
6,96 \\
87,97 \\
\end{array}$ & $\begin{array}{r}20,75 \\
39,62 \\
0,63 \\
38,99 \\
\end{array}$ & 0,00 \\
\hline $\begin{array}{l}\text { Szakmai tapasztalat (években) megoszlása (\%) } \\
5-14 \\
15-24 \\
25-34 \\
35-44 \\
45-54 \\
\end{array}$ & $\begin{array}{r}6,33 \\
22,78 \\
31,01 \\
29,75 \\
10,13\end{array}$ & $\begin{array}{r}9,43 \\
18,24 \\
37,11 \\
27,67 \\
7,55\end{array}$ & 50,15 \\
\hline $\begin{array}{l}\text { Jelenlegi munkahelyen eltöltött évek számának } \\
\text { megoszlása (\%) } \\
0-9 \\
10-19 \\
20-29 \\
30-39 \\
40-\end{array}$ & $\begin{array}{r}24,05 \\
45,57 \\
13,29 \\
12,03 \\
5,06\end{array}$ & $\begin{array}{r}18,87 \\
49,06 \\
17,61 \\
10,06 \\
4,40\end{array}$ & 64,43 \\
\hline
\end{tabular}

Forrás: saját szerkesztés a Doktorinfo, az ENKK, a KSH adatbázisai alapján.

A koncentrált és nem koncentrált beutalási struktúrával rendelkező háziorvosok rendelőjének városméretében szignifikáns eltérés áll fent, amely feltehető oka, hogy 
egy adott háziorvos környezetében elérhető szakorvosok száma nagyon különböző lehet.

A fővárosban a háziorvosok 3,8\%-a, nagyvárosokban 1,3\%-a, a közepes méretü városokban 7,0\%-a, míg az egyéb településeken 87,97\%-a koncentrált beutalási struktúrával rendelkezik, és így definíció szerint szoros kapcsolatban áll a szakorvosokkal. A fővárosban 20,8\%, nagyvárosokban 39,6\%, a közepes méretü városokban 0,6\%, míg az egyéb településeken 38,99\% nem koncentrált beutalási struktúrával rendelkezik és így definíció szerint gyenge kapcsolatban áll a szakorvosokkal.

A koncentrált és nem koncentrált beutalási struktúrával rendelkező háziorvosok között nincs szignifikáns különbség a nemben, életkorban, szakvizsgák számában, szakmai tapasztalatban, illetve jelenlegi munkahelyeken eltöltött években.

Érzékenység vizsgálatot is végeztem a felső és alsó 10\%-ban illetve a felső és alsó harmadban lévő háziorvosok tulajdonságaira vonatkozóan, amely során hasonló értékek adódtak, mint ami a 13. táblázatban látható. Az érzékenységvizsgálat eredménye a 3. számú mellékletben látható. Egy változót szignifikánsnak nevezek, ha $\mathrm{p}<0,05$.

Összességében elmondható a koncentrált beutalási struktúrával rendelkező háziorvosokról, hogy kisebb településeken dolgoznak, illetve hogy Szegeden, Pécsen vagy külföldön (szomszédos keleti országokban) diplomáztak.

\subsubsection{Szakorvosok}

Jelen pontban a preferált és nem preferált szakorvosok 2.1.5.3. pontban megfogalmazott definíciójára építem az eredményeimet. Azaz azt vizsgálom meg, hogy a preferált és a nem preferált szakorvosok jellemzői között tapasztalható-e szignifikáns eltérés.

A preferált szakorvosok szignifikánsan magasabb pozícióban vannak, azaz vezető pozíciót töltenek be, mely változó szintén összefügg az életkorral. 
14. táblázat - A preferált és a nem preferált szakorvosok jellemzőinek összehasonlítása

\begin{tabular}{|c|c|c|c|}
\hline Megnevezés & Preferált & $\begin{array}{c}\text { Nem } \\
\text { preferált }\end{array}$ & $\begin{array}{c}\text { p-érték } \\
(\%)\end{array}$ \\
\hline $\begin{array}{l}\text { Nem megoszlása }(\%) \\
\text { férfi } \\
\text { nő }\end{array}$ & $\begin{array}{l}40,43 \\
59,57\end{array}$ & $\begin{array}{l}47,14 \\
52,86 \\
\end{array}$ & 42,36 \\
\hline $\begin{array}{c}\text { Életkor megoszlása }(\%) \\
30-39 \\
40-49 \\
50-59 \\
60-69 \\
70-79\end{array}$ & $\begin{array}{r}2,13 \\
19,15 \\
51,06 \\
21,28 \\
6,38\end{array}$ & $\begin{array}{r}16,43 \\
34,29 \\
28,57 \\
17,86 \\
2,86\end{array}$ & 0,50 \\
\hline $\begin{array}{l}\text { Egyetemi végzettség helyének megoszlása (\%) } \\
\text { Budapest } \\
\text { Debrecen } \\
\text { Szeged } \\
\text { Pécs } \\
\text { külföld }\end{array}$ & $\begin{array}{r}27,66 \\
27,66 \\
19,15 \\
17,02 \\
8,51\end{array}$ & $\begin{array}{r}40,71 \\
23,57 \\
10,00 \\
21,43 \\
4,29\end{array}$ & 21,89 \\
\hline $\begin{array}{l}\text { Jelenlegi munkahelyen eltöltött évek megoszlása } \\
\text { (\%) } \\
\begin{array}{l}0-9 \\
10-19 \\
20-29 \\
30-39 \\
40-\end{array}\end{array}$ & $\begin{array}{r}36,17 \\
12,77 \\
31,91 \\
12,77 \\
6,38 \\
\end{array}$ & $\begin{array}{r}44,29 \\
28,57 \\
14,29 \\
10,00 \\
2,86 \\
\end{array}$ & 2,26 \\
\hline $\begin{array}{l}\text { Városméret megoszlása (\%) } \\
\text { Főváros } \\
\text { Nagyváros (100e főnél nagyobb) } \\
\text { Közepes település (40-100e népességü) } \\
\text { Kisváros ( -40e fónél kisebb népességü) }\end{array}$ & $\begin{array}{r}3,80 \\
1,27 \\
6,96 \\
87,97 \\
\end{array}$ & $\begin{array}{r}20,75 \\
39,62 \\
0,63 \\
38,99 \\
\end{array}$ & 0,00 \\
\hline $\begin{array}{l}\text { Szakvizsgák számának megoszlása (\%) } \\
\qquad \begin{array}{l}1 \\
2 \\
3 \\
4\end{array} \\
\end{array}$ & $\begin{array}{r}46,81 \\
40,43 \\
10,64 \\
2,13 \\
\end{array}$ & $\begin{array}{r}42,14 \\
44,29 \\
12,86 \\
0,71 \\
\end{array}$ & 77,81 \\
\hline $\begin{array}{l}\text { Szakorvos beosztása }(\%) \\
\text { felsővezető beosztás } \\
\text { vezető beosztás } \\
\text { nem vezető beosztás }\end{array}$ & $\begin{array}{l}27,66 \\
44,68 \\
27,66\end{array}$ & $\begin{array}{l}19,29 \\
30,00 \\
50,71\end{array}$ & 2,27 \\
\hline 30 km belüli szakorvosok száma átlaga & 20,34 & 35,41 & $0,14 \%$ \\
\hline
\end{tabular}

Forrás: saját szerkesztés a Doktorinfo, az ENKK, a KSH, a Google Maps adatbázisai alapján. 
A H4b hipotézis eredményei a 14. táblázatban találhatóak. A preferált szakorvosokról az állapítható meg, hogy szignifikánsan idősebbek, 79\%-uk elmúlt 50 éves, míg a nem preferált szakorvosoknak csak 49\%-a tartozik ebbe a korosztályba. A preferált szakorvosok szignifikánsan idősebbek, és régóta a jelenlegi praxisukban dolgoznak. Ezek az eredmények az intuíciónak megfelelőek, hiszen minél idősebb egy orvos, annál több szakmai tapasztalattal rendelkezik, és jellemzően annál régebb óta van ugyanabban a praxisban.

A preferált szakorvosok kis vagy közepes településen dolgoznak. Ez az eredmény szintén összhangban van az intuíciónkkal, hiszen jellemzően minél kevesebb szakorvos van a környéken, annál kevesebb helyre tudja a háziorvos beutalni a betegeket, és így lesz preferált szakorvosa.

Ha a háziorvosok kevés szakorvos közül választhatnak az adott környékröl, azaz 30 kilométeren belül kevés szakorvos található, akkor könnyen kialakulnak preferált kapcsolatok.

Nincs szignifikáns különbség a preferált és nem preferált szakorvosok között nemben, egyetemi végzés helyében, szakvizsgák számában.

Az érzékenység vizsgálat során a legalább három háziorvos által preferált szakorvosokra a 14. táblázatban látható eredményekhez nagyon hasonló eredmények adódtak. Az érzékenység vizsgálat eredménye a 4. számú mellékletben található.

Összefoglalásképp elmondható, hogy a preferált szakorvosok idősebbek, amelyből következik, hogy régóta dolgoznak egy adott praxisban, magasabb beosztásúak, és jellemzően kis és közepes méretü településen praktizálnak.

\subsubsection{Kis és közepes méretü települések vizsgálata}

Felmerül a kérdés, hogy vajon csak a területi illetékesség alapján alakulnak-e ki szoros és gyenge kapcsolatok lehetnek-e kisebb településeken előre meghatározottak. Kis és közepes méretű településen dolgozó háziorvosok esetében megvizsgáltam, hogy a szoros és gyenge kapcsolatban kezelt betegek egészségi állapotában és gyógyszerköltségében van-e szignifikáns különbség. Ezen elemzés keretében a városméret változót moderáló változónak tekintem. 
Az elemzést során a háziorvosokra kiszámolt HHI koncentráltság mutatót vettem alapul. Minden háziorvos mellé hozzárendeltem a városméretet, majd az adatbázist szükítettem azokra az orvosokra, akik 100e főnél kisebb településen dolgoznak (542 háziorvos a mintában vizsgált 794 közül). Ezt követően meghatároztam, hogy a kis és közepes méretü települések esetében mely orvosok tartoznak a felső és az alsó ötödbe. Ezt követően az alsó és felső ötödbe sorolt háziorvosoknak a betegeire meghatároztam a társbetegség indexeket és a gyógyszerköltséget.

A kis és közepes méretü településen dolgozó háziorvosok betegeire kiszámolt egészségi állapot és gyógyszerköltség eredményváltozók t statisztikái a 15. táblázatban találhatóak.

15. táblázat - Kis és közepes méretü településen dolgozó háziorvosok betegeire vonatkozó egészségi állapot és gyógyszerköltség összehasonlítása

\begin{tabular}{|c|c|c|c|}
\hline Eredményváltozók & $\begin{array}{c}\text { Szoros } \\
\text { kapcsolat } \\
\text { (legfelső ötöd) }\end{array}$ & $\begin{array}{c}\text { Gyenge } \\
\text { kapcsolat } \\
\text { (legalsó ötöd) }\end{array}$ & $\begin{array}{c}p- \\
\text { érték } \\
(\%)\end{array}$ \\
\hline \multicolumn{4}{|c|}{ Betegek egészségi állapota (kivéve diabétesz) } \\
\hline Charlson társbetegség index & 0,88 & 0,91 & 16,03 \\
\hline $\begin{array}{l}\text { Quan-féle módosított Charlson } \\
\text { társbetegség index }\end{array}$ & 0,59 & 0,60 & 58,15 \\
\hline Elixhauser mérték & 1,93 & 1,96 & 30,81 \\
\hline $\begin{array}{l}\text { Alternatív társbetegség index } \\
\text { (harmadik szintủ ATC kód alapján) }\end{array}$ & 7,98 & 8,38 & 0,00 \\
\hline Gyógyszerköltség (ezer HUF) & 591,89 & 696,60 & 0,00 \\
\hline
\end{tabular}

Forrás: saját szerkesztés a Doktorinfo, az ENKK, a KSH adatbázisai alapján.

A H1 és H2 hipotézis eredményeivel teljesen megegyeznek az eredmények, azaz kis és közepes méretü településeken, ahol sokkal kevesebb szakorvossal alakíthatnak ki a háziorvosok kapcsolatot, a szoros kapcsolatban kezelt háziorvos betegeinek a gyógyszerköltsége alacsonyabb, miközben az egészségi állapotban nincs szignifikáns eltérés, kivéve az alternatív társbetegség index esetében. 


\subsection{Megbeszélés}

Jelen alfejezetben az eredményekből levonható következtetésekkel, szakpolitikai javaslatokkal és a kutatás hiányosságainak ismertetésével foglalkozom.

Empirikus kutatásom során a 2. típusú cukorbetegek közös beteggondozása során létrejövő együttmüködéseket vizsgáltam a háziorvosok és a szakorvosok között. A mintában eltér az egy háziorvos által kezelt betegek száma és szórása. Egy adott háziorvos átlagosan nyolc szakorvossal tartja a kapcsolatot, de a mintában a szórás rendkívül magas. Az együttmüködési struktúra jelentősen széttagolt. Egy-egy háziorvosi-szakorvosi kapcsolatban a közösen kezelt betegek száma nagymértékben eltér, valamint az egy háziorvosra jutó szakorvosok száma is nagyon különböző, ezért a kapcsolatokat relatív viszonyszámok alkalmazásával vizsgáltam.

A kutatásomban arra az eredményre jutottam, hogy a szoros kapcsolatban kezelt betegeknek jobb az egészségi állapota, mint a gyenge kapcsolatban kezelt betegeknek, de ez a különbség nem szignifikáns. Összességében kijelenthetjük, hogy a kapcsolatok szorosságának nincs magyarázó ereje az egészségi állapotra. Ez az eredmény összhangban van a korábbi kutatások eredményeivel. O’Connor és szerzőtársai [2008] arra jutottak, hogy a HbA1c szintet ${ }^{6} 95 \%$-ban csak a beteg jellemzők határozzák meg, így csak csekély mértékben van hatással ezen értékre a beteg ellátása, valamint az orvos jellemzők. Craven és Bland [2006] szisztematikus irodalom feldolgozásukban szintén arra a következtetésre jutottak, hogy az orvosok közötti hatékonyabb együttmüködés nem jár együtt a beteg eredményeinek javulásával. A szerzők felhívták a figyelmet arra, hogy bár van egy tendencia, amely alapján beteg egészségi állapotában javulás mutatható ki az orvosok közötti közepes vagy magas szintü együttmüködés során, de néhány tanulmány ennek ellenkezőjét igazolja, miszerint gyenge szintü együttmüködés az orvosok között szintén okozhatja a beteg egészségi állapotának javulását. Smith és szerzőtársai [2007] a közös beteggondozás során létrejövő hatékonyság javulást különböző egészségi állapotot jellemző

\footnotetext{
${ }^{6}$ A HbAc1 szint (hemoglobin A1c) azt jelzi, mekkora a vörösvérsejtekben a szőlöcukorhoz kötődött hemoglobin aránya - minél magasabb a vércukorszint, annál magasabb a HbA1c szintje is. A HbA1c az előző 6-8 hét átlagos vércukorszintjét tükrözi, a mért értékből a kezelés sikerességére lehet következtetni (Larsen és szerzőtársai [1990]).
} 
mérőszámokkal közelítették, és ők is azt találták, hogy nem minden esetben mutatható ki a konzisztens javulás.

Cukorbetegek esetében Greenhalgh [1994] és Griffin [1998] szisztematikus irodalom feldolgozásuk alapján azt a következtetést vonták le, hogy a közös beteggondozás modelljének eredményei függetlenek az egészségügyi rendszerektől. Greenhalgh [1994] kutatásában arra jutott, hogy nagyon hasonló eredmények adódnak, ha a betegeket közös beteggondozás keretében, vagy ha kórházban kezelik a cukorbetegségükkel. Griffin [1998] publikációjában hasonló konklúziót vont le, azaz nem talált különbséget a cukorbetegek halálozásában, ha kórházban, vagy ha a közös beteggondozás keretében kezelték őket. Renders és szerzőtársai [2001] cukorbetegek esetében azt elemezték, hogy a célzott beavatkozások hatékonysága hogyan javítja a betegek állapotát. A szerzők arra jutottak, hogy a komplex beavatkozások, (amely alatt a betegek oktatását és/vagy az ápolók szerepének növelését értik) nem okozták egyértelműen a betegek állapotának a javulását.

A szoros, illetve gyenge háziorvosi-szakorvosi kapcsolatban kezelt betegek gyógyszerkiadása közti különbség összhangban van Barnett és szerzőtársai [2012], Landon és szerzőtársai [2012], valamint Pollack és szerzőtársai [2013] kutatásával, amelynek értelmében azok az orvosok, akik sok beteget gondoznak közösen, alacsonyabb egészségügyi kiadást generálnak. Barnett és szerzőtársai [2012] kimutatták, hogy mind a fekvőbeteg-ellátás, mind a járóbeteg-ellátás, mind a laboratóriumi, illetve egyéb képfeldolgozással járó vizsgálatok költségeire csökkentő hatással van az orvosok közötti szoros kapcsolat. Pollack és szerzőtársai [2013] kutatásában az orvosok közötti kapcsolatok szorossága, illetve a diabéteszes betegek járóbeteg- és fekvőbeteg-ellátásának költsége, valamint a gyógyszerkiadások közötti összefüggést vizsgálták. A szerzők arra jutottak, hogy az ellátás összköltsége a kapcsolatok szorosságának növekedésével csökken, azonban a költségeket elemenként vizsgálva már azt találták, hogy a nagyobb közös betegportfólió magasabb gyógyszerköltséget eredményez. A szerzők ugyanakkor ezen, eredményeimmel ellentétes összefüggésre nem adtak magyarázatot. Fontos kiemelnem két különbséget kutatásom és a nemzetközi szakirodalom között. Egyrészt ezek a kutatások nem az alapellátás és szakellátás közötti együttmüködések vizsgálatával foglalkoztak, hiszen a korábbi szakirodalmakban ez irányú kutatást a legjobb tudomásom szerint még senki 
sem végzett. Másrészt ezek a kutatások Európán kívüli egészségügyi rendszerre vonatkoztak. Mindezen különbségek ellenére hasonló eredményre jutottak.

A szoros és gyenge kapcsolatban felmerülö gyógyszerköltség eltérésének jobb megértése céljából készítettem a kétváltozós elemzésen túlmenően többváltozós regressziós elemzést is. Ennek a statisztikai módszernek a segítségével jobban fel tudtam tárni a gyógyszerköltséget együttesen magyarázó változókat. Arra az eredményre jutottam, hogy a gyógyszerköltségre szignifikánsan hat a kapcsolat szorossága, a betegek jellemzői (nem, kor, cukorbetegségének súlyossága), és a terápia típusa (inzulin, nem inzulin).

A többváltozós regresszió eredményei alapján a továbbiakban górcső alá veszem:

- a betegek jellemzőit (nem, kor, betegség súlyossága) a szoros és gyenge kapcsolatban

- a felírt gyógyszerek összetételét a szoros és gyenge kapcsolatban, külön figyelmet fordítva a terápia jellegére.

\section{Betegek jellemzői}

A többváltozós regressziós számítás eredménye alapján a női betegek esetében szignifikánsan magasabb a gyógyszerköltség, mint a férfi betegek esetében (11. táblázat). A szoros és a gyenge kapcsolatban kezelt betegek összehasonlítása alapján azt az eredményt kaptam, hogy több a női beteg a szoros kapcsolatokban, de ez az eltérés nem szignifikáns (7. táblázat). Így véleményem szerint ez nem okozhatja a gyógyszerköltség eltérését.

A betegek életkorának szignifikáns hatása van a gyógyszerköltségre, és a szoros kapcsolatban kezelt betegek között szignifikánsan magasabb az átlagéletkor. Szoros kapcsolat esetében 66 év, míg gyenge kapcsolat esetében 64 év az átlag életkor. Ezek az eredmények egymásnak ellentmondóak lehetnek, de a betegek életkora és a gyógyszerköltség között nem lineáris, sőt nem monoton növekvő a kapcsolat. Egy-egy kiugró értéktől eltekintve átlagosan 63 évnél a legmagasabb az átlagos gyógyszerköltség. Ezt követően csökkenő mértékü. Ennek több oka lehet, például a nagyon súlyos betegek már meghaltak, vagy olyan ellátásban részesülnek, amelyről nem rendelkezem információval (járó- és fekvőbeteg ellátás). Az összes betegre nézve 
64 éves betegeknek az átlagos gyógyszerköltségük 672 e Forint, míg a 66 éveseknek 660 e Forint. Ha a szoros kapcsolatok esetében vizsgáljuk a 64 éves betegek átlagos gyógyszerköltségét akkor az 670 e Forint, míg a 66 éves betegek esetében 652 e Forint. Gyenge kapcsolat esetében a vonatkozó értékek 827 e Forint és 1075 e Forint. A gyenge kapcsolat esetében 66 évnél legmagasabb átlagosan a gyenge kapcsolatban kezelt betegek átlagos gyógyszerköltsége. A vizsgált két csoport esetében az átlagéletkor eltérése nem magyarázza a gyógyszerköltség eltérését, hiszen megvizsgáltam, hogy átlag életkoronként eltér-e a gyógyszerköltség, és arra az eredményre jutottam, hogy a szoros kapcsolatok esetében életkortól függetlenül szignifikáns az alacsonyabb a gyógyszerköltség.

A többváltozós regresszió alapján a gyógyszerköltségre szignifikáns hatással van a beteg cukorbetegségének súlyossága. A szoros és gyenge kapcsolatban kezelt betegek esetében azonban nincs szignifikáns különbség a betegségük súlyosságában, így ennek a tényezőnek nem lehet szignifikáns hatása a szoros és gyenge kapcsolatban kezelt betegek gyógyszerköltségére.

\section{Felírt gyógyszerek összetétele}

Az egy betegre jutó receptek átlagos számában a szoros illetve gyenge kapcsolatban kezelt betegek között nincs szignifikáns különbség (lásd 7. táblázat), így a gyógyszerkiadások különbözőségét máshol kell keresni. Az adatatok tüzetesebb vizsgálatát követően két olyan feltételt lehet azonosítani, melyek segítségemre lehetnek a gyógyszerkiadások különbözőségének megértésében. Az első feltétel az, hogy a készítmény fontos a betegek számára, azokat a háziorvosok rendszeresen felírják nekik: második szintü ATC kód melletti aggregálás esetén az adott készítmények az összes felírás legalább 3\%-át teszik ki. A második feltétel az, hogy második szintü ATC kód melletti aggregálás esetén a szoros illetve gyenge kapcsolatban meghatározott gyógyszerkiadás közti eltérés jelentős. Megnéztem, hogy a két különböző kapcsolattípusban a betegek arányaiban az összes gyógyszerkiadásuk mekkora hányadát fordítják az egyes gyógyszerekre, gyógyszerenként meghatároztam az arányok közötti különbségeket, majd azokra a gyógyszerekre fókuszáltam, amelyek esetében az egyes gyógyszerekre fordított összegek arányai közti különbség a felső tizedbe esett. Az ATC kódokra aggregált gyógyszerárakat az OEP PUPHA adatbázis 
alapján úgy határoztam meg, hogy a vizsgált ATC szintre kiszámoltam egy áltagos árat a Doktorinfo receptadatbázisában található készítményekre.

A fenti két feltétel mentén a gyógyszerkiadások különbözőségének négy lehetséges okát azonosítottam:

- $\quad \mathrm{Az}$ A10-es készítmények aránya az összes receptfelíráson belül igen magas, függetlenül a háziorvosi-szakorvosi kapcsolat szorosságától. A szoros kapcsolatban kezelt betegek esetében az A10-es készítmények aránya ugyanakkor kicsit alacsonyabb (27,48\%), mint a gyenge kapcsolatban kezelt betegek esetében (28,18\%). Az A10-es készítmények átlagosan azonban sokkal drágábbak (7259 Forint), mint a nem A10-es készítmények (1936 Forint). Bár a különböző kapcsolatszorosságokban kezelt betegek esetében az A10-es készítmények felírása között arányaiban csak kicsi különbség van, ez a kis különbség a gyógyszerek árában mutatkozó igen szignifikáns eltérés miatt magyarázza a gyógyszerkiadások különbözőségét.

- Az antidiabetikus terápia jellege a különböző szorosságú kapcsolatok esetében nem azonos. A gyenge kapcsolatokhoz képest a szoros háziorvosi-szakorvosi kapcsolat esetében arányaiban szignifikánsan kevesebb beteg részesül inzulinos és több orális andiabetikumos kezelésben (lásd 7. táblázat). Az orális antidiabetikum készítmények átlagosan olcsóbbak (3420 Forint), mint az inzulin (9030 Forint). Tudni kell azonban, hogy a 2. típusú cukorbetegség kezelésének leggyakoribb és elsőként alkalmazott terápiás módja a metformin, ami egy meglehetősen olcsó orális készítmény.

- A béta-receptor blokkolókat $(C 07)^{7}$, a kalcium-csatorna blokkolókat (C08) ${ }^{8}$, az analgetikumokat (NO2) és a pszicholeptikumokat (N05) ${ }^{10}$ szignifikánsan magasabb arányban írják fel a szoros háziorvosi-szakorvosi kapcsolatban kezelt betegeknek.

${ }^{7}$ Kardiovaszkuláris rendszerre ható gyógyszerek, amelyek az angina, a szabálytalan szívverés, a szívroham, a szívelégtelenség és magas vérnyomás kezelésére alkalmasak.

${ }^{8}$ Kardiovaszkuláris rendszerre ható gyógyszerek, amelyek az angina, a szabálytalan szívverés és magas vérnyomás kezelésére alkalmasak.

${ }^{9}$ Fájdalomcsillapításra alkalmas idegrendszeri gyógyszerek.

${ }^{10}$ Nyugtató hatású idegrendszeri gyógyszerek. 
Ezek a készítmények relatíve olcsóbbak, körülbelül fele annyiba kerülnek, mint más nem A10-es készítmények.

- Az $A 02^{11}$ gyógyszerek felírása szignifikánsan alacsonyabb a szoros háziorvosiszakorvosi kapcsolatban kezelt betegek esetében, mint a gyenge kapcsolatban. Ezeknek a készítményeknek az ára átlagosan 8\%-kal magasabb, mint más nem A10-es készítmények ára.

A H1 és H2 hipotézis eredményeinek megbeszélése után felmerült a kérdés, hogy ha össztársadalmi szinten költségcsökkenést eredményez a szoros háziorvosi-szakorvosi kapcsolatok létesítése, akkor milyen orvos tulajdonságok mentén alakulnak ki ezek a kapcsolatok. A szakirodalom ismertetése során arra a megállapításra jutottam, hogy a megfelelő szakpolitikai ajánlások megtételéhez fontos tudni, hogy melyek azok a tényezők, amelyek miatt kialakulnak ezek a kapcsolatok, és milyen közös és különböző jellemzőkkel rendelkeznek a szoros kapcsolatban a háziorvosok és a szakorvosok, a koncentrált és a nem koncentrált beutalási struktúrával rendelkező háziorvosok, illetve a preferált és a nem preferált szakorvosok. Ezen tulajdonságok ismertetésének a birtokában lehetőségem lesz olyan ajánlásokat tenni, amelyek elősegíthetik ezeknek a kapcsolatoknak a kialakulását, fenntartását.

Az empirikus kutatásom során a H3 hipotézisemet el kellett utasítanom, azaz nem jelenik meg a homofília a szoros kapcsolatokban együttmüködő háziorvosok és szakorvosok között. A szoros háziorvosi-szakorvosi kapcsolatokban az orvosok régóta dolgoznak együtt, és közel található a munkahelyük egymáshoz. A homofília csak korlátozott mértékben jelenik meg az orvosok szakvizsgájának számában. A háziorvosok inkább olyan szakorvoshoz utalják be a betegeiket, akiket ismernek, és akikkel régóta jól együttmüködnek. Ezen eredmények összecsengnek Barnett és szerzőtársai [2012] kutatásával, azaz a homofília nem fedezhető fel az orvos jellemzők minden csoportjában.

Ezután megvizsgáltam, hogy a koncentrált beutalási struktúrával rendelkező háziorvosok jellemzőikben különböznek-e a nem koncentrált beutalási struktúrával

\footnotetext{
11 Tápcsatorna és a gyomorsavval kapcsolatos betegségek kezelésére szolgáló gyógyszerek.
} 
rendelkező háziorvosoktól, illetve a preferált szakorvosok jellemzőikben különböznek-e a nem preferált szakorvosoktól.

Arra az eredményre jutottam, hogy a koncentrált beutalási struktúrával rendelkező háziorvosok kisebb településen dolgoznak, és az egyetemi végzés helyének is szerepe van. A háziorvosoknak valószínüleg a kisebb településeken kevesebb a választási lehetősége. A preferált és a nem preferált szakorvosok összehasonlítása esetében arra jutottam, hogy preferált szakorvosok idősebbek, több szakmai tapasztalattal rendelkeznek, régóta dolgoznak az adott praxisban, kis vagy közepes méretü településen, vezető vagy főorvosi pozíciót töltenek be, kevés szakorvos található a környékükön. Mindezek alapján az a következtetés vonható le, hogy a háziorvosoknak és a betegeknek fontos a szakorvos szakmai tapasztalata; szakmai hírneve (főorvos, vezető beosztás) beleértve azt is, hogy azért van hírneve, mert régebb óta van az adott praxisban.

Ez az eredmény az intuíciómmal teljesen azonos, hiszen minél régebb óta dolgoznak az orvosok együtt, annál jobban ismerik egymás kezelési módját, tudják, hogy bátran ajánlhatják egymást, és ki tudott közöttük alakulni egy hatékony kommunikáció. A rendelök közötti távolság a beteg számára nagyon fontos tényezö, hiszen sokan nem tudnak, vagy nem akarnak messzire utazni a szakorvoshoz. A harmadik jelentős tényező, amely alapján az egymáshoz közeli orvosok között kialakulnak a szoros kapcsolatok, az a területi ellátási kötelezettség. A gyenge kapcsolatok esetében magas $(28,82 \%)$ az 50 kilométernél távolabb található rendelők közötti távolság. Ezekben az esetekben valószínűleg a beteg a szabad orvosválasztás lehetősége miatt saját maga által valamiért jól ismert vagy mások által ajánlott szakorvost keres fel a területileg illetékes szakorvos helyett. Ezekben az esetekben szinte biztosan nem ismerheti a háziorvos az adott szakorvost, és a közös beteggondozás csupán teoretikusan állhat fent.

A háziorvosok és a szakorvosok közötti kapcsolatok kialakulásában fontos szerepet játszik a területi illetékesség. A területileg illetékes szakorvosok közül pedig azokat választják a háziorvosok, akikkel már régóta dolgoznak együtt. Eredményeim fényében úgy látszik tehát, hogy nem a homofília áll a háziorvosok döntése mögött, hanem inkább a szabályozó által kialakított környezet. Így felmerült a kérdés, hogy ha csak kis és közepes méretü településeken dolgozó háziorvosokra végeztem volna el a 
kutatásomat, akkor is hasonló eredmények adódnak-e volna az egészségi állapotra és a gyógyszerköltségre.

A kis és közepes méretü településen dolgozó háziorvosokra elvégezve az elemzést, azt az eredményt kaptam, hogy ahol kevesebb a rendelkezésre álló szakorvos, ott tényleg átlagosan több szoros kapcsolat tud kialakulni, mintha az egész országra nézném az eredményeket. A mintában található 794 háziorvos közül 158 háziorvosnak koncentrált a beutalási struktúrája, amelyből csak hat budapesti háziorvos van, miközben a nem koncentrált beutalási struktúrával rendelkezö háziorvosok esetében ezek az arányok megfordulnak.

A kis és közepes méretü településen dolgozó koncentrált beutalási struktúrával rendelkező háziorvosok betegeinél nincs szignifikáns különbség a betegek egészségi állapotában miközben szignifikánsan alacsonyabb a gyógyszerköltség. Azt a következtetést vonhatjuk le, hogy ahol kevesebb a rendelkezésre álló szakorvos ott is igaz, hogy a szorosan együttmüködő orvosok társadalmi szinten költségcsökkenést érhetnek el. Nem igaz tehát, hogy kizárólag a területi illetékesség alapján alakulnak ki a szoros kapcsolatok. Valamint nem adódnak más eredmények kis és közepes méretü településeken, ahol sokkal kevesebb az elérhető szakorvos, mint az országos adatbázist tartalmazó elemzésben.

\subsubsection{Szakpolitikai javaslatok}

Kutatásom legfőbb egészség-gazdaságpolitikai vonatkozása a betegek számára biztosított szabad orvos-, illetve egészségügyi szolgáltató választással hozható összefüggésbe, amely számos fejlett országban, köztük az Egyesült Királyságban illetve Hollandiában a közelmúltban bevezetésre került. Amennyiben a betegek mindenféle korlátozás nélkül, teljesen szabadon választhatják ki szakorvosukat, úgy előfordulhat, hogy a háziorvosoknak a korábbinál jóval több szakorvossal kell a betegek közös gondozása érdekében együttmüködniük. Kutatásom során bebizonyítottam, hogy azon háziorvosok betegeinek gyógyszerkiadása magasabb, ahol a háziorvos arányaiban több szakorvossal gondoz közösen beteget. Mindezek alapján az egészségügyi stratégiaalkotóknak inkább a korlátozottan szabad orvosválasztás irányába kellene elmozdulniuk, hangsúlyt helyezve a magas színvonalú egészségügyi oktatásra és a technikai infrastruktúra fejlesztésére. Amennyiben a betegek néhány 
közeli kiváló szakorvos közül választhatnak, úgy az előnyös lenne a betegnek az utazási költség és az időráfordítás csökkenése miatt, miközben össztársadalmi szinten a gyógyszerkiadás csökkenthető. A háziorvosokat célszerü lenne központilag különböző ösztönzési rendszerek segítségével a szoros szakorvosi kapcsolatok irányába terelni.

\subsubsection{Kutatás hiányosságai}

Kutatásomnak számos olyan hiányossága van, amelyek kiküszöbölése további kutatások alapját képezheti.

Az első, hogy a háziorvosok és a szakorvosok közötti formális szakmai kapcsolatokat receptadatok alapján határoztam meg, amely kapcsolatazonosítási technikát Barnett és szerzőtársai [2011] egy korábbi kutatásukban validálták. A betegek közös gondozása vélhetően az orvosok között fokozott információcserével és interaktív kommunikációval jár együtt; minél több beteget gondoznak közösen az orvosok annál interaktívabb a kapcsolatuk, ami a betegek ellátásának jobb koordinációját eredményezi. Azt ugyanakkor nem tudjuk, hogy a közös beteggondozás révén létrejött orvosok közötti formális kapcsolatokban milyen információk illetve viselkedésminták cserélnek gazdát, feltéve, hogy egyáltalán történik valamilyenfajta csere. A kutatásom során alkalmazott feltevések nagy valószínüséggel megállják a helyüket a valóságban: több közösen gondozott beteg vélhetően intenzívebb kommunikációval jár együtt. Mindazonáltal az, hogy két orvos számos beteget gondoz közösen, nem feltétlenül jelenti azt, hogy az orvosok minden egyes páciensröl értekeznek egymás között.

Kutatásom második hiányossága az, hogy a feltárt szignifikáns összefüggések mögötti ok-okozati kapcsolatról tudásom meglehetősen korlátozott, az általam feltételezett irány igazolása további, kvalitatív vizsgálatokat igényelne.

A harmadik hiányosság az, hogy a betegek egészségi állapotának mérésére szolgáló társbetegség indexek nem teszik lehetővé, hogy megállapítsuk, hogy a szoros háziorvosi-szakorvosi kapcsolatokban a betegek valóban jobb egészségügyi ellátásban részesültek-e, és hogy az ellátással elégedettebbek voltak-e mint a többiek. Az egészségi állapot mérésére csak egy változót vettem figyelembe, és nem ismerem a 
HbAc1 szintet, amely a diabéteszes betegek állapotának legfontosabb és legjobb mérőszáma, valamint nem vettem figyelembe a betegek elégedettségét sem.

A negyedik hiányosság, hogy a gyógyszerköltség a teljes betegellátási költségnek csak egy részét teszi ki, a betegek egyéb ellátási költségeinek vizsgálata, mint például a járó- és fekvőbeteg ellátás során felmerülő költségek elemzése, adatok hiányában meghaladta a jelen kutatás kereteit.

Az ötödik hiányosság, hogy csak egy szakterületre fókuszáltam (belgyógyászatendokrinológia) a kutatás során. További kutatási irány a jövőben, hogy az eredményeim érvényességét más szakterületekre is megvizsgáljam.

A hatodik hiányosság, hogy a háziorvosok és a szakorvosok közötti szakmai kapcsolatok időben változhatnak, ami miatt a jövőben longitudinális elemzések is fontosak lennének.

A hetedik hiányosság, hogy csak azoknak a háziorvosoknak ismerem a felírásait, akik önkéntesen beküldték a recept adataikat, így lehetséges, hogy az általam nem ismert háziorvosok más együttmüködési struktúrával jellemezhetőek. 


\section{Összefoglalás}

Az egészségügyben megjelenő hálózatok vizsgálatával foglalkoztam a disszertációmban. Az egészségügyben fennálló és müködő kapcsolatrendszerek sokszínüsége és összetettsége miatt leszükítettem a kutatási irányomat az egészségügyi rendszeren belüli hálózatok szakemberek közötti kapcsolatokra vonatkozó részterületére. Kutatásomnak az volt a célja, hogy megvizsgáljam, a különböző egészségügyi szakemberek közötti kapcsolatoknak, nevezetesen a háziorvosok és a szakorvosok együttmüködésének van-e hatása a betegek egészségi állapotára és az ellátás költségére.

A betegek, a háziorvosok, és a szakorvosok eredményes együttmüködése az egész egészségügyi rendszer hatékonyságának egyik sarokköve. Fokozottan igaz ez a közös beteggondozás esetére, ahol a krónikus betegeket a háziorvosok és a szakorvosok együttmüködve látják el. A közös beteggondozás megjelenési formái közül a szakellátásban létrejövő, azaz a háziorvosok és szakorvosok közötti kapcsolatokat vettem górcső alá. Keating és szerzőtársai [1998] definícióját használtam a formális kapcsolatok meghatározására, azaz két orvos között akkor létezett ilyen kapcsolat, ha a háziorvos beutalta a betegét a szakorvoshoz. A kutatás során a közös beteggondozásban résztvevő orvosok közötti szakmai kapcsolatokat a recepten szereplő egyedi adatok segítségével ragadtam meg. Korábban csak néhány tanulmány vizsgálta az orvosok közötti kapcsolatokat kvantitatív módszerrel, amelyek arra az eredményre jutottak, hogy minél több az orvosok által közösen gondozott beteg, annál költséghatékonyabb az ellátás.

A disszertációm elsősorban abban mutat túl a korábbi néhány kutatásokon, hogy a felmerülő gyógyszerköltség mellett a betegek egészségi állapotát is figyelembe vettem, amelyet a hármas célrendszer tesz indokolttá. Másodsorban Európában korábban nem született kutatás ezen kérdések vizsgálatára.

Az első két hipotézisem együttes vizsgálata során arra a következtetésre jutottam, hogy az orvosok közötti kapcsolat szorossága nem áll összefüggésben a diagnosztizált és kezelt társbetegségek számával, azaz nem találtam bizonyítékot arra vonatkozóan, hogy a kapcsolat-szorosságnak hatása lenne a beteg egészségi állapotára. Ugyanakkor azt tapasztaltam, hogy a betegellátás jobb koordinációja alacsonyabb ellátási 
költséggel jár együtt: a szoros háziorvosi-szakorvosi kapcsolatban kezelt betegek gyógyszerkiadása jóval alacsonyabb, mint a gyenge háziorvosi-szakorvosi kapcsolatban kezelteké.

A kutatásom első két hipotézise értelmében a szoros háziorvosi-szakorvosi kapcsolatban ellátott betegeknél költségcsökkenés érhető el azonos egészségi állapot mellett. Így ezeknek a kapcsolatnak a támogatása, megértése mindenkinek az érdeke kell, hogy legyen. A harmadik és a negyedik hipotézis keretében ezen kapcsolatokat vetettem tüzetesebb vizsgálat alá. Arra az eredményre jutottam, hogy a szoros kapcsolatban álló orvosok között nem jelenik meg a homofília. Szoros kapcsolat a háziorvosok és a szakorvosok között jellemzően eltérő nemü, azonos tudományos elkötelezettségű, egymáshoz közel található rendelővel rendelkező orvosok között alakul ki. A koncentrált beutalási struktúrával rendelkező háziorvosokról megállapítottam, hogy kisebb településeken dolgoznak, illetve hogy Szegeden, Pécsen vagy külföldön (szomszédos keleti országokban) diplomáztak. A preferált szakorvosok jellemzően idősebbek, több szakmai tapasztalattal rendelkeznek, régóta dolgoznak az adott praxisban, és kis vagy közepes méretü településen, kórházban vagy járóbeteg szakellátáson dolgoznak, vezető vagy föorvosi pozíciót töltenek be, olyan környéken, ahol kevés szakorvos található. Összességében elmondható, hogy a háziorvosok nem a hasonló jegyekkel rendelkező szakorvosokkal dolgoznak együtt, hanem a földrajzi közelség és az elérhető szakorvosok köre mentén alakulnak ki szoros háziorvosi-szakorvosi kapcsolatok.

Fontos kiemelnem, hogy a közepes és kis településeken, ahol sokkal kevesebb az elérhető szakorvosok száma és a területi illetékesség alapján alakulnak ki általában az említett orvosok közötti kapcsolatok, az itt dolgozó orvosok gyakorlatát vizsgálva is azt a következtetést vonhatjuk le, hogy a szoros kapcsolatban kezelt betegek egészségi állapotában nincs szignifikáns különbség, míg alacsonyabb a gyógyszerköltség.

A kutatásom föbb egészséggazdaságtani következtetései az, hogy társadalmi szinten alacsonyabb gyógyszerkiadást eredményez, ha a közös betegellátási struktúra töredezettsége alacsony, amely úgy érhető el, hogy a háziorvosok relatíve kevés szakorvossal állnak szakmai kapcsolatban. A hatékonyabb betegkoordinációval együtt járó pénzügyi megtakarítás realizálásának illetve megtartásának egyik módja az, ha az 
egészségügyi stratégiaalkotók és politikai döntéshozók a teljesen szabad orvosválasztás helyett a korlátozottan szabad orvosválasztás mellett teszik le voksukat.

Az egészségügyi hálózatok rendkívül komplex rendszert alkotnak, ezen rendszer megértéséhez igyekeztem disszertációmmal hozzájárulni. 


\section{MELLÉKLETEK}

1. számú melléklet: Charlson társbetegség index egyes betegségtípusainak megoszlása különböző mintákban (\%)

\begin{tabular}{|c|c|c|c|c|c|}
\hline \multirow[b]{2}{*}{$\begin{array}{c}\text { Charlson társbetegség } \\
\text { index }\end{array}$} & \multirow{2}{*}{$\begin{array}{l}\text { Keresztúri } \\
n=31070\end{array}$} & \multicolumn{2}{|c|}{$\begin{array}{c}\text { Meyers és szerzőtársai } \\
{[2014]}\end{array}$} & \multicolumn{2}{|c|}{$\begin{array}{c}\text { Lix és szerzőtársai } \\
{[2013]}\end{array}$} \\
\hline & & $\begin{array}{c}\text { Magas } \\
\text { költséggel } \\
\text { rendelkező } \\
\text { részminta } \\
\text { (felső 20\%), } \\
n=344019\end{array}$ & $\begin{array}{c}\text { Alacsony } \\
\text { költséggel } \\
\text { rendelkezó } \\
\text { részminta } \\
\text { (alsó } 80 \% \text { ), } \\
n=1376022\end{array}$ & $\begin{array}{l}\text { Minta 1, } \\
\mathrm{n}=29058\end{array}$ & $\begin{array}{l}\text { Minta 2, } \\
\mathrm{n}=41925\end{array}$ \\
\hline AIDS/HIV & 0,0 & 0,5 & 0,1 & $<0,1$ & $<0,1$ \\
\hline $\begin{array}{l}\text { Malignus lymphoma, } \\
\text { leukémia }\end{array}$ & 2,4 & 15,7 & 5,9 & 5,5 & 5,8 \\
\hline Cerebrovascularis betegség & 23,2 & 15,6 & 6,3 & 5,5 & 4,7 \\
\hline COPD & 13,3 & 26,1 & 12,6 & 14,0 & 13,7 \\
\hline Kongesztív szívelégtelenség & 15,5 & 16,2 & 4,7 & 8,0 & 8,1 \\
\hline Dementia & 0,9 & 1,4 & 0,7 & 0,8 & 0,9 \\
\hline Hemiplegia vagy paraplegia & 0,2 & 1,5 & 0,2 & 0,6 & 0,4 \\
\hline $\begin{array}{l}\text { Szolid tumor, illetve szolid } \\
\text { tumor metasztázissal }\end{array}$ & 0,3 & 3,6 & 0,4 & 1,3 & 1,8 \\
\hline Májbetegség (enyhe fokú) & 2,0 & 1,6 & 0,3 & 0,6 & 0,6 \\
\hline $\begin{array}{l}\text { Májbetegség (mérsékelten } \\
\text { súlyos vagy súlyos fokú) }\end{array}$ & 0,3 & 19,2 & 6,3 & 0,1 & 0,2 \\
\hline Myocardialis infarctus & 4,2 & 8,4 & 1,7 & 2,5 & 3,0 \\
\hline Peptikus fekélybetegség & 4,3 & 2,5 & 0,7 & 2,0 & 1,7 \\
\hline Perifériás érbetegség & 18,5 & 10,0 & 4,0 & 1,4 & 1,6 \\
\hline $\begin{array}{l}\text { Mérsékelt vagy súlyos fokú } \\
\text { krónikus vesebetegség }\end{array}$ & 1,5 & 7,6 & 1,5 & 1,9 & 3,2 \\
\hline Reumás betegségek & 1,5 & 4,4 & 1,8 & 0,8 & 0,8 \\
\hline
\end{tabular}


2. számú melléklet: Elixhauser mérték egyes betegségtípusainak megoszlása különböző mintákban (\%)

\begin{tabular}{|c|c|c|c|c|c|}
\hline \multirow[b]{2}{*}{ Elixhauser mérték } & \multirow{2}{*}{$\begin{array}{c}\text { Keresztúri } \\
n=31070\end{array}$} & \multicolumn{2}{|c|}{$\begin{array}{c}\text { Lix és szerzőtársai } \\
{[2013]}\end{array}$} & \multicolumn{2}{|c|}{ Quail et al. (2011) } \\
\hline & & $\begin{array}{l}\text { Minta 1, } \\
n=29058\end{array}$ & $\begin{array}{l}\text { Minta 2, } \\
n=41925\end{array}$ & $\begin{array}{c}\text { Teljes } \\
\text { minta, } \\
n=662423\end{array}$ & $\begin{array}{c}\text { 65+évesek } \\
\text { mintája, } \\
n=41925\end{array}$ \\
\hline AIDS/HIV & 0,0 & $<0,1$ & $<0,1$ & $<0,1$ & 0,0 \\
\hline Alkoholizmus & 0,5 & 0,4 & 0,7 & 0,7 & 0,4 \\
\hline $\begin{array}{l}\text { Vashiányos anaemia } \\
\text { vérveszteségtől }\end{array}$ & 1,1 & 0,0 & $<0,1$ & 0,1 & 0,1 \\
\hline Szívritmuszavar & 9,3 & 2,3 & 2,8 & 2,8 & 4,7 \\
\hline COPD & 13,2 & 13,9 & 13,5 & 13,5 & 14,3 \\
\hline Coagulopathy & 0,4 & 1,0 & 2,5 & 2,5 & 3,9 \\
\hline Kongesztív szívelégtelenség & 15,5 & 8,0 & 8,0 & 8,0 & 13,4 \\
\hline Egyéb anaemia & 4,4 & 0,5 & 0,8 & 0,8 & 1,3 \\
\hline Depresszió & 20,1 & 5,8 & 6,0 & 6,0 & 4,8 \\
\hline Kábítószer függőség & 0,0 & 0,3 & 0,4 & 0,4 & 0,1 \\
\hline $\begin{array}{l}\text { Folyadék és elektrolit } \\
\text { háztartás betegségei }\end{array}$ & 4,4 & 1,9 & 2,7 & 2,7 & 4,0 \\
\hline $\begin{array}{l}\text { Magas vérnyomás, } \\
\text { komplikációval }\end{array}$ & 2,7 & 0,7 & 1,0 & 1,0 & 1,5 \\
\hline $\begin{array}{l}\text { Magas vérnyomás, } \\
\text { komplikáció nélkül }\end{array}$ & 89,4 & 33,3 & 42,7 & 42,7 & 51,1 \\
\hline Hypothyroidism & 2,9 & 0,4 & 1,1 & 4,7 & 5,6 \\
\hline Májelégtelenség & 2,2 & 0,6 & 0,7 & 0,7 & 0,6 \\
\hline Lymphoma & 0,2 & 0,2 & 0,2 & 0,2 & 0,3 \\
\hline Metasztázisos szolid tumor & 0,3 & 1,3 & 1,7 & 1,7 & 2,8 \\
\hline Elhízottság & 0,4 & 0,6 & 1,0 & 1,0 & 0,9 \\
\hline $\begin{array}{l}\text { Egyéb neurológiai } \\
\text { rendellenesség }\end{array}$ & 3,5 & 1,1 & 1,2 & 1,2 & 1,3 \\
\hline Paralízis & 0,2 & 0,6 & 0,4 & 0,4 & 0,6 \\
\hline $\begin{array}{l}\text { Gyomorfekély betegség } \\
\text { (vérzés nélkül), }\end{array}$ & 3,1 & 0,3 & 0,4 & 0,4 & 0,5 \\
\hline Perifériás érbetegség & 18,5 & 1,4 & 1,5 & 1,5 & 2,2 \\
\hline Pszichózis & 0,4 & 2,4 & 2,7 & 2,7 & 4,4 \\
\hline Pulmonális szívbetegség & 0,1 & 0,7 & 0,8 & 0,8 & 1,2 \\
\hline Veseelégtelenség & 1,5 & 1,8 & 3,1 & 3,1 & 4,2 \\
\hline Rheumatoid arthritis & 1,6 & 1,9 & 1,9 & 1,9 & 2,2 \\
\hline $\begin{array}{l}\text { Szolid tumor (metasztázis } \\
\text { nélkül) }\end{array}$ & 2,1 & 5,0 & 5,4 & 5,4 & 8,8 \\
\hline Szívbillentyü-betegség & 0,7 & 1,5 & 2,2 & 2,2 & 3,1 \\
\hline Alultápláltság & 0,4 & 0,1 & 0,2 & 0,2 & 0,2 \\
\hline
\end{tabular}


3. számú melléklet: Érzékenység vizsgálat a koncentrált és nem koncentrált beutalási struktúrával rendelkező háziorvosok összehasonlítására

\begin{tabular}{|c|c|c|c|c|c|c|}
\hline Megnevezés & $\begin{array}{c}\text { Felső } \\
10 \% \\
\end{array}$ & $\begin{array}{l}\text { Alsó } \\
10 \% \\
\end{array}$ & $\begin{array}{c}\text { p-érték } \\
(\%)\end{array}$ & $\begin{array}{l}\text { Felső } \\
\mathbf{3 3 \%} \\
\end{array}$ & $\begin{array}{l}\text { Alsó } \\
\text { 33\% } \\
\end{array}$ & $\begin{array}{c}\text { p-érték } \\
(\%)\end{array}$ \\
\hline $\begin{array}{l}\text { Nem megoszlása (\%) } \\
\text { férfi } \\
\text { nő }\end{array}$ & $\begin{array}{l}55,70 \\
44,30\end{array}$ & $\begin{array}{l}50,00 \\
50,00\end{array}$ & 47,19 & $\begin{array}{l}55,68 \\
44,32\end{array}$ & $\begin{array}{l}52,45 \\
47,55\end{array}$ & 45,62 \\
\hline $\begin{array}{c}\text { Életkor megoszlása (\%) } \\
30-39 \\
40-49 \\
50-59 \\
60-69 \\
70-79\end{array}$ & $\begin{array}{r}10,13 \\
24,05 \\
36,71 \\
24,05 \\
5,06\end{array}$ & $\begin{array}{r}15,00 \\
21,25 \\
28,75 \\
28,75 \\
6,25\end{array}$ & 71,93 & $\begin{array}{r}6,82 \\
22,73 \\
34,85 \\
26,14 \\
9,47\end{array}$ & $\begin{array}{r}11,32 \\
19,25 \\
37,74 \\
25,28 \\
6,42\end{array}$ & 22,99 \\
\hline $\begin{array}{l}\text { Egyetemi végzettség helyének } \\
\text { megoszlása (\%) } \\
\text { Budapest } \\
\text { Debrecen } \\
\text { Szeged } \\
\text { Pécs } \\
\text { külföld }\end{array}$ & $\begin{array}{l}25,32 \\
17,72 \\
15,19 \\
22,78 \\
18,99\end{array}$ & $\begin{array}{r}26,25 \\
38,75 \\
5,00 \\
21,25 \\
8,75\end{array}$ & 0,96 & $\begin{array}{l}29,92 \\
21,59 \\
18,56 \\
18,18 \\
11,74\end{array}$ & $\begin{array}{r}24,53 \\
38,11 \\
7,55 \\
20,38 \\
9,43\end{array}$ & 0,00 \\
\hline $\begin{array}{l}\text { Szakvizsgák számának } \\
\text { megoszlása (\%) } \\
1 \\
2 \\
3 \\
4 \text { - }\end{array}$ & $\begin{array}{r}40,51 \\
48,10 \\
8,86 \\
2,53\end{array}$ & $\begin{array}{r}41,25 \\
45,00 \\
12,50 \\
1,25\end{array}$ & 81,92 & $\begin{array}{r}38,64 \\
44,32 \\
13,64 \\
3,41\end{array}$ & $\begin{array}{r}39,62 \\
39,62 \\
18,87 \\
1,89\end{array}$ & 24,96 \\
\hline $\begin{array}{l}\text { Városméret megoszlása (\%) } \\
1 \text { - Főváros } \\
2 \text { - Nagyváros (100e főnél } \\
\text { nagyobb) } \\
3 \text { - Közepes település (40- } \\
\text { 100e népességü) } \\
4 \text { - Kisváros ( -40e főnél } \\
\text { kisebb népességü) }\end{array}$ & $\begin{array}{r}1,27 \\
6,33 \\
91,14\end{array}$ & $\begin{array}{r}45,00 \\
1,25 \\
30,00\end{array}$ & 0,00 & $\begin{array}{r}1,14 \\
9,85 \\
80,68\end{array}$ & $\begin{array}{r}20,75 \\
32,45 \\
0,75 \\
46,04\end{array}$ & 0,00 \\
\hline $\begin{array}{l}\text { Szakmai tapasztalat } \\
\text { (években) megoszlása (\%) } \\
5-14 \\
15-24 \\
25-34 \\
35-44 \\
45-54\end{array}$ & $\begin{array}{r}10,13 \\
21,52 \\
35,44 \\
25,32 \\
7,59\end{array}$ & $\begin{array}{r}11,25 \\
20,00 \\
33,75 \\
27,50 \\
7,50\end{array}$ & 99,55 & $\begin{array}{r}6,44 \\
20,08 \\
33,71 \\
28,79 \\
10,98\end{array}$ & $\begin{array}{r}8,68 \\
18,11 \\
38,87 \\
27,17 \\
7,17\end{array}$ & 35,97 \\
\hline $\begin{array}{l}\text { Jelenlegi munkahelyen } \\
\text { eltöltött évek számának } \\
\text { megoszlása (\%) } \\
0-9 \\
10-19 \\
20-29 \\
30-39 \\
40-\end{array}$ & $\begin{array}{r}26,58 \\
48,10 \\
11,39 \\
11,39 \\
2,53\end{array}$ & $\begin{array}{r}21,25 \\
52,50 \\
16,25 \\
8,75 \\
1,25\end{array}$ & 74,95 & $\begin{array}{r}25,38 \\
42,42 \\
15,91 \\
11,36 \\
4,92\end{array}$ & $\begin{array}{r}19,25 \\
47,17 \\
18,11 \\
10,94 \\
4,53\end{array}$ & 50,30 \\
\hline
\end{tabular}


4. számú melléklet: Érzékenység vizsgálat a preferált és a nem preferált szakorvosok jellemzőinek összehasonlítására

\begin{tabular}{|c|c|c|c|}
\hline Megnevezés & $\begin{array}{c}\text { Preferált } \\
\text { (3 háziorvos által) }\end{array}$ & $\begin{array}{c}\text { Nem } \\
\text { preferált }\end{array}$ & $\begin{array}{c}\text { p-érték } \\
(\%)\end{array}$ \\
\hline $\begin{array}{l}\text { Nem megoszlása (\%) } \\
\text { férfi } \\
\text { nő }\end{array}$ & $\begin{array}{l}42,86 \\
57,14\end{array}$ & $\begin{array}{l}47,14 \\
52,86\end{array}$ & 53,29 \\
\hline $\begin{array}{c}\text { Életkor megoszlása (\%) } \\
30-39 \\
40-49 \\
50-59 \\
60-69 \\
70-79\end{array}$ & $\begin{array}{r}7,14 \\
30,95 \\
36,90 \\
20,24 \\
4,76\end{array}$ & $\begin{array}{r}16,43 \\
34,29 \\
28,57 \\
17,86 \\
2,86\end{array}$ & 23,84 \\
\hline $\begin{array}{l}\text { Egyetemi végzettség helyének } \\
\text { megoszlása (\%) } \\
\text { Budapest } \\
\text { Debrecen } \\
\text { Szeged } \\
\text { Pécs } \\
\text { külföld }\end{array}$ & $\begin{array}{r}25,00 \\
28,57 \\
17,86 \\
20,24 \\
8,33\end{array}$ & $\begin{array}{r}40,71 \\
23,57 \\
10,00 \\
21,43 \\
4,29\end{array}$ & 8,25 \\
\hline $\begin{array}{l}\text { Jelenlegi munkahelyen eltöltött évek } \\
\text { megoszlása (\%) } \\
0-9 \\
10-19 \\
20-29 \\
30-39 \\
40- \\
\end{array}$ & $\begin{array}{r}44,05 \\
15,48 \\
26,19 \\
9,52 \\
4,76 \\
\end{array}$ & $\begin{array}{r}44,29 \\
28,57 \\
14,29 \\
10,00 \\
2,86 \\
\end{array}$ & 8,06 \\
\hline $\begin{array}{l}\text { Városméret megoszlása (\%) } \\
\text { Főváros } \\
\text { Nagyváros (100e főnél nagyobb) } \\
\text { Közepes település (40-100e } \\
\text { népességü) } \\
\text { Kisváros ( -40e főnél kisebb } \\
\text { népességü) }\end{array}$ & $\begin{array}{r}3,80 \\
1,27 \\
6,96 \\
87,97\end{array}$ & $\begin{array}{r}20,75 \\
39,62 \\
0,63 \\
38,99\end{array}$ & 0,00 \\
\hline $\begin{array}{l}\text { Szakvizsgák számának megoszlása } \\
\text { (\%) } \\
1 \\
2 \\
3 \\
4\end{array}$ & $\begin{array}{r}51,19 \\
35,71 \\
9,52 \\
3,57\end{array}$ & $\begin{array}{r}42,14 \\
44,29 \\
12,86 \\
0,71 \\
\end{array}$ & 18,82 \\
\hline $\begin{array}{l}\text { Szakorvos beosztása }(\%) \\
\text { felsővezető beosztás } \\
\text { vezető beosztás } \\
\text { nem vezető beosztás } \\
\end{array}$ & $\begin{array}{l}22,62 \\
35,71 \\
41,67 \\
\end{array}$ & $\begin{array}{l}19,29 \\
30,00 \\
50,71 \\
\end{array}$ & 42,20 \\
\hline $\begin{array}{l}30 \text { km belüli szakorvosok száma } \\
\text { átlaga }\end{array}$ & 22,80 & 35,41 & 0,24 \\
\hline
\end{tabular}




\section{Hivatkozások jegyzéke}

ANDREWS, F. - HOOD, P. [2003]: Shared care: hospital, hospice, home. Pediatric Nursing. Vol. 15. No. 6. pp. 20-22. DOI: 10.7748/paed2003.07.15.6.20.c865

BALAKRISHNAN, A. - GEUNES, J. [2004]: Collaboration and Coordination in Supply Chain Management and E-Commerce. Production and Operations Management. Vol. 13. No. 1. pp. 1-2. DOI:10.1111/j.19375956.2004.tb00140.x

BARNETT, M. L. - LANDON, B. E. - O’MALLEY, A. J. - KEATING, N. L. CHRISTAKIS, N. A. [2011]: Mapping physician networks with self-reported and administrative data. Health Services Research. Vol. 46. No. 5. pp. 15921609. DOI: $10.1111 / \mathrm{j} .1475-6773.2011 .01262 . x$

BARNETT, M. L. - CHRISTAKIS, N. A. - O'MALLEY, A. J. - ONNELA, J. P. KEATING, N. L. - LANDON, B. E. [2012]: Physician patient-sharing networks and the cost and intensity of care in US hospitals. Medical Care. Vol. 50. No. 2. pp. 152-160. DOI: 10.1097/MLR.0b013e31822dcef7

BAYLISS, E. A. - ELLIS, J. L. - STEINER, J. F. [2005]: Subjective assessments of comorbidity correlate with of life health outcomes: initial validation of a comorbidity assessment instrument. Health and Quality of Life Outcomes. 3:51. DOI: $10.1186 / 1477-7525-3-51$

BERWICK, D. M. - NOLAN, T. W. - WHITTINGTON, J. [2008]: The Triple Aim: Care, Health, And Cost. Health Affairs. Vol. 27. No. 3. pp. 759-769. DOI: 10.1377/hlthaff.27.3.759

BLACKWOOD, R. [2009]: Measures of health status, quality of life and health care. HealthKnowledge. Elérhetö: http:/www.healthknowledge.org.uk/publichealth-textbook/research-methods/1c-health-care-evaluation-health-careassessment/measures-health-status. Letöltés dátuma: 2015. június 1. 
BORGATTI, S. P. - FOSTER, P. C. [2003]: The Network Paradigm in Organizational Research: A Review and Typology. Journal of Management. Vol. 29. No. 6. pp. 991-1013. DOI:10.1016/s0149-2063_03_00087-4

BOSCH, M. - FABE, M. J. - CRUIJSBERG, J. - VOERMAN, G. E. LEATHERMAN, S. - GROL, R. P. T. M. - HULSCHER, M. - WENSING, M. [2009]: Review article: effectiveness of patient care teams and the role of clinical expertise and coordination: a literature review. Medical Care Research and Review. Vol. 66. No. 6S. pp. 5S-35S. DOI: 10.1177/1077558709343295

CAMMACK, V - BYRNE, K. [2012]: Accelerating a Network Model of Care: Taking a Social Innovation to Scale. Technology Innovation Management Review. Vol. 2. No. 7. pp. 26-30.

CHAMBERS, D. - WILSON, P. - THOMPSON, C. - HARDEN, M [2012]: Social Network Analysis in Healthcare Settings: A Systematic Scoping Review. PLoS One. Vol. 7. 8:e41911. DOI: 10.1371/journal.pone.0041911

CHARLSON, M. E. - POMPEI, P. - ALES, K. L. - MACKENZIE, C. R. [1987]: A new method of classifying prognostic comorbidity in longitudinal studies: development and validation. Journal of Chronic Diseases. Vol. 40. No. 5. pp. 373-383. DOI: 10.1016/0021-9681(87)90171-8

CHIULLI, R. M. [2009]: Quantitative Analysis: An Introduction. Overseas Publishers Association. Amsterdam.

CHRISTAKIS, N. A. [2004]: Social networks and collateral health effects. British Medical Journal. 329:184. DOI: 10.1136/bmj.329.7459.184

CRAVEN, M. A. - BLAND, R. [2006]: Better practices in collaborative mental health care: an analysis of the evidence base. Canadian Journal of Psychiatry, Vol. 51. No. 6 Suppl 1. pp. 7S-72S.

CROPPER, S. - EBERS, M. - HUXHAM, C. - RING, P. S. [2008] (szerk): The Oxford Handbook of Inter-organizational Relations. Oxford University Press, Oxford. DOI: 10.1093/oxfordhb/9780199282944.001.0001 
CUNNINGHAM, F. C. - RANMUTHUGALA, G. - PLUMB, J. - GEORGIOU, A. WESTBROOK, J. I. - BRAITHWAITE, J. [2012]: Health professional networks as a vector for improving healthcare quality and safety: a systematic review. British Medical Journal Quality and Safety. Vol. 21. pp. 239-249. DOI: 10.1136/bmjqs-2011-000187

CSIZMADIA ZOLTÁN - GROSZ ANDRÁS [2011]: Innováció és együttmüködés: A kapcsolathálózatok innovációra gyakorolt hatása. Magyar Tudományos Akadémia Regionális Kutatások Központja, Pécs-Győr.

DANAEI, G. - FINUCANE, M. M. - LU, Y. - SINGH, G. M. - COWAN, M. J. PACIOREK, C. J. - EZZATI, M. [2011]: National, regional, and global trends in fasting plasma glucose and diabetes prevalence since 1980. Systematic analysis of health examination surveys and epidemiological studies with 370 country-years and 2.7 million participants. Lancet. Vol. 378. No. 9785. pp. 3140. DOI: 10.1016/S0140-6736(11)60679-X

DAVIS, C. - ABRAHAM, J. [2011]: The Socio-political Roots of Pharmaceutical Uncertainty in the Evaluation of "Innovative" Diabetes Drugs in the European Union and the US. Social Science and Medicine. Vol. 72. No. 9. pp. 1574-1581. DOI: 10.1016/j.socscimed.2011.02.035

DOKTORINFO KFT. [2013]: Bemutatkozás. Elérhető: http://www.doktorinfo.com/\# Letöltés dátuma: 2015. július 31 .

EGÉSZSÉGÜGYI STRATÉGIAI KUTATÓINTÉZET (ESKI) [2016]: Fogalomtár BNO. Elérhető: http://fogalomtar.eski.hu/index.php/BNO Letöltés dátuma: 2016. június 23 .

ELIXHAUSER, A. - STEINER, C. - HARRIS, D. R. - COFFEY, R. M. [1998]: Comorbidity measures for use with administrative data. Medical Care. Vol. 36. No. 1. pp. 8-27. DOI: 10.1097/00005650-199801000-00004

ELSEVIER [2016]: About Scopus. Elérhető: https://www.elsevier.com/solutions/scopus Letöltés dátuma: 2016. szeptember 05 . 
EGÉSZSÉGÜGYI NYILVÁNTARTÁSI ÉS KÉPZÉSI KÖZPONT (ENKK) [2015]:

Alap- és Müködési kereső. Elérhető: https://kereso.enkk.hu/ Letöltés dátuma: 2015. június 5 .

FRIEDMAN, S. R. - ARAL, S. [2001]: Social Networks, Risk-Potential Networks, Health, and Disease. Journal of Urban Health. Vol. 78. No. 3. pp. 411-418. DOI: $10.1093 /$ jurban/78.3.411

GREENHALGH, P. M. [1994]: Shared care for diabetes. A systematic review. Occasional paper (Royal College of General Practitioners). Vol. 67. i-viii. pp. $1-35$.

GRIFFIN S. [1998]: Diabetes care in general practice: meta-analysis of randomised control trial. British Medical Journal. Vol. 317. No. 7155. pp. 390-396.

de GROOT, V. - BECKERMAN, H. - LANKHORST, G. J. - BOUTER, L. M. [2003]: How to measure comorbidity: a critical review of available methods. Journal of Clinical Epidemiology. Vol. 56. No. 3. pp. 221-229. DOI: 10.1016/j.jclinepi.2003.09.002

HERBER, O. R. -SCHNEPP, W. - RIEGER, M. A. [2009]: Recruitment rates and reasons for community physicians' non-participation in an interdisciplinary intervention study on leg ulceration. BMC Medical Research Methodology. 9:61. DOI: $10.1186 / 1471-2288-9-61$

HICKMAN, M. - DRUMMOND, N. - GRIMSHAW, J. [1994]: A taxonomy for shared care for chronic disease. Journal of Public Health Medicine. Vol. 16. No. 4. pp. 447-454.

HIDVÉGI, T. [2013]: Teljes élet cukorbetegen. Magyar Diabetes Társaság. Elérhető: http://www.diabet.hu/upload/diabetes/document/Teljes_elet_cukorbetegen_be tegtaj_MDT_TELJES_20130930.pdf?web_id= Letöltés dátuma: 2015. augusztus 1 .

HOBBS, H. - WILSON, J. [2004]: Evaluation of the Alumni Program: a shared-care model for psychosis. Journal of Psychosocial Nursing and Mental Health Services. Vol. 42. No. 1. pp. 28-36. DOI: 10.3928/02793695-20040301-08 
HORVÁTH, J. [2015]: Quo vadis alapellátás? Medicalonline. Elérhető: http://www.medicalonline.hu/eu_gazdasag/cikk/quo_vadis_alapellatas Letöltés dátuma: 2016. június 5.

HUFNAGEL, L. - BROCKMANN, D. - GEISEL, T. [2004]: Forecast and control of epidemics in a globalized world. Proceedings of the National Academy of Sciences of the United States of America. Vol. 101. No. 42. pp. 15124-15129. DOI: 10.1073/pnas.0308344101

HUNYADI LÁSZLÓ - VITA LÁSZLÓ [2002]: Statisztika közgazdászoknak. Központi Statisztikai Hivatal, Budapest. pp. 255.

HUNTlEY, A. L. - JOHNSON, R. - PURDY, S. - VALDERAS, J. M. SALISBURY, C. [2012]: Measures of multimorbidity and morbidity burden for use in primary care and community settings: a systematic review and guide. Annals of Family Medicine. Vol. 10. No. 2. pp. 134-141. DOI: 10.1370/afm.1363

de JONGE, P. - ORMEL, J. - VAN DEN BRINK, R. H. - VAN MELLE, J. P. SPIJKERMAN, T. A. - KUIJPER, A. - VAN VELDHUISEN, D. J. - VAN DEN BERG, M. P. - HONIG, A. - CRIJNS, H. J. - SCHENE, A. H. [2006]: Symptom dimensions of depression following myocardial infarction and their relationship with somatic health status and cardiovascular prognosis. American Journal of Psychiatry. Vol. 163. No. 1. pp. 138-144. DOI: 10.1176/appi.ajp.163.1.138

KEATING, N. L. - ZASLAVSKY, A. M. - AYANIAN, J. Z. [1998]: Physicians' experiences and beliefs regarding informal consultation. The Journal of the American Medical Association. Vol. 280. No. 10. pp. 900-904.

KERESZTÚRI J. L. [2016]: Az egészségügyben megjelenő hálózatok és az egészségpolitika. Köz-gazdaság. Vol. 11. No. 1. pp. 169-180.

KIESZAK, S. M. - FLANDERS, W. D. - KOSINSKI, A. S. - SHIPP, C. C. - KARP, H. [1999]: A comparison of the Charlson comorbidity index derived from medical record data and administrative billing data. Journal of Clinical 
Epidemiology. Vol. 52. No. 2. pp. 137-142. DOI: 10.1016/s08954356(98)00154-1

KISS, N. [2016]: A hálózati teljesitmény javitása az egészségügyi rendszerben: a magyar egészségügyi szolgáltatások hálózati megközelitésü elemzése. Doktori $(\mathrm{PhD})$ értekezés, Budapesti Corvinus Egyetem, Gazdálkodástani Doktori Iskola. DOI 10.14267/phd.2016033

KLOVDAHL, A. S. - POTTERAT, J. J. - WOODHOUSE, D. E. - MUTH, J. B. MUTH, S. Q. - DARROW, W. W. [1994]: Social networks and infectious disease: the Colorado Springs Study. Social Science and Medicine. Vol. 38. No. 1. pp. 79-88. DOI: 10.1016/0277-9536(94)90302-6

KÖZPONTI STASZTIKAI HIVATAL (KSH) [2011a]: Egészségügyi Statisztikai Évkönyv, 2010. KSH, Budapest.

KSH [2011b]: Minden helység adata. Elérhető: https://www.google.hu/webhp?sourceid=chromeinstant\&ion=1\&espv=2\&ie=UTF-8\# Letöltés dátuma: 2014. szepteptember 5.

LANDON, B. E. - KEATING, N. L. - BARNETT, M. L. - ONNELA, J. P. - PAUL, S. O’MALLEY, A. J. - KEEGAN, T. - CHRISTAKIS, N. A. [2012]: Variation in patient-sharing networks of physicians across the United States. The Journal of the American Medical Association. Vol. 308. No. 3. pp. 265-273. DOI: 10.1001/jama.2012.7615

LARSEN M.L. - HØRDER, M. - MOGENSEN, E. F. [1990]: Effect of long-term monitoring of glycosylated haemoglobin levels in insulin-dependent diabetes mellitus. The New England Journal of Medicine. Vol. 323. No. 15. pp. 10211025. DOI: 10.1056/NEJM199010113231503

LEMIEUX-CHARLES, L. - MCGUIRE, W. L. [2006]: What do we know about health care team effectiveness? A review of the literature. Medical Care Research and Review. Vol. 63. No. 3. pp. 263-300. DOI: $10.1177 / 1077558706287003$ 
LI, B. - EVANS, D. - FARIS, P. - DEAN, S. - QUAN, H. [2008]: Risk adjustment performance of Charlson and Elixhauser comorbidities in ICD-9 and ICD-10 administrative databases. BMC Health Services Research. 8:12. DOI: $10.1186 / 1472-6963-8-12$

LINDSAY, G. - MCHUGH, F. - BROWN, M. - WHEATLEY, D. [1998]: Implementing Research in nurse-led care. Nursing Times. Vol. 94. No. 50. pp. 46-47.

LIX, L. M. - QUAIL, J. - FADAHUNSI, O. - TEARE, G. F. [2013]: Predictive performance of comorbidity measures in administrative databases for diabetes cohorts. BMC Health Services Research. 13:340. DOI: 10.1186/1472-6963-13340

LIX, L. - SMITH, M. - PITZ, M. - AHMED, R. - QUON, H. - GRIFFITH, J. TURNER, D. HONG, S. - PRIOR, H. - BANERJEE, A. - KOSEVA, I. KULBABA, C. [2016] Cancer Data Linkage in Manitoba: Expanding the Infrastructure for Research. MB. Manitoba Centre for Health Policy, Winnipeg.

LOMBARDO, M. - GOLDING, G. [2003]: Shared antenatal care: a regional perspective. Australian Family Physician. Vol. 32. No. 3. pp. 133-139.

LOU, B. - DE CIVITA, M. - EHRMANN FELDMANN, D. - BISSONAUTH, A. BERNATSKY, S. [2011]: Care partnerships between family physicians and rheumatologists. The Journal of Rheumatology. Vol. 38. No. 9. pp. 1981-1985. DOI: $10.3899 /$ jrheum.101150

LUBLÓY Á. - KERESZTÚRI J. L. - BENEDEK G. [2016a]: A gyógyszerkiadások és a betegek állapota a háziorvosi-szakorvosi kapcsolatok függvényében. Közgazdasági Szemle. Vol. 63. No. 6. pp. 697-714. DOI: 10.18414/ksz.2016.6.697

LUBLÓY Á. - KERESZTÚRI J. L. - BENEDEK G. [2016b]: Formal professional relationships between general practitioners and specialists in shared care: possible associations with patient health and pharmacy costs. Applied Health 
Economics and Health Policy. Vol. 14. No. 2. pp. 217-227. DOI: $10.1007 / \mathrm{s} 40258-015-0206-1$

LUBLÓY Á. - KERESZTÚRI J. L. - BENEDEK G. - VASTAG GY. [2016c]: Care to share: Impact of general practitioner-specialist collaborative structures on health care outcomes. In: Amitkumar Kakkad, Christian Rossetti (ed.) POMS 27th Annual conference: POMS 2016 Proceedings CD. Konferencia helye, ideje: Orlando, Amerikai Egyesült Államok, 2016.05.06-2016.05.09. Orlando: POMS, 2016. Paper 065-1529. 10 p. (ISBN:1-945072-01-6)

LUBLÓY, Á. - VÁRADI, K. [2013]: General practitioner-specialist relationships in shared care systems: insights from a review of the literature. Pannon Management Review. Vol. 2. No. 3. pp. 79-111.

LUKE, D. A. - HARRIS, J. K. [2007]: Network Analysis in Public Health: History, Methods, and Applications. Annual Review of Public Health. Vol. 28. pp. 6993. DOI: 10.1146/annurev.publhealth.28.021406.144132

MANEN, J. G. - KOREVAAR, J. C. - DEKKER, F. W. -BOESCHOTEN, E. W. BOSSUYT, P. M. - KREDIET, R. T. [2003]: Adjustment for comorbidity in studies on health status in ESRD patients: which comorbidity index to use? Journal of the American Society of Nephrology. Vol. 14. No. 2. pp. 478-485. DOI: 10.1097/01.ASN.0000043902.30577.C9

MARSHALL, M. N. [1998]: How well do general practitioners and hospital consultants work together? A qualitative study of cooperation and conflict within the medical profession. British Journal of General Practice. Vol. 48. No. 432. pp. 1379-1382.

MATTESICH, P. W. - MONSEY, B. [1992]: Collaboration: what makes it work. A review of research literature on factors influencing successful collaboration. (2nd ed.) Amherst H. Wilder Foundation, St. Paul, MA.

MCPHERSON, J. M. - SMITH-LOVIN, L. - COOK, J. M. [2001]: Birds of a Feather: Homophily in Social Networks. Annual Review of Sociology. Vol. 27. pp. 415444. DOI: 10.1146/annurev.soc.27.1.415 
MEYERS, J. L. - PARASURAMAN, S. - BELL, K. F. - GRAHAM, J. P. CANDRILLI, S. D. [2004]: The high-cost, type 2 diabetes mellitus patient: an analysis of managed care administrative data. Archives of Public Health. Vol. 72. 1:6. DOI: 10.1186/2049-3258-72-6.

MILLAR, J. - DRASIC, L. [2005]: A Report on Shared Care. Provincial Health Services Authority. Elérhető: http://www.phsa.ca/Documents/sharedcarereport2005.pdf. Letöltés dátuma: 2015. július 10 .

MOOREHEAD, R. (1995): Sharing care between allied health professional and general practitioners. Australian Family Physician. Vol. 24. No. 11. pp. 1985.

O'CONNOR, P. J. - RUSH, W. A. - SOLBERG, L. I. - WHITEBIRD, R. R. CRAIN, A. L. - DAVIDSON, G, - JOHNSON, P. E. - LOUIS, T. A. [2008]: Peer reviewed: variation in quality of diabetes care at the levels of patient, physician, and clinic. Preventing Chronic Disease. Vol. 5. 1:A15.

ORSZÁGOS EGÉSZSÉGBIZTOSÍTÁSI PÉNZTÁR (OEP) [2014]: Publikus gyógyszertörzs. Elérhető: http://www.oep.hu/pupha. Letöltés dátuma: 2014. április 10 .

OEP [2015]: Az OEP feladata, alaptevékenysége és hatásköre. Elérhető: http://www.oep.hu/felso_menu/rolunk/kozerdeku_adatok/tevekenysegre_muk odesre_vonatkozo_adatok/a_szerv_feladata_alaptevekenysege_es_hatarkore/ a_szerv_alaptevekenyege_feladata_es_hatarkore. Letöltés dátuma: 2015. január 20.

OEP [2016]: Járóbeteg Szakellátás. Elérhető: http://www.oep.hu/felso_menu/lakossagnak/ellatas_magyarorszagon/egeszse gugyi_ellatasok/jarobeteg_ellatas Letöltés dátuma: 2016. június 5.

OROSZ ÉVA. [2001]: Félúton vagy tévúton? Egészségügyünk félmúltja és az egészségpolitika alternatívái. Egészséges Magyarországért Egyesület, Budapest. 
PENG, D. X. - HEIM, G. R. - MALLICK, D. N. [2014]: Collaborative product development: The effect of project complexity on the use of information technology tools and new product development practices. Production and Operations Management. Vol. 23. No. 8. pp. 1421-1438. DOI: 10.1111/j.19375956.2012.01383.x

PHAM, H. H. - O’MALLEY, A. S. - BACH, P. B. - SAIONTZ-MARTINEZ, C. SCHRAG, D. [2009]: Primary care physicians' links to other physicians through Medicare patients: the scope of care coordination. Annals of Internal Medicine. Vol. 150. No. 4. pp. 236-242. DOI: 10.7326/0003-4819-150-4200902170-00004

POLLACK, C. E. - WEISSMAN, G. E. - LEMKE, K. W. - HUSSEY, P. S. WEINER, J. P. [2013]: Patient sharing among physicians and costs of care: a network analytic approach to care coordination using claims data. Journal of General Internal Medicine. Vol. 28. No. 3. pp. 459-465. DOI: 10.1007/s11606012-2104-7

POLLACK, C. E. - FRICK, K. D. - HERBERT, R. J. - BLACKFORD, A. L. NEVILlE, B. A. - WOLFF, A. C. - CARDUCCI, M. A. - EARLE, C. C. SNYDER, C. F. [2014]: It's who you know: patient-sharing, quality, and costs of cancer survivorship care. Journal of Cancer Survivorship, Vol. 8. No. 2. pp. 156-166. DOI: 10.1007/s11764-014-0349-3

POLLACK, C. E. - LEMKE, K. W. - ROBERTS, E. - WEINER, J. P. [2015]: Patient sharing and quality of care: measuring outcomes of care coordination using claims data. Medical Care. Vol. 53. No. 4. pp. 317-323. DOI: 10.1097/MLR.0000000000000319.

QUAIL, J. M. - LIX, L. M. - OSMAN, B. A. - TEARE, G. F. [2011]: Comparing comorbidity measures for predicting mortality and hospitalization in three population-based cohorts. BMC Health Services Research. Vol. 11. 1:146. DOI: $10.1186 / 1472-6963-11-146$

QUAN, H. - SUNDARARAJAN, V. - HALFON, P. - FONG, A. - BURNAND, B. - LUTHI, J. C. - SAUNDERS, L. D. - BECK, C. A. - FEASBY, T. E. - 
GHALI, W. A. [2005]: Coding algorithms for defining comorbidities in ICD9-CM and ICD-10 administrative data. Medical Care. Vol. 43. No. 11. pp. 1130-1139. DOI: 10.1097/01.mlr.0000182534.19832.83

QUAN, H. - LI, B. - COURIS, C. M. - FUSHIMI, K. - GRAHAM, P. - HIDER, P. - JANUEL, J. M. - SUNDARARAJAN, V. [2011]: Updating and validating the Charlson comorbidity index and score for risk adjustment in hospital discharge abstracts using data from 6 countries. American Journal of Epidemiology. Vol. 173. No. 6. pp. 676-682. DOI: 10.1093/aje/kwq433

RANMUTHUGALA, G. - PLUMB, J. J. - CUNNINGHAM, F. C. - GEORGIOU, A. - WESTBROOK J. I. - BRAITHWAITE, J. [2011]: How and why are communities of practice established in the healthcare sector? A systematic review of the literature. BMC Health Services Research. 11:273. DOI: 10.1186/1472-6963-11-273

REBOLlO, P. - ORTEGA, F. - BALTAR, J. M. - BADÍA, X. - ALVAREZ-UDE, F. - DÍAZ-CORTE, C. - NAVES, M. - NAVASCÚES, R. A. - UREÑA, A. ALVAREZ-GRANDE, J. [2000]: Health related quality of life (HRQOL) of kidney transplanted patients: Variables that influence it. Clinical Transplantation. Vol. 14. No. 3. pp. 199-207. DOI: 10.1034/j.13990012.2000.140304.x

RENDERS, C. M. - VALK, G. D. - GRIFFIN, S. J. - WAGNER, E. H. ASSENDELFT, W. J. [2001]: Interventions to improve the management of diabetes in primary care, outpatient, and community settings a systematic review. Diabetes Care. Vol. 24. No. 10. pp. 1821-1833.

RHOADES, S. A. [1993]: Herfindahl-Hirschman Index. Federal Reserve Bulletin, Vol. 79. pp. 188-189.

ROCHON, P. A. - KATZ, J. N. - MORROW, L. A. - MCGLINCHEY-BERROTH, R. - AHLQUIST, M. M. - SARKARATI, M. - MINAKER, K. L. [1996]. Comorbid illness is associated with survival and length of hospital stay in patients with chronic disability. A prospective comparison of three comorbidity 
indices. Medical Care. Vol. 34. No. 11. pp. 1093-1101. DOI: 10.1097/00005650-199611000-00004

SAN MARTIN-RODRIGUEZ, L. - BEAULIEU, M-D. - D'AMOUR, D. FERRADA-VIDELA, M. [2005]: The determinants of successful collaboration: a review of theoretical and empirical studies. Journal of Interprofessional Care. Vol. 19. Sup. 1. pp. 132-147. DOI:10.1080/13561820500082677

SHARABIANI, M. T. A. - AYLIN, P. - BOTTLE, A. [2012]: Systematic review of comorbidity indices for administrative data. Medical Care. Vol. 50. No. 12. pp. 1109-1118. DOI: 10.1097/MLR.0b013e31825f64d0

SMITH, S. M. - ALLWRIGHT, S. - O'DOWD, T. [2007]: Effectiveness of shared care across the interface between primary and specialty care in chronic disease management. Cochrane Database of Systematic Reviews, Vol. 3. No. CD004910. DOI: 10.1002/14651858.CD004910.pub2

SMITH, S. - CAMPBELL, N. [2004]: Provision of oncology services in remote rural areas: a Scottish perspective. European Journal of Cancer Care. Vol. 13. No. 2. pp. 185-192. DOI: 10.1111/j.1365-2354.2003.00472.x

SMITH, K. P. - CHRISTAKIS, N. A: [2008]: Social Networks and Health. Annual Review of Sociology. Vol. 34. pp. 405-429. DOI: 10.1146/annurev.soc.34.040507.134601

SMITH-DOERR, L.- POWELL, W. W. [2005]: Networks and economic life. In SMELSER, N. J. - SWEDBERG, R. (ed.) The Handbook of Economic Sociology. Russell Sage Foundation, New York. pp. 379-402. DOI: $10.1515 / 9781400835584.379$

UDDIN, S. - HOSSAIN, L. - KELAHER, M. [2011]: Effect of physician collaboration network on hospitalization cost and readmission rate. European Journal of Public Health, Vol. 22. No. 5. pp. 629-633. DOI: 10.1093/eurpub/ckr153 
UDDIN, S. - KELAHER, M. - PIRAVEENAN, M. [2015]: Impact of Physician Community Structure on Healthcare Outcomes. Studies In Health Technology And Informatics. Vol. 214. pp. 152-158. DOI: 10.3233/978-1-61499-558-6152

UDDIN, S. [2016]: Exploring the impact of different multi-level measures of physician communities in patient-centric care networks on healthcare outcomes: A multi-level regression approach. Scientific Reports. 6: 20222. DOI: $10.1038 /$ srep20222

VARDA, D. - SHOUP, J. A. - MILLER, S. [2012]: A systematic review of collaboration and network research in the public affairs literature: implications for public health practice and research. American Journal of Public Health. Vol. 102. No. 3. pp. 564-571. DOI: 10.2105/AJPH.2011.300286

VRIJHOEF, H. - DIEDERIKS, J. - SPREEUWENBERG, C. - WOFFENBUTTEL, B. - VAN WILDEREN, L. [2002]: The nurse specialist as a main care-giver for patients with type 2 diabetes in a primary care setting: effects on patient outcomes. International Journal of Nursing Studies. Vol. 39. No. 4. pp. 441451. DOI: 10.1016/s0020-7489(01)00046-3

VAN WALRAVEN, C. - OAKE, N. - JENNINGS, A. - FORSTER, A. J. [2010]: The association between continuity of care and outcomes: a systematic and critical review. Journal of Evaluation in Clinical Practice. Vol. 16. No. 5. pp. 947956. DOI: 10.1111/j.1365-2753.2009.01235.x

WENSING, M. - VAN DER EIJK, M. - KOETSENRUIJTER, J. - BLOEM, B. R. MUNNEKE, M. - FABER, M. [2011]: Connectedness of healthcare professionals involved in the treatment of patients with Parkinson's disease: a social networks study. Implementation Science. 6:67. DOI: 10.1186/17485908-6-67

WHITE, J. [2001]: Sharing the care of children with HIV infection. Nursing Standard. Vol. 15. No. 20. pp. 42-46. DOI: 10.7748/ns2001.01.15.20.42.c2979 
WHITE, T. [2010]: The Doctor's Handbook: Understanding the NHS. Radcliffe Publishing Ltd. Abington.

WHO (WORLD HEALTH ORGANIZATION) [2003]: Introduction to drug utilization research. In: Essential medicines and health products information portal: a World Health Organization resource. Elérhetö: http://apps.who.int/medicinedocs/pdf/s4876e/s4876e.pdf. Letöltés dátuma: 2014. április 10.

WORLD HEALTH ORGANIZATION (WHO) [1948]: Constitution. In Basic Documents. WHO, Genova.

WHO [2007]: The world health report 2007 - A safer future: global public health security in the 21 st century. Elérhetö: http://www.who.int/whr/2007/en/ Letöltés dátuma: 2015. augusztus 10.

WHO [2011]: Global status report on noncommunicable diseases (2010): Description of the global burden of NCDs, their risk factors and determinants. WHO Genf, Elérhető: http://www.who.int/nmh/publications/ncd_report2010/en/. Letöltés dátuma: 2014. április 10.

WHOCC (Collaborating Centre for Drug Statistics Methodology) [2016]: History. Elérhető: http://www.whocc.no/atc_ddd_methodology/history/ Letöltés dátuma: 2016. július 1 .

44/2004. (IV. 28.) ESzCsM rendelet az emberi felhasználásra kerülő gyógyszerek rendeléséről és kiadásáról

53/2007. (XII. 7.) EüM rendelet a gyógyszerrendeléshez használandó számítógépes program minősítésének szabályairól (2006. évi XCVIII. törvényhez)

1312/2016. (VI. 13.) Korm. határozat a központi hivatalok és a költségvetési szervi formában müködő minisztériumi háttérintézmények felülvizsgálatával kapcsolatos intézkedésekről 


\section{A témakörrel kapcsolatos saját publikációk jegyzéke}

\section{Publikációk referált szakmai folyóiratokban (magyar)}

LUBLÓY Á. - KERESZTÚRI J. L. - BENEDEK G. [2016]: A gyógyszerkiadások és a betegek állapota a háziorvosi-szakorvosi kapcsolatok függvényében. Közgazdasági Szemle. Vol. 63. No. 6. pp. 697-714.

KERESZTÚRI J. L. [2016]: Az egészségügyben megjelenő hálózatok és az egészségpolitika. Köz-gazdaság. Vol. 11. No. 1. pp. 169-180.

LUBLÓY Á. - KERESZTÚRI J. L. - BENEDEK G. [2015]: Az orvosok közötti kapcsolatok szerepe az új gyógyszerek elfogadásában. Közgazdasági Szemle. Vol. 62. No. 7-8. pp. 786-810.

KERESZTÚRI J. L. - LUBLÓY Á. - BENEDEK G. [2014]: Gyógyszerek terjedésének vizsgálata Cox-regresszióval. Statisztikai Szemle. Vol. 92. No. 8-9. pp. 792-819.

\section{Publikációk referált szakmai folyóiratokban (angol)}

LUBLÓY Á. - KERESZTÚRI J. L. - BENEDEK G. [2016]: Formal professional relationships between general practitioners and specialists in shared care: possible associations with patient health and pharmacy costs. Applied Health Economics and Health Policy. Vol. 14. No. 2. pp. 217-227.

KERESZTÚRI J. L. - LUBLÓY Á. - BENEDEK G. [2015]: Determinants of pharmaceutical innovation diffusion using the Cox model. Hungarian Statistical Review. Vol. 93. No. 19. pp. 47-66.

\section{Konferencia-kiadványok (magyar)}

KERESZTÚRI J. L. [2014]: Túlélési analízis eszköztárának és alkalmazási területeinek bemutatása. In: Schaub Anita, Szabó István (ed.): III. Interdiszciplináris Doktorandusz Konferencia 2014. Konferencia helye, ideje: Pécs, Magyarország, 2014.04.15. (ISBN:978-963-642-741-2) 
KERESZTÚRI J. L. - LUBLÓY Á. - BENEDEK G. [2014]: Cukorbetegség kezelésére újonnan fejlesztett készítmények terjedésének vizsgálata. In: Rajnai Zoltán, Fregan Beatrix (ed.). Az 5. Báthory-Brassai Konferencia tanulmánykötetei. Konferencia helye, ideje: Budapest, Magyarország, 2014.05.21-2014.05.22. Budapest: Óbudai Egyetem Biztonságtudományi Doktori Iskola, 2014. pp. 265-269. (ISBN:978-615-5460-38-8)

KERESZTÚRI J. L. - LUBLÓY Á. - BENEDEK G. [2014]: Magyarországra bevezetett két új gyógyszer terjedésére ható tényezők azonosítása Cox modellel In: Csiszár Imre, Kőmíves Péter Miklós (ed.). Tavaszi Szél 2014 Konferenciakötet I. Közgazdaságtudomány. Konferencia helye, ideje: Debrecen, Magyarország, 2014.03.21-2014.03.23. Debrecen: Doktoranduszok Országos Szövetsége, 2014. pp. 276-284. (ISBN:978-96389560-5-7)

KERESZTÚRI J. L. - LUBLÓY Á. - BENEDEK G. [2014]: Társadalmi hálózatok vizsgálata újonnan bevezetett gyógyszerek esetében. In: Lukovics Miklós, Zuti Bence (ed.). A területi fejlődés dilemmái. Konferencia helye, ideje: Kecskemét, Magyarország, 2014.06.12 Szeged: Szegedi Tudományegyetem Gazdaságtudományi Kar, 2014. pp. 169-179. (ISBN:978-963-306-344-6)

\section{Konferencia-kiadványok (angol)}

LUBLÓY Á. - KERESZTÚRI J. L. - BENEDEK G. - VASTAG GY. [2016]: Care to share: Impact of general practitioner-specialist collaborative structures on health care outcomes. In: Amitkumar Kakkad, Christian Rossetti (ed.) POMS 27th Annual conference: POMS 2016 Proceedings CD. Konferencia helye, ideje: Orlando, Amerikai Egyesült Államok, 2016.05.06-2016.05.09. Orlando: POMS, 2016. Paper 065-1529. 10 p. (ISBN:1-945072-01-6)

\section{Konferencia-előadások (magyar)}

KERESZTÚRI J. L. [2015]: Háziorvosok és diabetológus szakorvosok együttmüködésének hatása a betegek egészségi állapotára és a 
gyógyszerköltségekre. Magyar Diabetes Társaság XXIII. Kongresszusa. Budapest, 2015. május 14-16.

\section{Mühelytanulmányok}

LUBLÓY Á. - KERESZTÚRI J. L. - BENEDEK G. [2015]: Formal professional relationships between general practitioners and specialists: possible associations with patient health and pharmacy costs. Corvinus Economics Papers 4/2015. Budapesti Corvinus Egyetem.

LUBLÓY Á. - KERESZTÚRI J. L. - BENEDEK G. [2014]: Determinants of pharmaceutical innovation diffusion: social contagion and prescribing characteristics. Corvinus Economics Papers 17/2014. Budapesti Corvinus Egyetem. 